\title{
Color Architecture Landscape in the Ancient Mediterranean World Mural Painting, Analysis and Comparison: Mutual Influence and Contamination through the Mediterranean Sea
}

\author{
By Patrizia Falzone
}

The basic themes are: A - The building, at architectural, building and urban levels, in the relationship between architectural, chromatic and decorative values. $B$ - The theme of the landscape and of the environment, the built in relationship with urban spaces and territory. $C$ - The theme, most important, about the mutual influences and contamination - colours and decorative types resulting from dense web of relationships of populations across the Mediterranean Sea. Common to the themes is the very important aspect of the identification of places in relation to their prevailing colour components, or to the types of decorative and chromatic devices. If the interest of the writer for the color is developed in a wide span of time, the study of architecturalchromatic-decorative elements of the facades of historic buildings from the Middle Ages to the nineteenth century, here however they retrace the origins and history, to prove, both from what remains both the most from the ancient and authoritative sources, that this building and decorative practice, the decorative surface finishing function, either with exterior and interior architecture, is an integral part of architecture that has always been. It is the continuation of a very ancient and widespread practice in many countries bordering the Mediterranean, as in the Egyptian world, whose origins precede the fourth millennium BC, and in the neighboring cultures, Syrian-Palestinian and Phoenician. The same is found in the Greek and pre-Hellenic world, from what remains at Knossos in Crete, at Santorini and in Greece, as documented by the architectural type color treatment, pretending colored marble, the portion of the wall, rebuilt, kept at museum of Pella (Macedonia), referring to the $4^{\text {th }}$ century BC, and the reign of Philip II.

\section{Introduction}

The theme of re-built environment and landscape colour component in the report with the form and the characters both buildings of urban spaces, is located within a wider and complex cognitive architecture method. A method which seeks to bring in evidence that still exists of colour components, a significant time and identity, not only architecture, but also places in their natural components: mainly in order to redesign the restoration and enhancement of this heritage. Two are the major fundamental themes in the subject matter:

*Professor, University of Genoa, Italy. 
- The theme at architectural, building and urban levels of the built in relation to the chromatic/decorative values of its surfaces: vertical and horizontal.

- Landscape and environment theme, regarding the color interaction of the built with immediate spaces of space, with large urban spaces, and above all with the shape and character of the surrounding territory; moreover, the impact of the built in the environment. ${ }^{1}$

Common to both themes is the aspect, very important, of the identification of places in relation to the prevailing chromatic components (both the natural element and buildings elements), or to the types of decoration. Therefore, knowledge (and survey) prospects in all their components, including decorative features, colors, type and material of any kind of technologies, constitute a fundamental element of historical-critical documentation and complete knowledge of the buildings, especially for the purposes of protection, enhancement and conservation.

But what appeared fundamental to a real deep knowledge of color component in the ancient Mediterranean world, which will merge then that of the centuries to come, especially in the "modern" era, is the study of reciprocal influences and contamination - materials, colors and decorative types - deriving from the dense Web of relationships of populations across the Mediterranean Sea since ancient times, for both political and commercial reasons. This in order to understand how and why decorative elements and behaviors occur in countries far away and different cultures, and what are the directions of development of the various attitudes.

Indeed, since the dawn of time, man has used to build the buildings, in each region/country, and especially in the Mediterranean, technology, materials, and their colors:

- primarily stone and/or brickwork (structural or coating), monochromatic or bicromous, horizontal or design, geometric, or decorative;

- simple colours, on all or part of the facade;

- decorative and geometric motifs painted, as carpets hanging on the walls, up to real wall paintings on the exterior and internal facades (and first on rock, both inside and outside, from prehistory to churches and monasteries excavated in the rock, as well as Cappadocia, or MateraItaly);

- ceramic coatings, monochromatic, polychrome, both exterior and interior (domes, roof, exterior walls and interiors, doors and urban enclosures, garden furniture), typical of the eastern countries but diffused mainly in southern Italy, or in all places reached by the Mediterranean Sea;

- cobblestone mosaics, monochromes, bicromes or polychromes, from the earliest times, in the finest types of Pella (Macedonia), and throughout Greece, and then regular mosaics, widespread in Rome, in the Byzantine

1. P. Falzone, "Colore Architettura Ambiente. Temi e Problematiche," in Colore Architettura Ambiente (ed.) P. Falzone (Rome: KAPPA, 2008). 
world, and everywhere in Italy, up to the last few centuries, from the simplest and most essential forms (cobbled in the streets), to the richest and most decorative ones, geometries, scenes, figures, and architectural elements.

A use of color through materials with chromatic values - stones, marbles, pebbles, colored plaster, which varies from that constructive-decorative (ceramic elements to cover domes and roofs - walls-floors, or mosaics) to actual fresco painted facades decorated with architectural motifs, with or without figures or figurative scenes, or with decorative geometric, floral, symbolic and heraldic motifs.

So, if the interest for color, of those who write, has grown into a wide span of time in the study of chromatic-decorative-architectural facades of historical buildings in Italy and in Europe, and particularly in the study of façades painted with fresco, from the Middle Ages to the nineteenth century, here we want to retrace the origins and history. To demonstrate, both from what remains, both in reference to the most ancient authoritative sources and from modern discoveries, based on surface decorative finishes, (both external and internal) of architecture, is an integral part of the architecture since ever, aimed at the architectural facies, as well as to express political, religious, social content. What prompts you to reconsider the Mediterranean world and Middle East, the cradle of our civilization.

This examination of the Mediterranean world had already begun regarding the specific case of study of stone materials constituting the surfaces of architecture, especially of the exteriors, from study ${ }^{2}$ which had emerged already a not unimportant concatenation of decorative mode in the Mediterranean basin.

\section{State of the Art}

Regarding this issue, it must be said that there are no specific extensive insights into the timeline, because existing studies typically face cultural, architectural and artistic scopes separately in each country, or of individual historical periods. Moreover, studies in the history of art and architecture take into consideration aspects or particularly significant artifacts usually under the artistic aspect. Therefore, it seemed interesting to try to delineate an excursus on the topic, as much as schematic e concise, us timeline anyway, in different cultures, characters and using decorative types, materials and colors in architecture.

But, even before that, the proposed theme, in addition to the recognition of the artifacts, and their comparison in time and in the various geographical areas, requires the recognition of historical, political, economic, as well as

2. Falzone, "In Tema di Paramenti e Rivestimenti del Costruito. Il Motivo a Fasce Bicrome e Policrome. Influssi e Contaminazioni Attraverso il Bacino Mediterraneo," in Colore e Colorimetria: Contributi Multidisciplinari (ed.) M. Rossi and A. Siniscalco (Firenze: Maggioli Editore, 2013), 504-520. 
artistic and archaeological events, of different civilizations and cultural areas in the Mediterranean basin. Recognition that offers a punctual reference to the connections, even the most distant, of typologies, of decorative apparatuses, of stylistic and representative modalities, of the artefacts object of this study

\section{Civilization of the Ancient Mediterranean World: Influences and Relationships}

The numerous and even more recent archaeological discoveries in mainland Greece, in Crete and in the Cyclades, have enriched and sometimes modified the knowledge on the Aegean civilization from the end of the Neolithic Age to the Bronze Age and those related to the initial phase of the Iron Age. This has also highlighted the important role that the different cultures present in the Aegean territories (Aegean civilization that includes the Cretan, Cycladic, Mycenaean civilizations), have assumed in the process of formation and development of the successive Protogeometric and Geometric Age, in which the process of integration between them takes place, as premise to the creation of the Greek civilization. But not only.

The latest research ${ }^{3}$ aims to better understand the Aegean cultural "facies", and the individual Cretan, Cycladic, and Mycenaean civilizations, from their farther past, and their reciprocal influences. In addition, in order to underline the existence of close relations between the Aegean and Middle Eastern peoples, although they were sometimes separated by significant geographic distances, the possible cultural referents outside the Aegean world are also considered, in Mediterranean or Middle Eastern countries.

The beginning of the process of formation of the Aegean civilization appears very marked by the strong cultural change of the populations of the Greek peninsula and of the Aegean islands, in relation to the contact with the Anatolian civilization, since the beginning of the III Millennium, with the knowledge of use of metals (gold, silver and copper), and of the megaron as a housing unit.

In the first half of the same millennium, the extension of their artistic repertoire and the modification of traditional customs and habits are due to the interweaving of commercial relations with the Middle Eastern populations.

In the last centuries of the III Millennio these effects are more evident in the Aegean territories, and, in particular, in the island of Crete, thanks to its favorable geographical position and the ability of its population in the art of sailing, which allows to establish flourishing commercial activities with the Mediterranean countries due to the supply of refined handmade bronze objects. The presence of arioeuropean groups that settle in the Aegean territories during the period of transition between the III and the II Millennium, which despite the sequence of disastrous seismic events, give life and vital signs in the Cretan society.

3. G. Ciotta, Architetture Egee. Momenti di Culture Variegate e Premesse alla Civiltà Greca (Milano: Franco Angeli, 2013). 
Crete, after the destruction of the main palatial centers around the 1700 A.C., for reasons still not completely clarified, crosses in the neopalatial period (from the end of the XVII C. until the first decades of the XV century B.C.), a period of great political, artistic and economic splendour, assuming the role of the main pole of cultural irradiation not only of the Aegean, but also of the Mediterranean. ${ }^{4}$

In this phase Cretan merchants resume and intensify trade relations both with Egypt (where they could freely exercise their business with the consensus of the Pharaoh), and with Syria (in whose coastal range they had bases). In this period there are osmosis of knowledge and relationships also with artistic and cultural aspects, as well as building, with architectures characterized by a great monumentality, perhaps due to oriental suggestions.

The monumentality is also addressed to the sanctuaries already existing on the peaks, in a prominent position, with the addition of terraces and new structures, which accentuate the role of the place people faith devotion, and that of territorial control.

The renovation also extends to the Cyclades islands but, if the Cycladic continue to integrate the iconographic schemes in their architectural and decorative language, the decorative parties and the constructive systems derived from the Cretan architecture. The elegant wall decorations of Akrotiri in the island of Thera (Santorini), still preserved, show to be the highest, original and valuable expression of what is produced in this sector in the Aegean world.

The birth, between the end of the XV and the beginning of the 14th century, of the complex Mycenaean palatial system, with its policy of control of the transmarines of metal supply, determines the ascent of Mycenae to the rank of great political center of the Argolide and of Greece, as well as a reference pole for the populations of the regions on Pontus Euxine/Black Sea (rich in mineral deposits), for those of Cyprus, of Western Anatolia, of Troad, of the Balkans, of the Iberian Peninsula and of southern Italy, and Sicily. The Mycenaean invade the island of Crete and the Cyclades around 1425 B.C., becoming undisputed masters of the Mediterranean, even for internal conflicts or weakening of the central Cretan power caused by the earthquake, referring to the period 1550/1530, but they transpose the Cretan and Cycladic customs, bringing together in the new state unit, Mycenaean, the motifs derived from the traditions of the three geographical areas. Moreover, in the last decades of the $13^{\text {th }}$ century B.C., the disasters for the seismic events and the threats of the Balkan peoples so weaken the palatial Mycenaean system that in the beginning of the XII century, there is the collapse of the great Mycenaean civilization.

\section{Methodology}

The method to reconstruct this cultural and architectural heritage, even from the smallest signals and traces of colors in architecture, use:

4. Ibid, 10-14. 
- the more general bibliography, art and architecture, about individual countries;

- the existing specific bibliography;

- archives, both in Italy and abroad: of the Superintendencies, the historical archives of the municipalities and of the State Archives;

- museums and how to preserve these paintings or wall coverings, or documents;

- travel and the project visits undertaken personally over time, with specific attention to this aspect, and related documents, to build a path of color in architecture behaviors in the countries of the Mediterranean basin, from its origins and over time: buildings, urban episodes, cities, territories and historical environments in general.

Critical to this investigation is not only what is still preserved almost everywhere in the Mediterranean world, in the countries faced to it, but also the pictorial production of representation of built by artists and scholars of the past; especially the one that derives mainly from the documentation of the Academy of France in Rome pensionnaires of the nineteenth century. In addition, since February of 1845, the Académie des Beaux-Arts in Paris that was the Academy's pensionnaires Villa Medici in Rome was allowed to spend a year in Athens to prepare or explore the themes of their mails and packages. So, by 1846 , the École Française of Athens, founded in 1846, welcomed french pensionnaires who attended numerous. ${ }^{5}$

They, besides the measured survey and the study of single building, represented in the orthogonal projections, in color, designed and/or painted images even with high landscape value regarding ancient artifacts perception, and the relation between buildings/cities and the territory. Basically even as they draw and paint scholars, archaeologists, historians, artists, or just fans, both English and Germans, Italians, French, giving an important contribution in this direction, starting from the end of the eighteenth century to the early $20^{\text {th }}$ century, ${ }^{6}$ what the huge corpus of watercolors by David Roberts on Egypt.

5. M. F. Billot, Recherches aux XVIIIe et XIXe Siècles sur la Polychromie de l'Architecture Grecque, in Paris - Rome - Athènes. Le Voyage en Grèce des Architectes Francais aux XIXe Siècle (Paris: Catalogo della Mostra, 1982).

6. A. C. Quatremere de Quincy, Le Jupiter Olympien ou de l'Art de la Sculpture Antique, Considéré sous un Nouveau Point de Vue; Ouvrage qui Comprend un Essai sur le Gout de la Sculpture Polychrome (Paris: Firmin Didot, 1815); J. Hittorf, De l'Architecture Polychrome chez les Grecs, ou Restitution Complete du Temple d'Empedocle, dans l'Acropole de Selinunte (Paris: Firmin Didot, 1851); F. Kugler, Uber die Polychromie der Griechischen Architektur und Sculptur, und ihre Grenzen (Berlin: G. Gropius, 1835); G. Semper, "The Origin of Polychromy in Architecture," in An Apology for the Coloring of the Greek Court (ed.) J. Owen (London: Crystal Palace Library and Bradbury \& Evans, 1854). 


\section{Color Behaviors in Architecture in the Countries of the Mediterranean Basin}

With respect to two levels, A and B, for reasons of space the theme is here considered together in every age and country, except in the case of Greece, which is particularly significant for the presence of the corpus of drawings in color, very nourished even in environmental, by the pensionnaries of France, which already expresses awareness of the importance of this aspect, in the wake of what has been done by David Roberts (1796-1864) in Egypt, Nubia and the Holy Land.

The use of color in architecture is very ancient and widespread practice, developing in many countries overlooking the Mediterranean: from Egyptian world, whose origins predate the $4^{\text {th }}$ millennium $\mathrm{BC}$, and from neighboring cultures, Syro-Palestinian and Phoenician, to that, even more to the east, Mesopotamian, very articulate, to the Aegean, Cretan, Cycladic and Mycenaean, flourished during the $3^{\text {th }}$ and $2^{\text {th }}$ millennium $\mathrm{BC}$, in the area of the eastern Mediterranean basin, with its two main centers of development, the island of Crete, in the Aegean sea, and the city of Mycenae in the Argolis. In Central Italy the culture of the Etruscan world already use widely this practice, as witnessed by the $11^{\text {th }}$ century $\mathrm{BC}$ in the complexes rich graves painted equipment of the tombs of Cerveteri and Tarquinia: pictorial culture which flows then in Roman, with the overlap of the Romans to the Etruscan civilization.

\section{Colors and Decorative Features in the Egyptian World: Use and Characters}

Already in the Egyptian world, one of the oldest civilizations before the $4^{\text {th }}$ millennium BC, color and decoration components appear important and widespread, in relation to the strong symbolic content than depicted in wall paintings (both political and religious issues), as well as in neighboring cultures (Syro-Palestine and Phoenicia), with which a remarkable artistic exchange interweaves over the centuries.

This civilization develops into a long period of time, from the archaic period or Tinita (3150-2700 BC), until the late period (672-343 BC), producing constantly carved, painted, or sculpted devices and paintings, with very lively colors, on the external and internal walls of temples, palaces on the and especially with strong religious and symbolic meanings in the many tombs.

The tablet of King Narmer (or Menes, lived around 3125-2850 B.C.), Pharaoh of the Egyptian of the first dynasty, introduces you to the wonderful world of rich Egyptian mythology, and is one of the oldest documents of the first Egyptian Kingdom, the Thinita Kingdom (3000-2778 B.C.). In this realm writing was born, but mostly were defined the iconography of deities, which will remain unchanged: Horus, the God of the Sun, depicted as a Falcon; the snake, protector of the King, as the Stele of King snake in the Louvre in Paris, and numerous other sacred animals like the ox, cat, crocodile, scrabble.

With the third dynasty, which begins the Old Kingdom (2778-2220), and moves the capital to Memphis, founded around 3000 on the delta of the Nile by 
the first pharaoh Menes, the city develops with grandiose monuments, and sculptures.

The five centuries of the new Kingdom (1580-1085 B.C.) are the richest of artistic works in the history of Egypt, especially in the field of wall paintings. Are elaborate pictorial and plastics shapes rich, varied, imaginative, in some cases by releasing figures from usual fixity and rigidity, as in the grandiose funerary temples arose around Thebes that replace the pyramids. The temple of Queen Hatshepsut at Deir-el-Bahri is a single episode of monochrome architecture-environment, with large sloping terraces adjoining the rock, made in the same color, creating a unique among the natural and built context, and an insertion in the environment of great visual effect.

In bigger temples, tombs and in the most important buildings dominating the decorative component - of design and chromatic - always strongly religious and symbolic celebration of the figure of the Pharaoh: Temple of Thutmose III in Karnak, dedicated to the god Amun-Re; of Amenofis III in Luxor, dedicated to the divine triad Amon-Mut-Khonsu, terminated later by Ramesses II, with extensive decorations on relief and long colonnades.

The highly engraved drawing of the outlines, with a strong chiaroscuro effect (temples of Edfu, Philae), used to reinforce and emphasize the characters, animals and objects of the narration, is very widely used.

The iconographic repertory consists mainly in ceremonial scenes, with the Pharaoh, the gods, court characters, sacred animals and plants, neatly composed at times with hieroglyphs and religious symbols, as in the funeral chapels of Thutmose III and Haremhad (Figure 1). Figures and scenes, decorations, animals, and hieroglyphics operate a scan of the surfaces, and then space, and a dimensional reference, including through the presence of the human figure: thus the painted decoration creates architecture, especially when this is very simple.
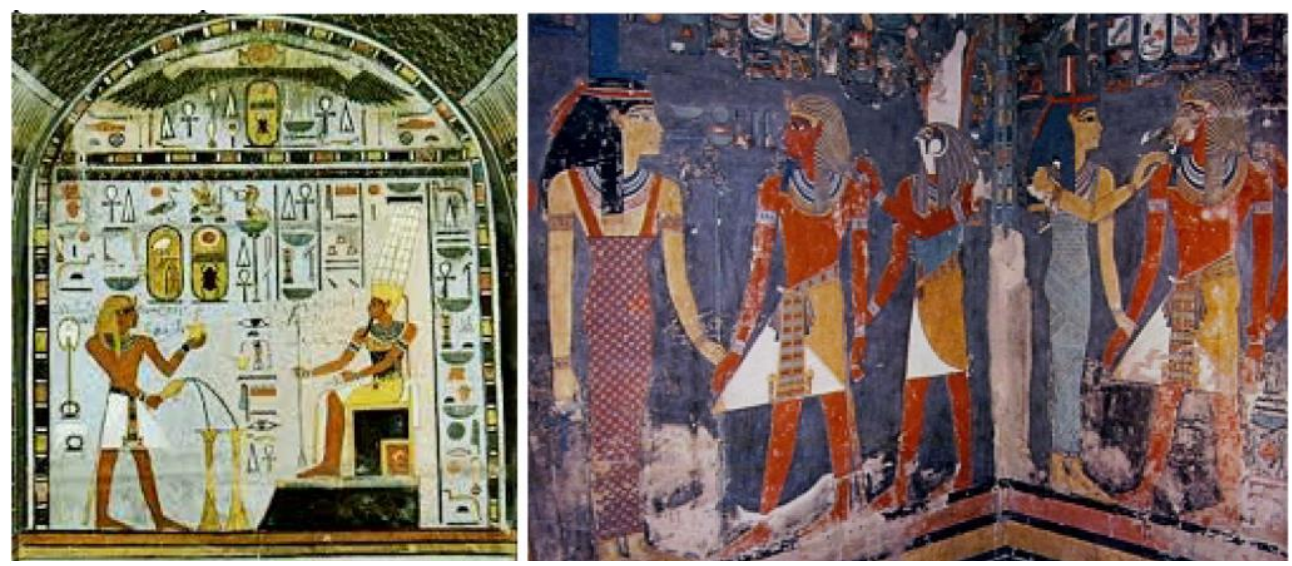

Figure 1. (Left) Funeral Chapel of Thutmose III. Fresco of the Back Wall (Right) Tomb of Haremhad. Wall Fresco. Sakkara. Kings' Valley

Source: F. Negri Arnoldi, Storia dell'Arte (Milan: Fabbri Editori, 1968).

In the Temple of Hator at Dendera the duotone vault, with a bright blue background, presents a procession of relief figures, of earth color of light shade, enclosed within the figure of the goddess Nut, with the solar disk. 
But the façade of the Temple also shows the presence of bright and vivid colors in the suggestive watercolors of David Roberts, in the frieze and capitals formed by the heads of the goddess Hator, with a rich polychrome hairstyle in bright colors (Figure 2, on the right, below).

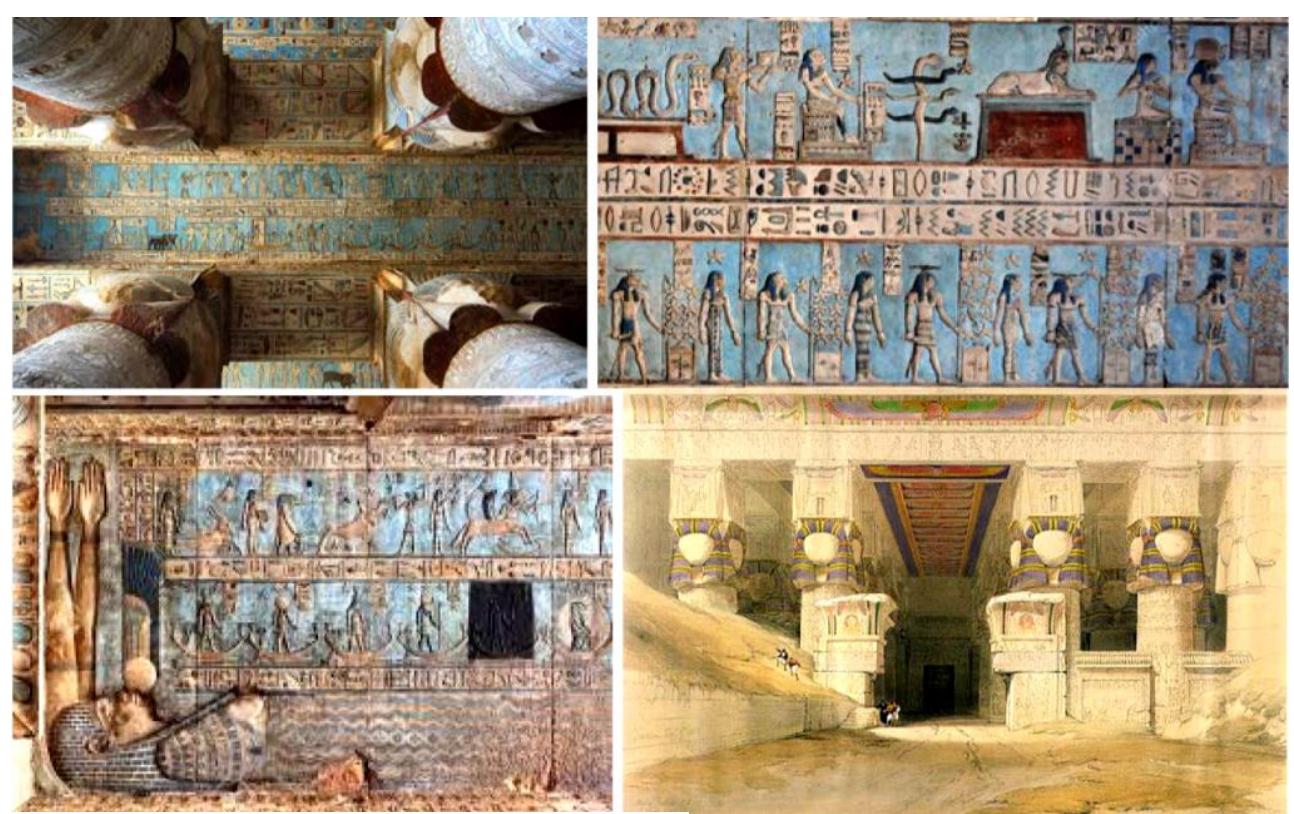

Figure 2. Temple of Hathor at Dendera

Source: Egitto, vol. I (Milan: Fabbri Editors, 1997-98); https://tinyurl.com/yd2bfum2.

Thus, in the exterior and interior of the grandiose temples the decoration marks everything, from walls to columns, trabeation and vaults, they almost always assimilated to the vault of heaven, like the case of the Temple of the goddess Hathor at Dendera, and of the great tombs (Tomb of Ramesses II, Tomb of Ramesses V and VI, Nefertari's Tomb, ...) with the iconography of the goddess Nut, Lady of the sky, which binds all the time in one paginates, curving arc to embrace the whole time on the three sides.

Few are the colors used, but always very lively: red, ochre, light blue, blue, then white, green, black.

At the same time there is also the presence of a stylistic-decorative typology with a strong naturalistic component, and more joyous, defined by softer and rounder lines, and more delicate colors, strongly decorative, proves instead with evidence linking with the Cycladic and Cretan civilization, deriving from the dense commercial network existing between the two countries, as mentioned above, in art forms but also in subjects, representing episodes of life: hunting, parties, dances and domestic life, such as the most lively paintings perhaps coming from the Tomb of Nebamon (Figure 3).

The comparison between the frescoes of Akrotiri in Santorini and Knossos in Crete shows this strong parallelism, especially in reference to the joyful component of a life in total immersion in the natural environment (Figure 4). 


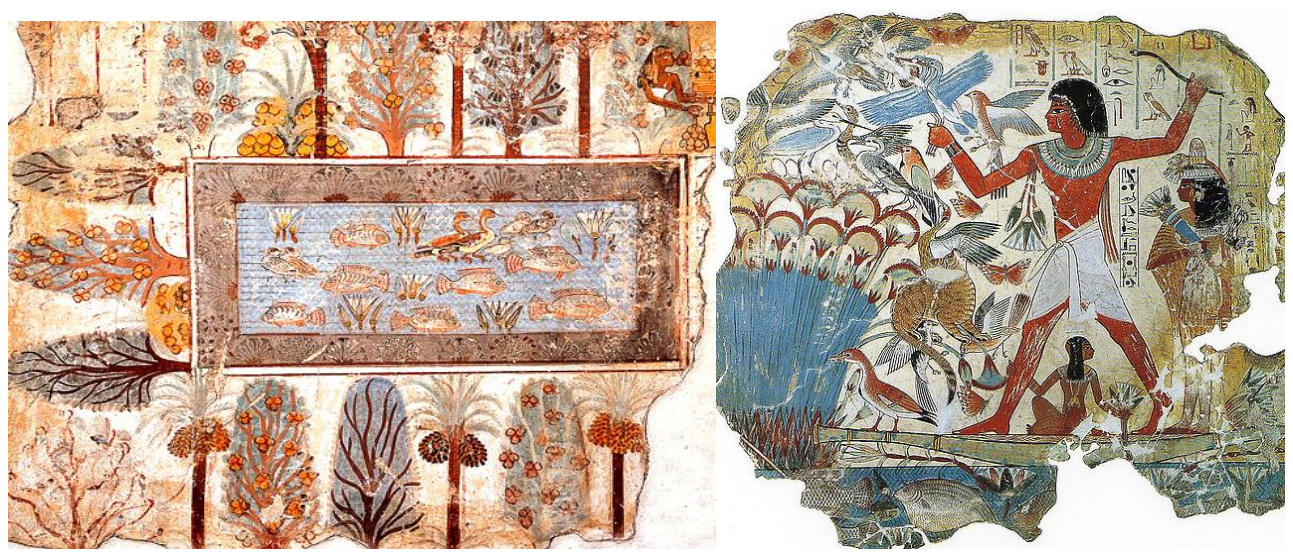

Figure 3. The Garden of the Deceased and Hunting in the Marsh. From the Tomb of Nebamun, perhaps Frescoes in the British Museum Source: Negri Arnoldi, Storia dell'Arte, 1968.

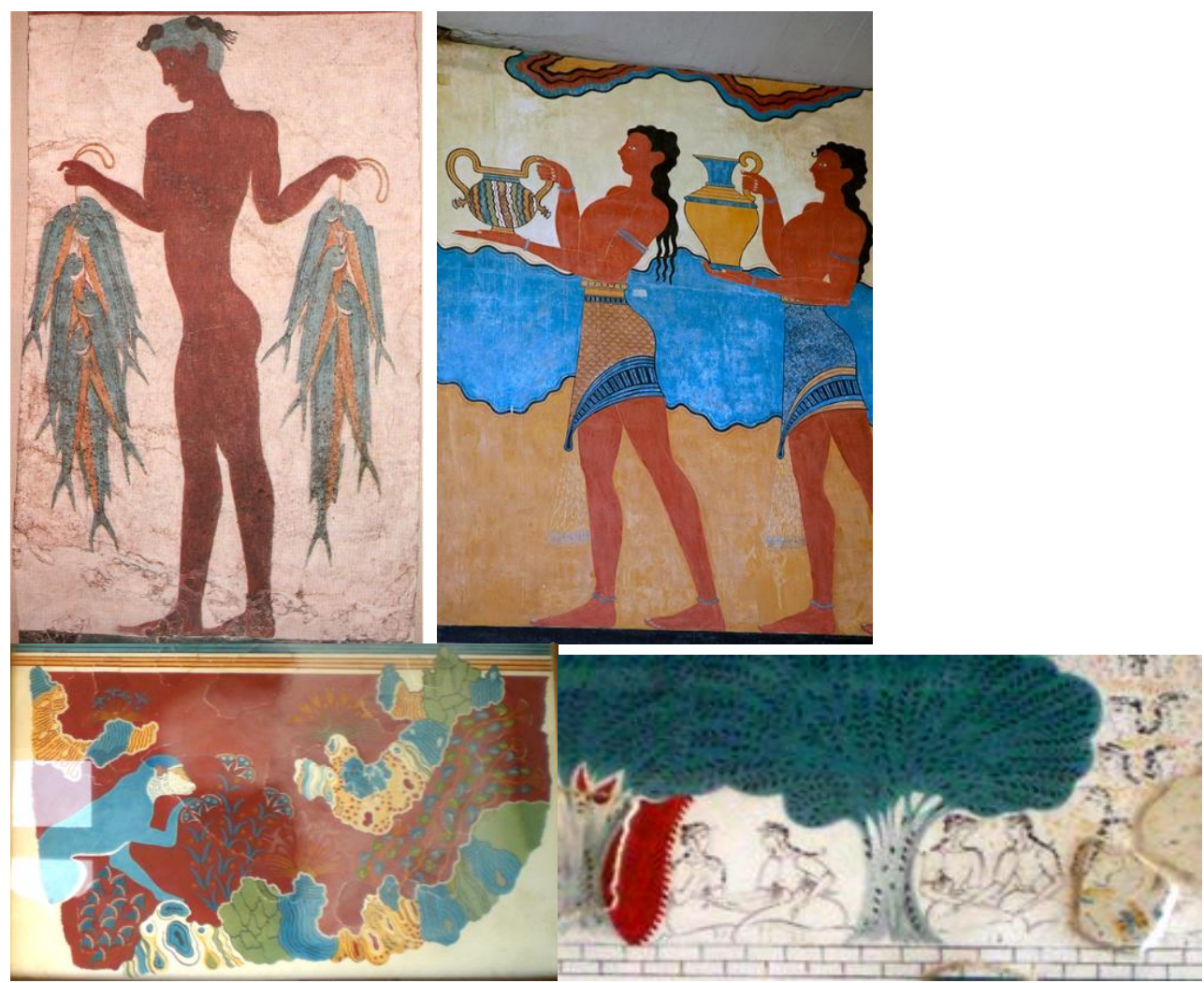

Figure 4. (Left and up) Nude of a Young Fisherman, with the Haircut of Libyan Origin, Akrotiri, Fresco from the Western House (Right and up, Below) from the Palace of Knossos, Ritual Procession; Portion of a Fresco with a Blue Monkey in a Garden; Fresco of the Sacred Wood and Dance

Source: (left and up) Y. Papaioannou and Y. Skouroyannis, Santorini (Athens: Ed. Ben. Issaias \& Co, 1977); Iraklion Museum. Photographs by the Author.

Returning to the grave paintings, in the King Tut's tomb is made with the classic essential interior painted architecture, consisting of a base and range from full-height walls punctuated by the impressive figure of Pharaoh with the 
gods and, in the hallway, by the two guardians - big dogs/Anubis-, with the vault all minutely written in hieroglyphs (Figure 5).
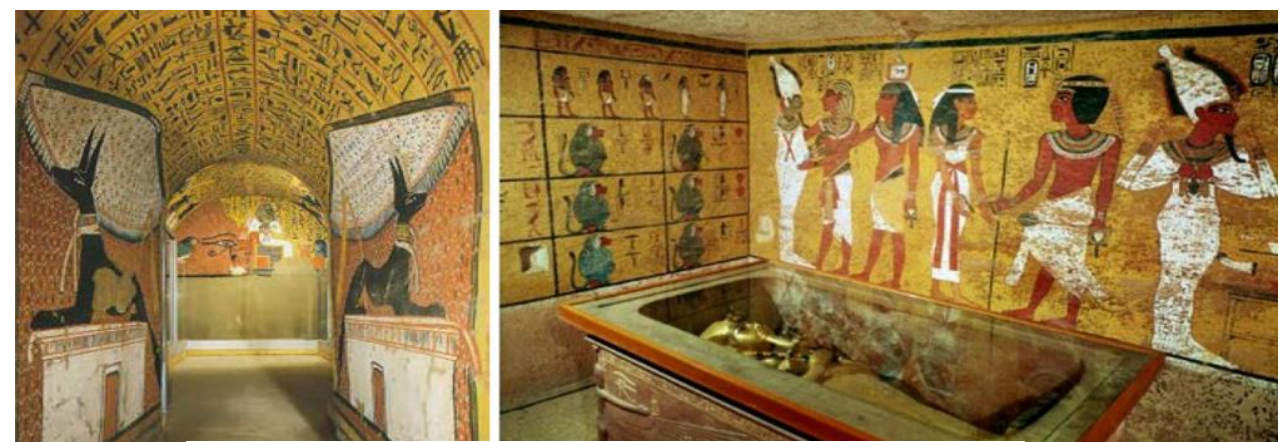

Figure 5. King Tut's Tomb. Entrance Hall and Funeral Hall Source: https://tinyurl.com/yd2bfum2.

With the $19^{\text {th }}$ dynasty, of Ramessidi, in addition to the extensions of Karnak and Luxor are born new temples carved into the rock, with face characterized by giant statues of Pharaohs and extensive bas-reliefs, as the two temples of Abu Simbel (Figure 6), that still refer to the unity between architecture-environment, of great landscape value, both for the continuity of materials and that of color, meanwhile does not change, in the Interior, the use of the painting, according to represent Pharoah and religious scenes or symbolic.
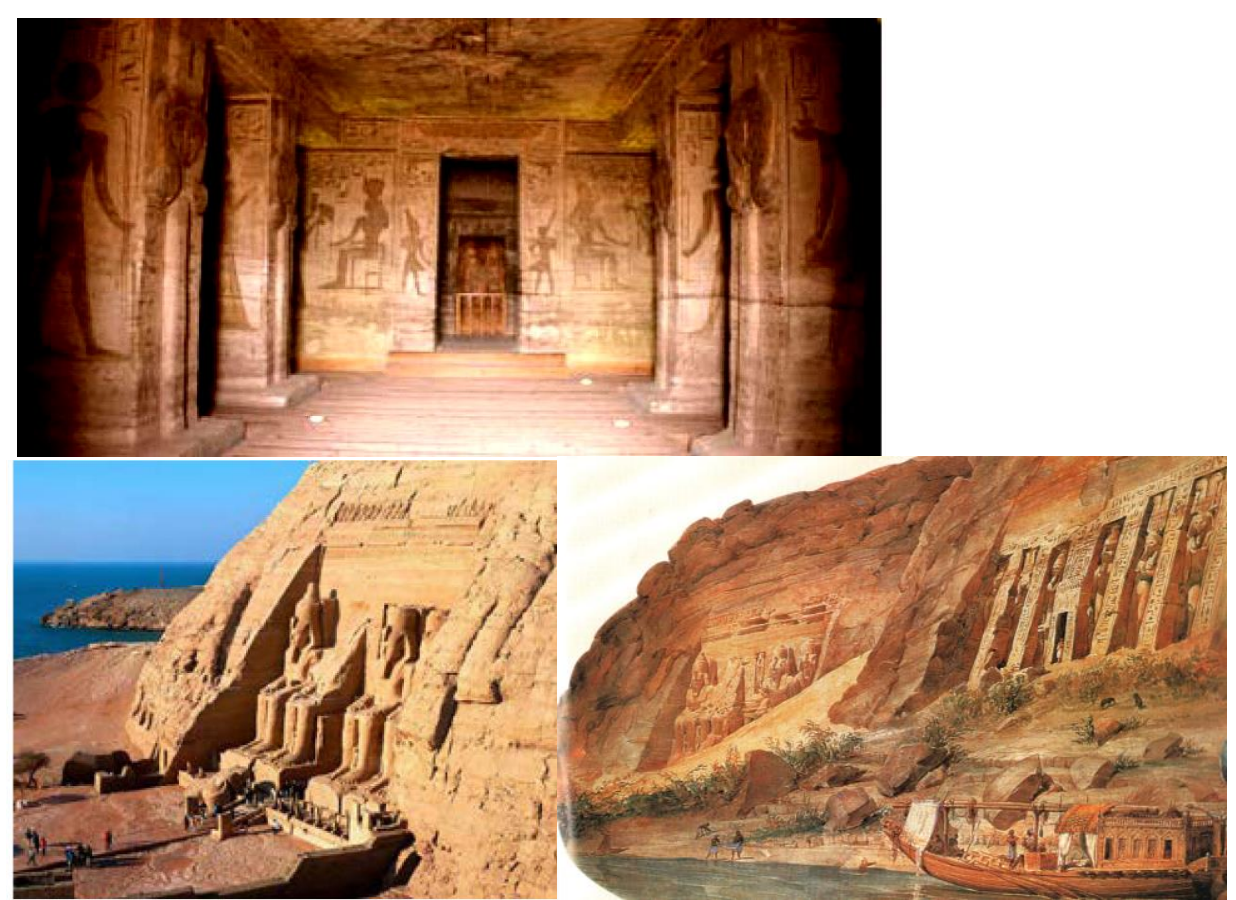

Figure 6. The Two Temples of Abu Simbel. The Wall Paintings of the Interior of the Great Temple, with Gigantic Figures, and the Current Environmental Insertion. The Picturesque Landscape of Rock-cut Temples Primordially Stems from $19^{\text {th }}$ Century Watercolor by Hector Hereau Source: Egitto, vol. 4 (Milan: Fabbri Editors, 1997-98). 
The funeral chapels of the Pharaohs, increasingly monumental and architecturally complex, show ever richer wall paintings, forming a real interior design, as in the Tomb of Ramesses I, in Ramesses II, Ramesses V and VI, and of all the Pharaohs of the dynasty.
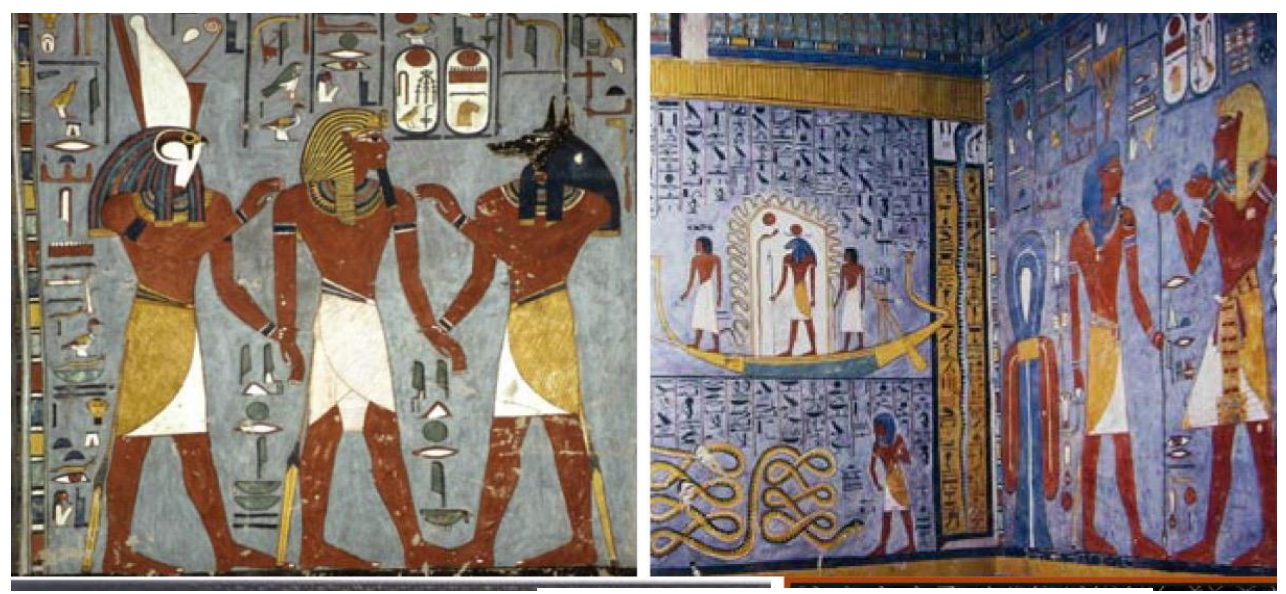

Figure 7. Tomb of Ramesses I. The Pharaoh with Horus and Anubis Source: https://tinyurl.com/yd2bfum2.

In particular, the tomb of Nefertari, one of the wives of Ramses II, contains one of the most beautiful and representative both painting cycles of the decorations and the highest technical level of the $13^{\text {th }}$ Century B.C.
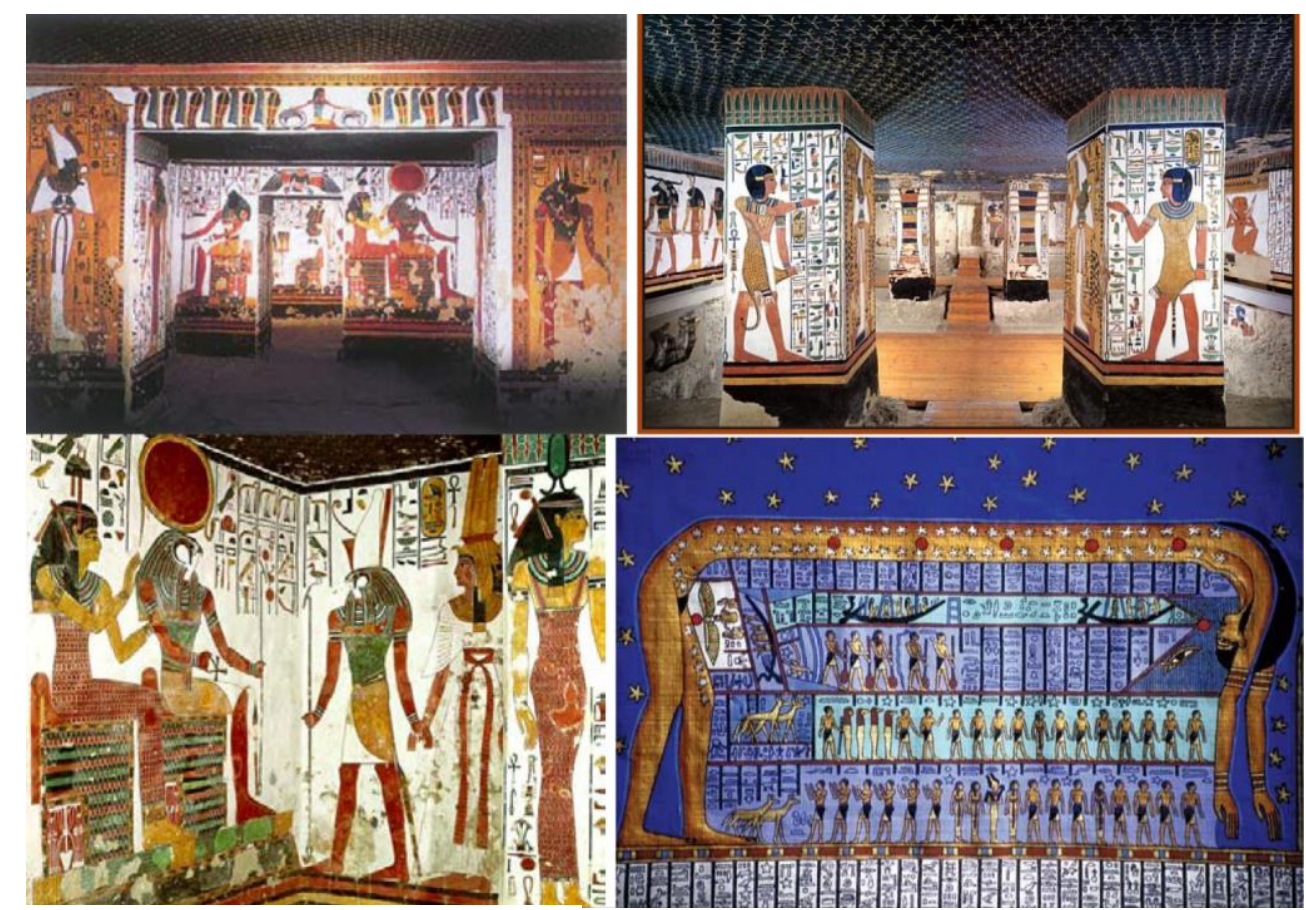

Figure 8. Nefertari's Tomb. Tebe

Source: https://tinyurl.com/yd2bfum2. 
The rich and complex decoration of the tomb of Ramesses V and VI. The back wall of the alcove is painted in light tones, in horizontal bands best with thick ceiling decorations and hieroglyphs, and thickly painted in horizontal bands, embrace the figure of the goddess Nut. Monumental figures mark the pillars and walls, creating also here a supernatural path.

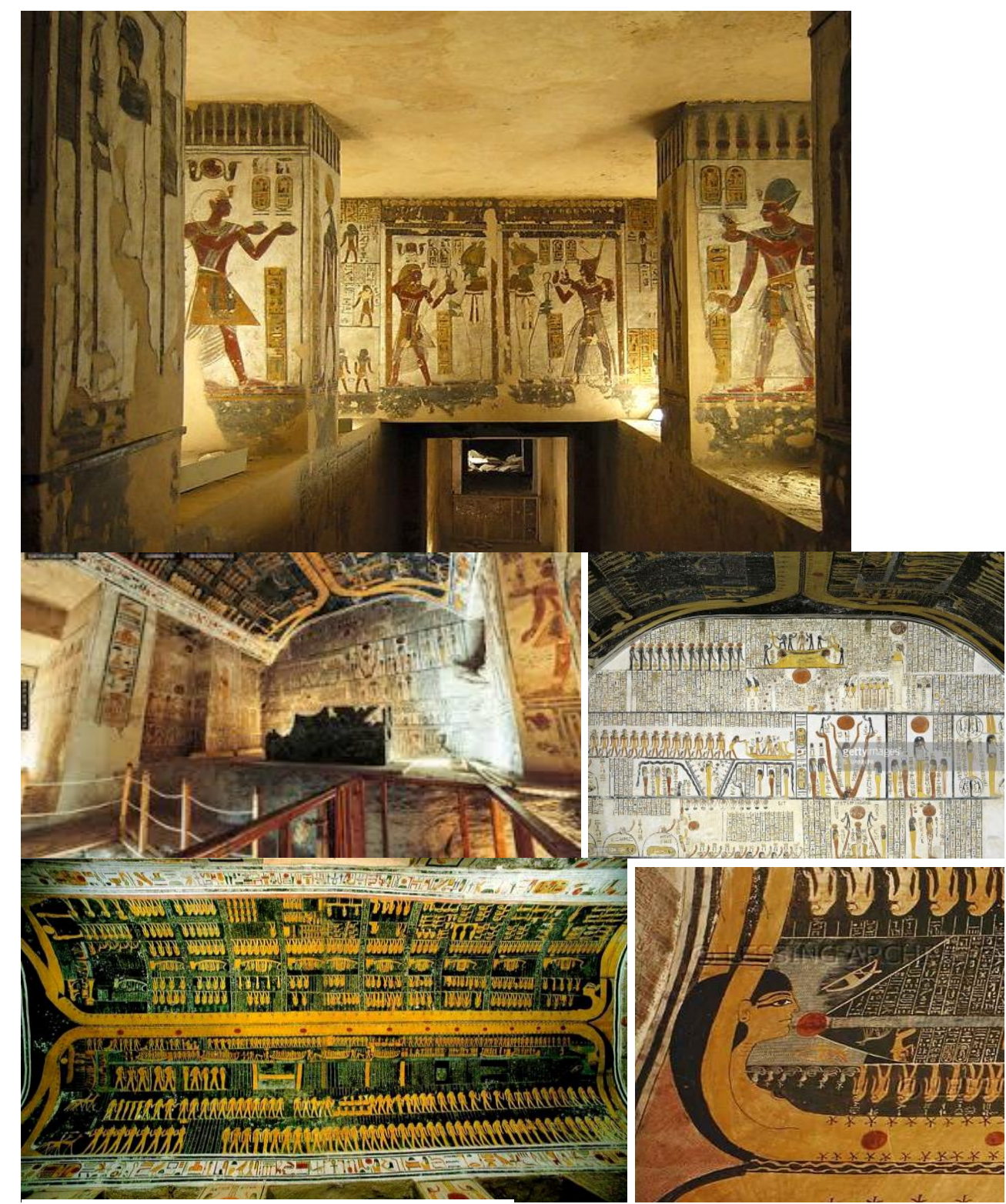

Figure 9. Tomb of Ramesses $V$ and VI

Source: https://tinyurl.com/yd2bfum2.

\section{The Temples}

Regarding to the temples, for both the exterior and the interior, the studies of archeologists and enthusiasts, and the many documentation arising from production of watercolors of David Roberts and other artists/archeologists in the 
19th is key to reconstruct the chromatic component applied to dense drawings carved on columns (stems and capitals), trabeation, walls, pillars, external fronts.

Exemplary the case of Karnak (Figure 10), documented now in colors only by watercolors of Roberts, from which flows all the importance of polychromy, who had both emphasize the stories represented in units of the stems of the columns and walls, of the stems of the columns and walls, both to create fantastic and unreal, between where power and religion.
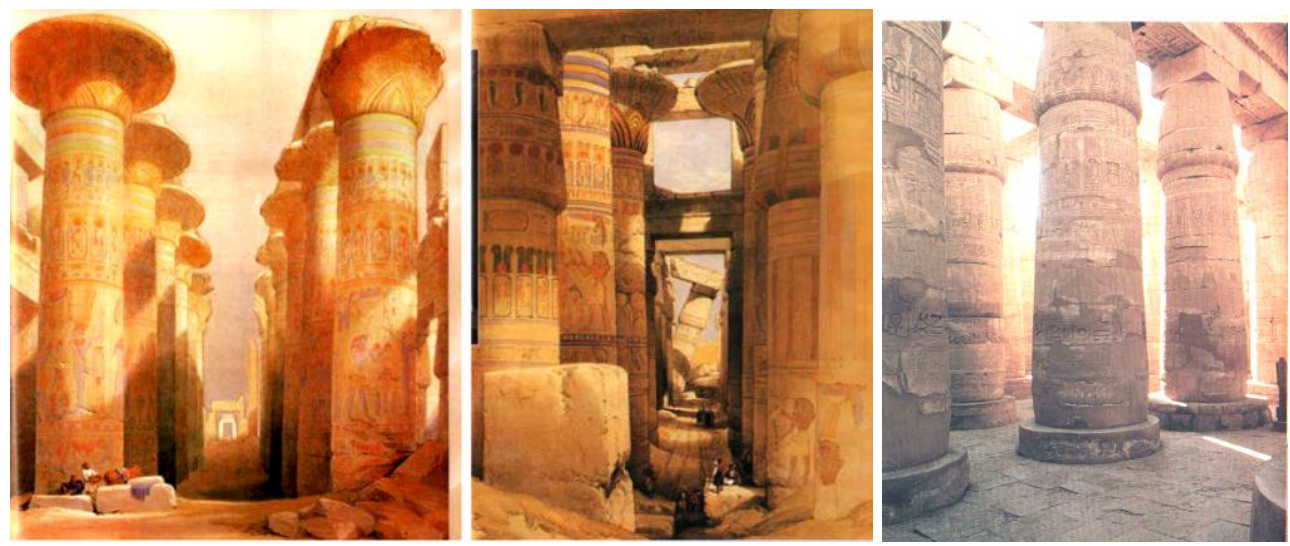

Figure 10. (Left) Karnak. Watercolours by David Roberts. The Great Hypostyle Hall of Karnak Temple, built by Seti I and Ramesses II and Next a Hypostyle Hall. (Right) The Current Status, with only the Engravings of the Drawing on the Columns, Now Devoid of the Rich Colors

Source: Egitto, vol. 4 (Milan: Fabbri Editors, 1997-98) (Left) Photograph by the Author.

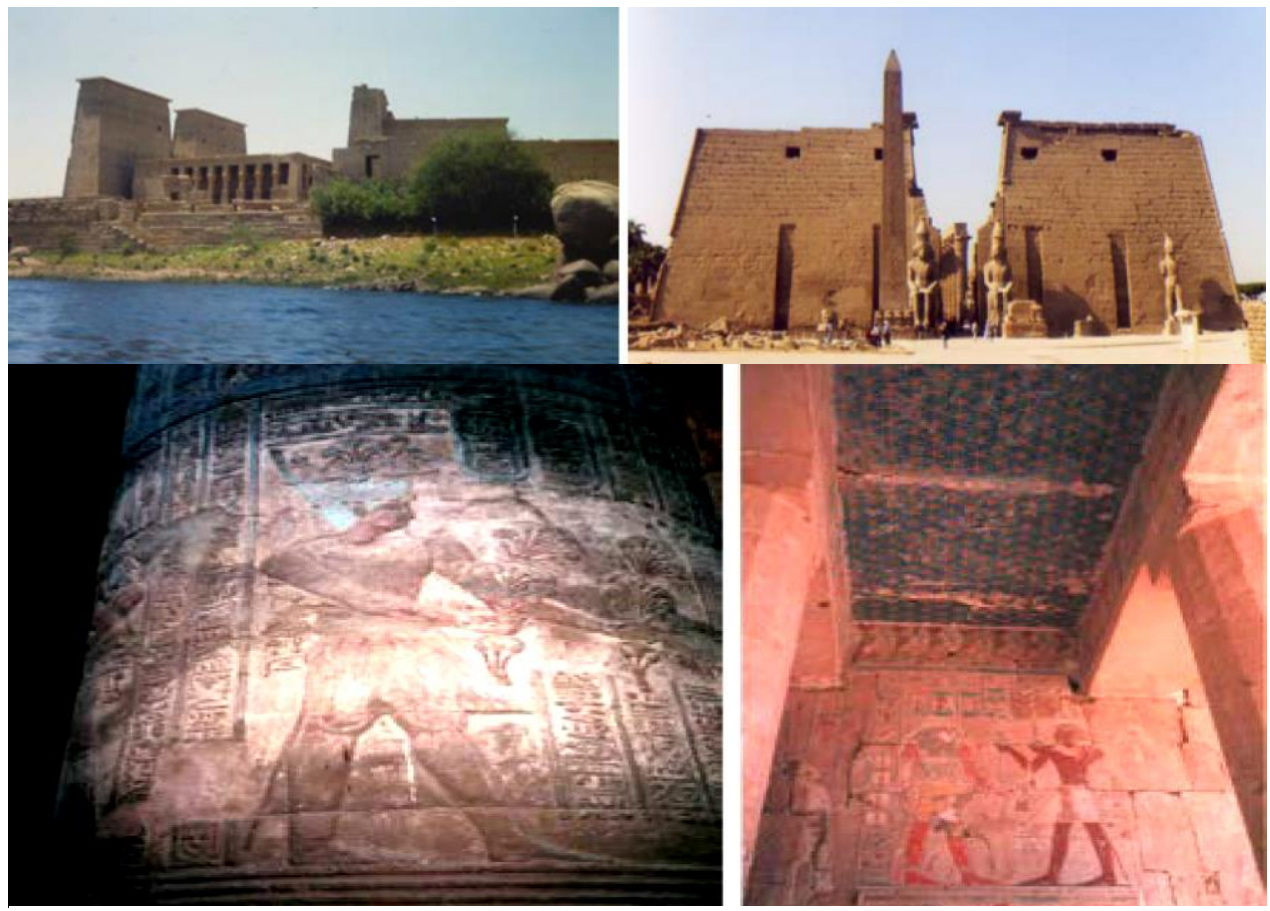

Figure 11. Luxor. Color Values in the Environment. Present, and Pictorial Tract of Interior Color Values at Present Source: Photographs by Author. 


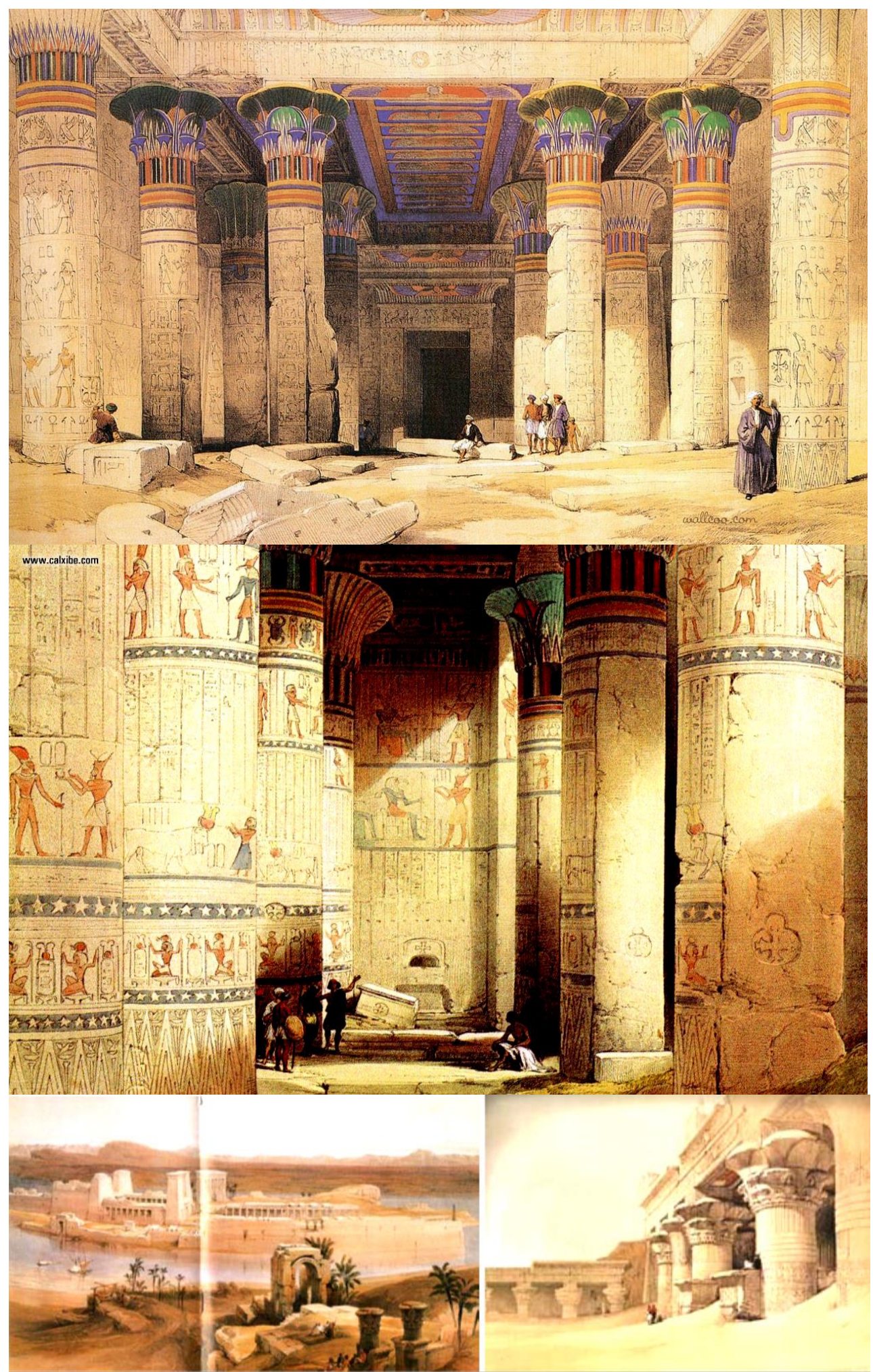

Figure 12. (Up) Philae. Watercolours by David Roberts. Hypostyle Hall of the Temple of Isis and Details of the Decorations (Below) Environmental Situation and Bank before Moving to the Construction of the Aswan Dam Source: Egitto, vol. 4 (Milan: Fabbri Editors, 1997-98). 

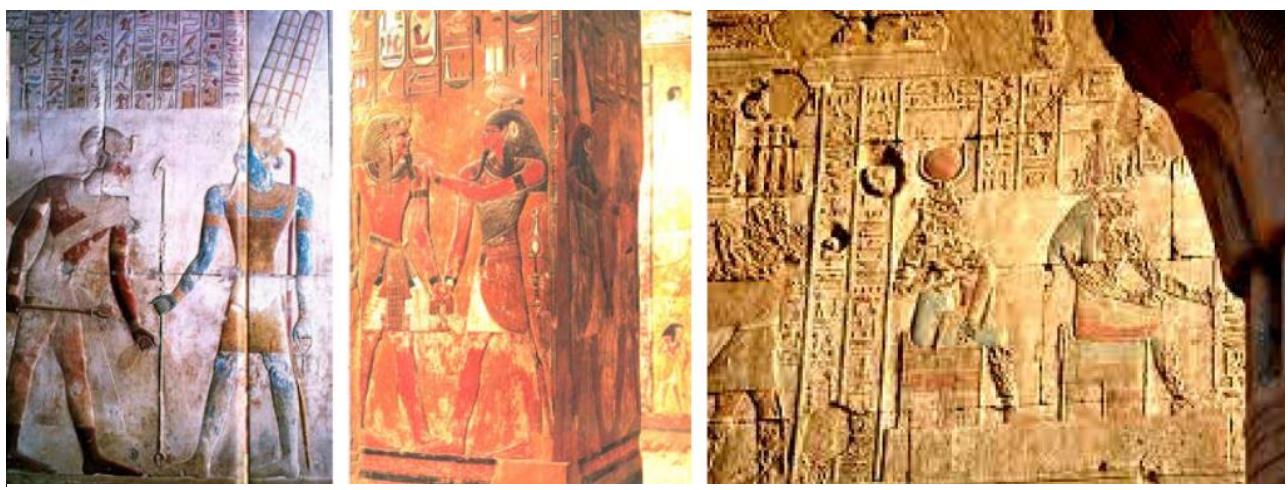

Figure 13. Details of Wall Reliefs, Painted or Sculpted, with a few but very Lively Colors. Temple of Abydos and Tomb of Sethi I

Source: Egitto, vol. 4 (Milan: Fabbri Editors, 1997-98).

\section{Color and Decorations in Mesopotomia: Use and Character}

More to the east, the art of the world of Mesopotamia does not have the same homogeneous characteristics as Egypt because the alternation of peoples of different race and culture, but from the founders, the Sumerians, continues a tradition that permeates the development of the next artistic cultures. The Sumerians (2800-2016), the Babylonians (2016-1595), the Assyrians (1245612), the Neobabilonians (604-562) and finally the Achaemenids (559-330) succeed each other.

In the Babylonian period, with the Semites (2016-1595), more than in Babylon, the main center, completely renovated at the time of Nebuchadnezzar, is the nearby city of Mari (brought to light in the excavations of 1933-1955), which in the imposing ruins shows the remains of the temples, and the great palace with valuable works, such as the bronze lions of the temple of Dagan and the stele of the famous Code of Laws of King Hammurabi. But, even more interesting, and rare, are the wall paintings, in the passages with sacrificial Scene, and an investiture, with few but decisive colors, that with expressiveness and elegance of the design confirm what is documented on the relationship between the Babylonian civilization and that, equally evolved, Cretan, in the same centuries.

In fact, thanks to the news written on the tablets found in the archives of the Mari palace, about the relations between the Babylonian and Cretan civilizations, the existence of commercial exchanges between Crete and Mesopotamia is certain, and it flows from the Syrian ports to export to Crete huge quantities of tin that the caravans coming from Mari brought to the coast after having crossed the desert.

Above all the posture and the representation of the figure and of the faces show a remarkable compliance: the bust is always three-quarters, the head in profile and the eye in front. All defined by a strong and dark line. But, in this regard, it's necessary to point out that the same mode of representation the figure is also widely found in Egyptian culture, with which it is documented that Crete, in the neo-palatial period (from the late $17^{\text {th }}$ Century B.C. until the first decades of XV century B.C.), a period of great political, artistic and 
economic splendor, in which it assumed the role of main cultural irradiation center of the Aegean and the Mediterranean. ${ }^{7}$ Crete entertained important commercial relationships, both with Egypt (where they could freely exercise their activity with the consent of the pharaoh), and with Syria (in whose coastal strip they had bases).

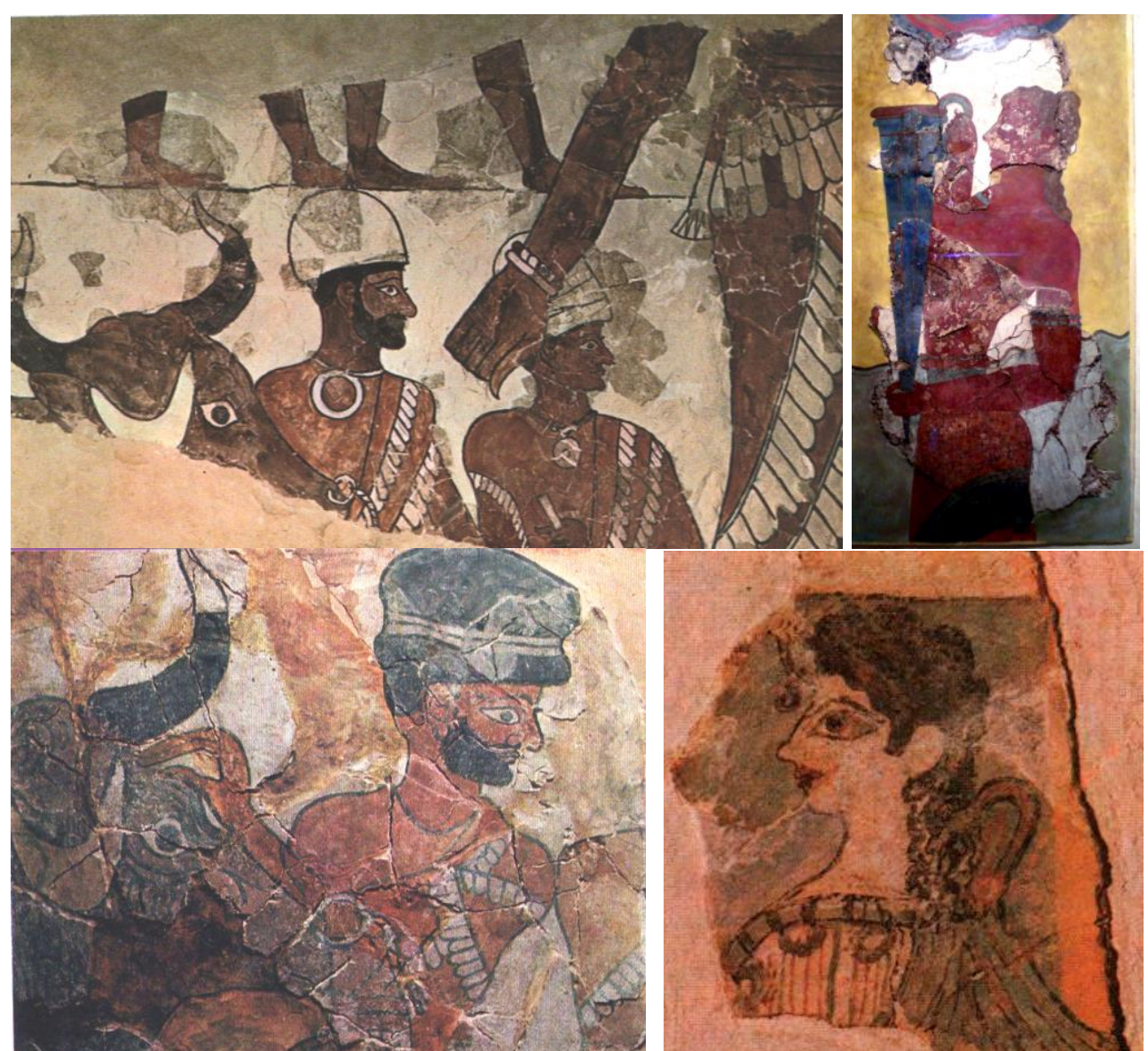

Figure 14. Sacrificial Scenes; Mural Paintings of the Palace of Mari. Aleppo, Archaeological Museum. On the right, above and below, Details of frescos in the palace of Knossos: Cupbearer, and "The Parisian"

Source: Negri Arnoldi, F., 1968. Storia dell'Arte. History de l'Art, Vol. I, Milano, Fabbri Editori. Photographs by author.

Between the $9^{\text {th }}$ and $6^{\text {th }}$ Centuries, the Babylonian art flourishes with Nebuchadnezzar II, (Neo-Babylonian period, 604-562 B.C.). The city of Babylon builds grand palaces with gardens, temples, towers-ziggurat; at the urban level, strong walls, documenting with few parts retained as Ishtar Gate (575 A.C.), the strong and vibrant color component resulting from coatings in light blue, blue and turquoise glazed tiles, on which stand out in horizontal bands lions, dragons and bulls in golden yellow, with, also, great chromatic effect that mark the great belt even from afar.

7. Ciotta, Architetture Egee. Momenti di Culture Variegate e Premesse alla Civiltà Greca, 2013, 10-14. 

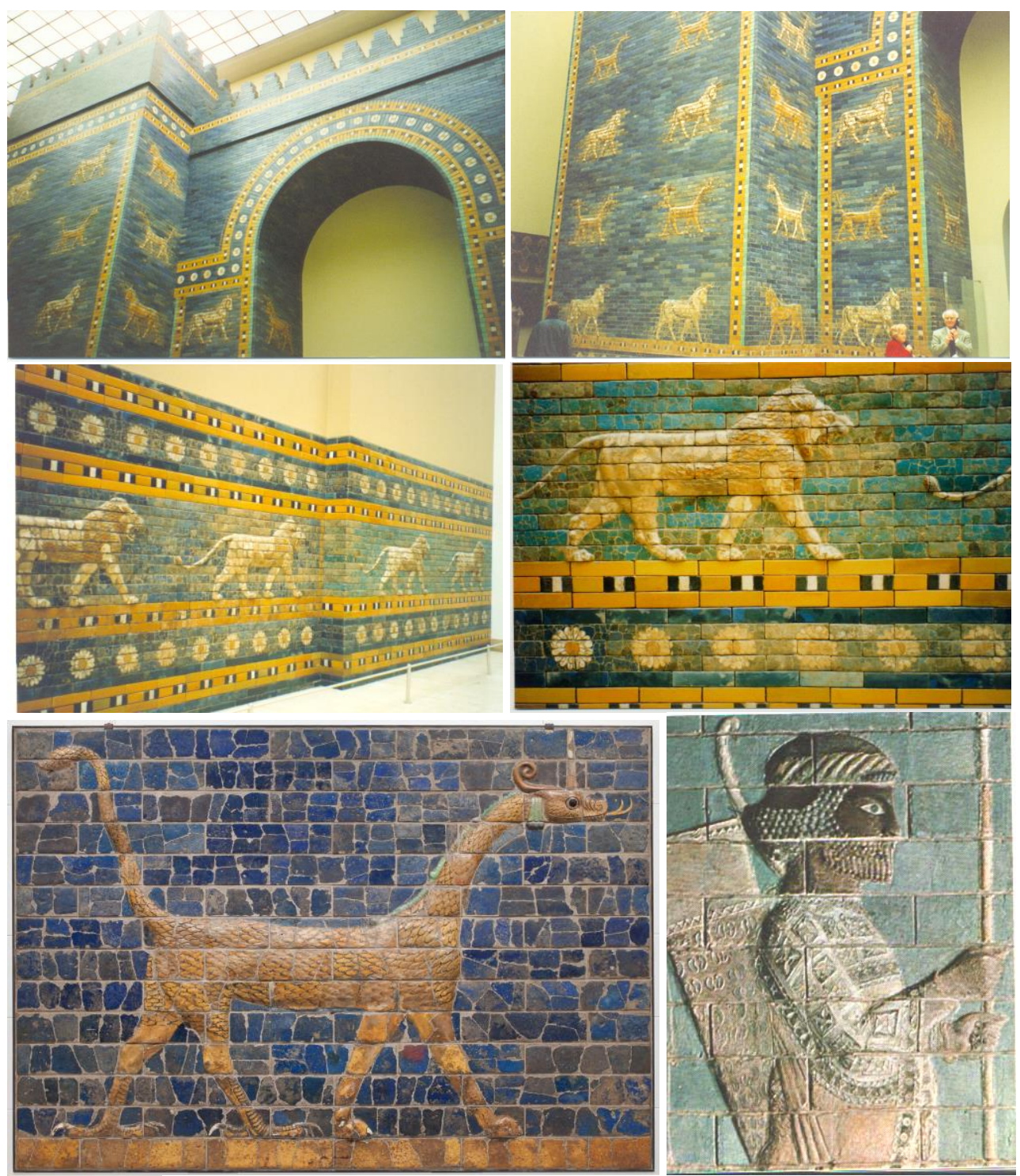

Figure 15. Babylon. The Ishtar Gate. Polychrome Ceramic Tiles, Wall Tiles to Decorative Patterns (Bottom Right) Susa, Frieze of Archers and Lions (Persian Empire)

Source: Negri Arnoldi, History de l'Art, 1968. Museum in Berlin: Photographs by Author.

In 539, with the conquest of Cyrus, Babylon became part of the Persian Empire. With the reign of Cyrus II, the founder of the Achemenide dynasty, the great expansion began and it continues with the kings Darius, Xerxes I, Artaxerxes I and II, who carries the Iranian armies to Egypt and to the gates of Greece. If in large capitals shutters, Pasargadae, Persepolis, Susa, the grand palaces are richly ornamented with stone carvings that celebrate the grandeur of the Achaemenid dynasty, in some cases we find here also the adoption of Kassite relief and enameled bricks technique, like those that make up the beautiful and evocative Frieze of archers and lions, in Susa. The discovery, in Persepoli and Susa, of Greek ceramics and sculptures, which reveal the commercial and artistic relations between the two countries, is very important 
to highlight the relationship between the different artistic cultures, documented by the presence of Greek sculptors in the great building sites of the Persians palaces, mixed with various influences of local artistic cultures.

So in the East the importance of color is expressed especially in ceramic materials in bright colors (light blue, blue and green, yellow), either in monochrome, or in decorative patterns; colors that identify frequently domes and walls of mosques, tombs, or madrasas, as shown by some of the many examples of decorated surfaces with minute drawings ceramic materials of the Oriental world. This is transmitted and spreads in the Islands (Sicily, Sardinia,), and in coastal areas of southern Italy traveled by direct Mediterranean routes to the Iberian Peninsula. In Sicily, where there are numerous polychrome domes with decorative drawings, often geometric, such as in Palermo, or in Naples, Amalfi and Positano, and also in the use of colored ceramics, as in the garden of the Convent of Saint Chiara.

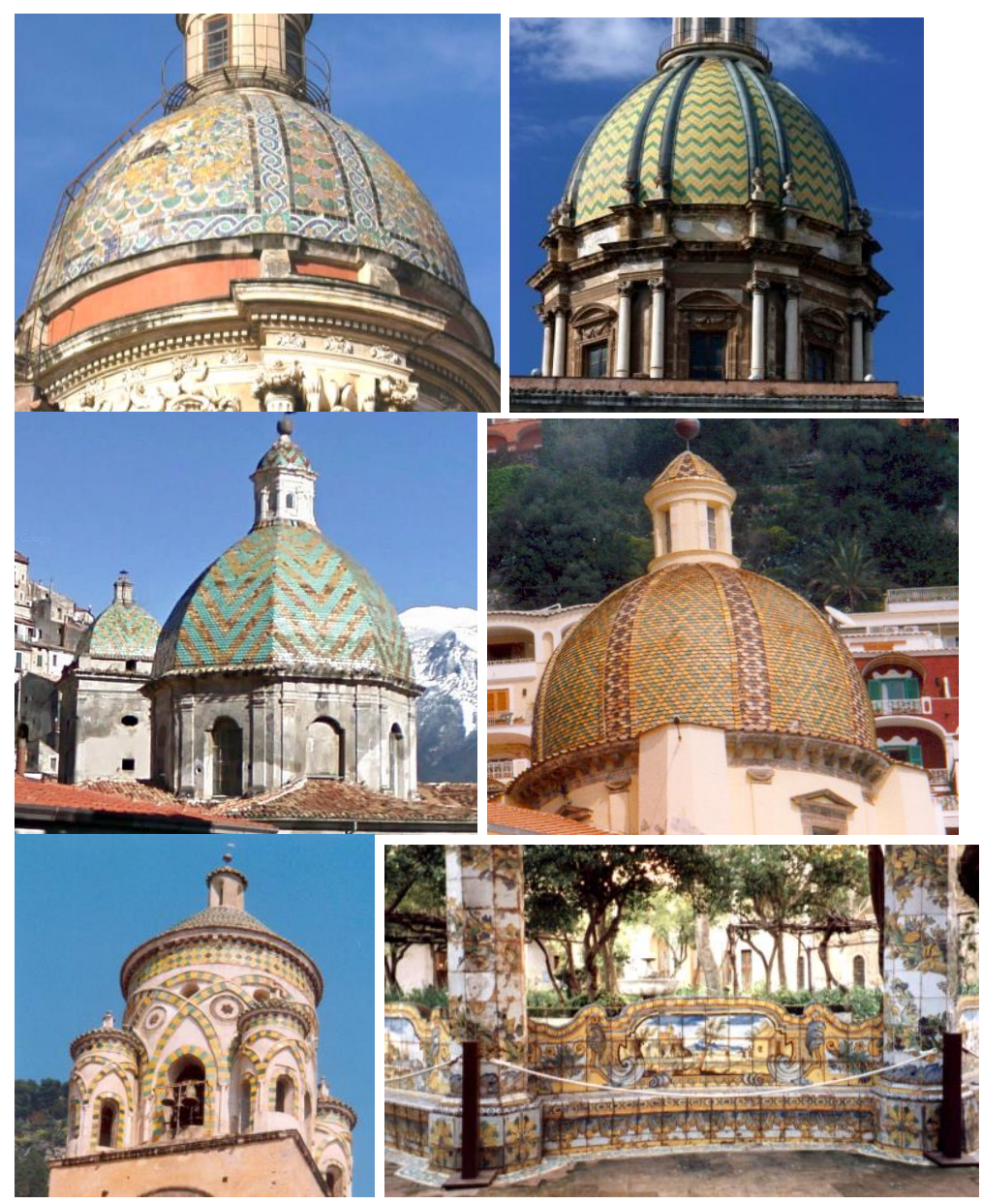

Figure 16. (Top) Palermo. Sicily. Dome of the Church of Major Carmine and Dome of the Church of the Teatines (Below) Dome of the Collegiate Church of Morano. Calabria. Ceramic Domes in Positano, Amalfi, and Polychrome Majolica in the Garden of the Convent of Saint Chiara in Naples, which Show the Acquisition of this Decorative Practice 

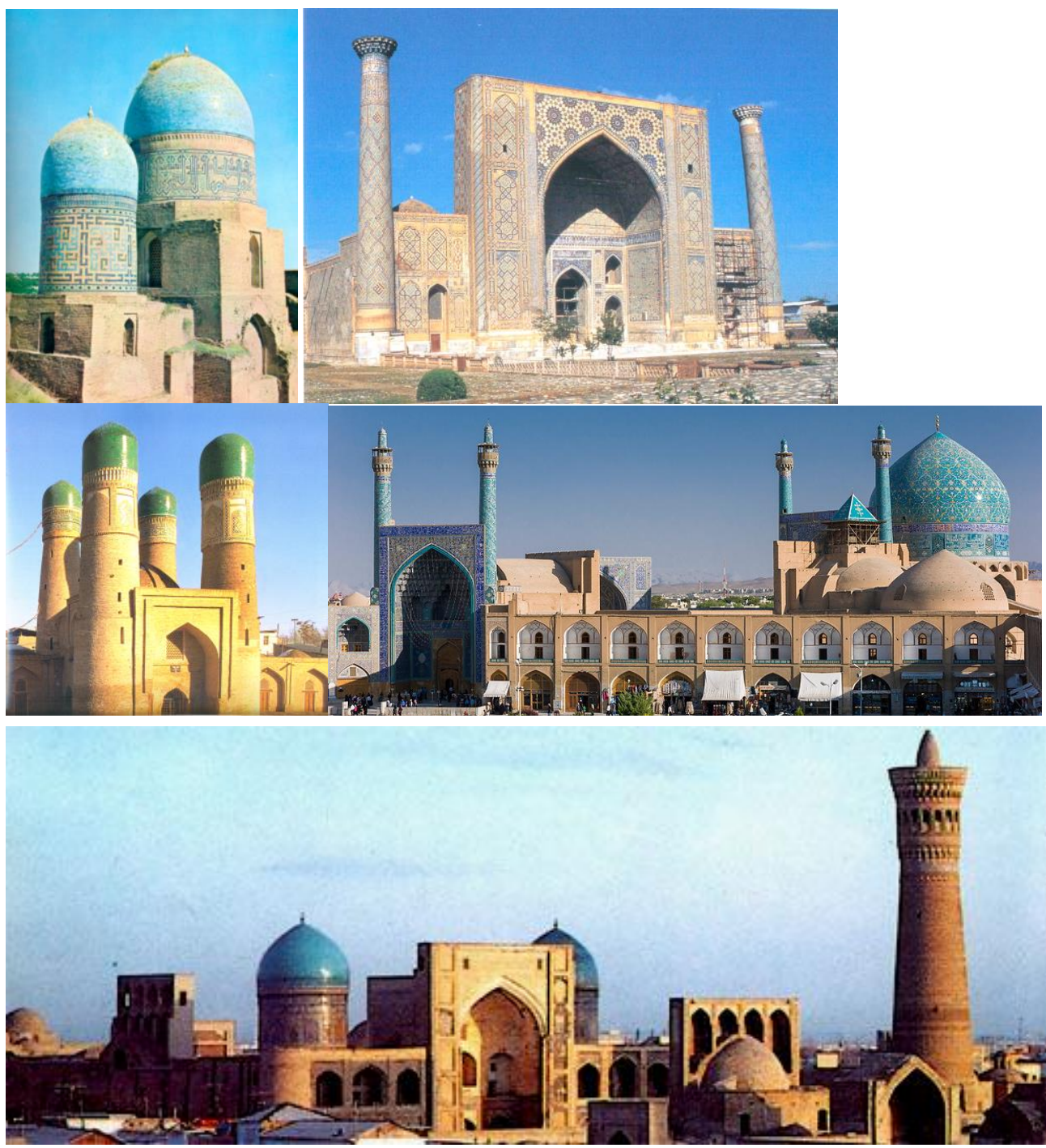

Figure 17. Samarkand (Top) Complex of the Mausoleum Gur-i Mir. (Middle) Domed Tombs (Right) Ulugh Beg Madrasa (Below) Bukhara. Chor Minar. The Four Minarets of the Madrasa. The Shah Mosque, Isfahan. Bukhara. The Landscape. Here is Counterpointed by Domes and Minarets that Identify the Territory and Culture

Source: M. Hattstein and P. Delius, Islam. Arte e Architettura (Ulmann Editore, 2004); The $19^{\text {th }}$ Century Iconographic Documentation. 


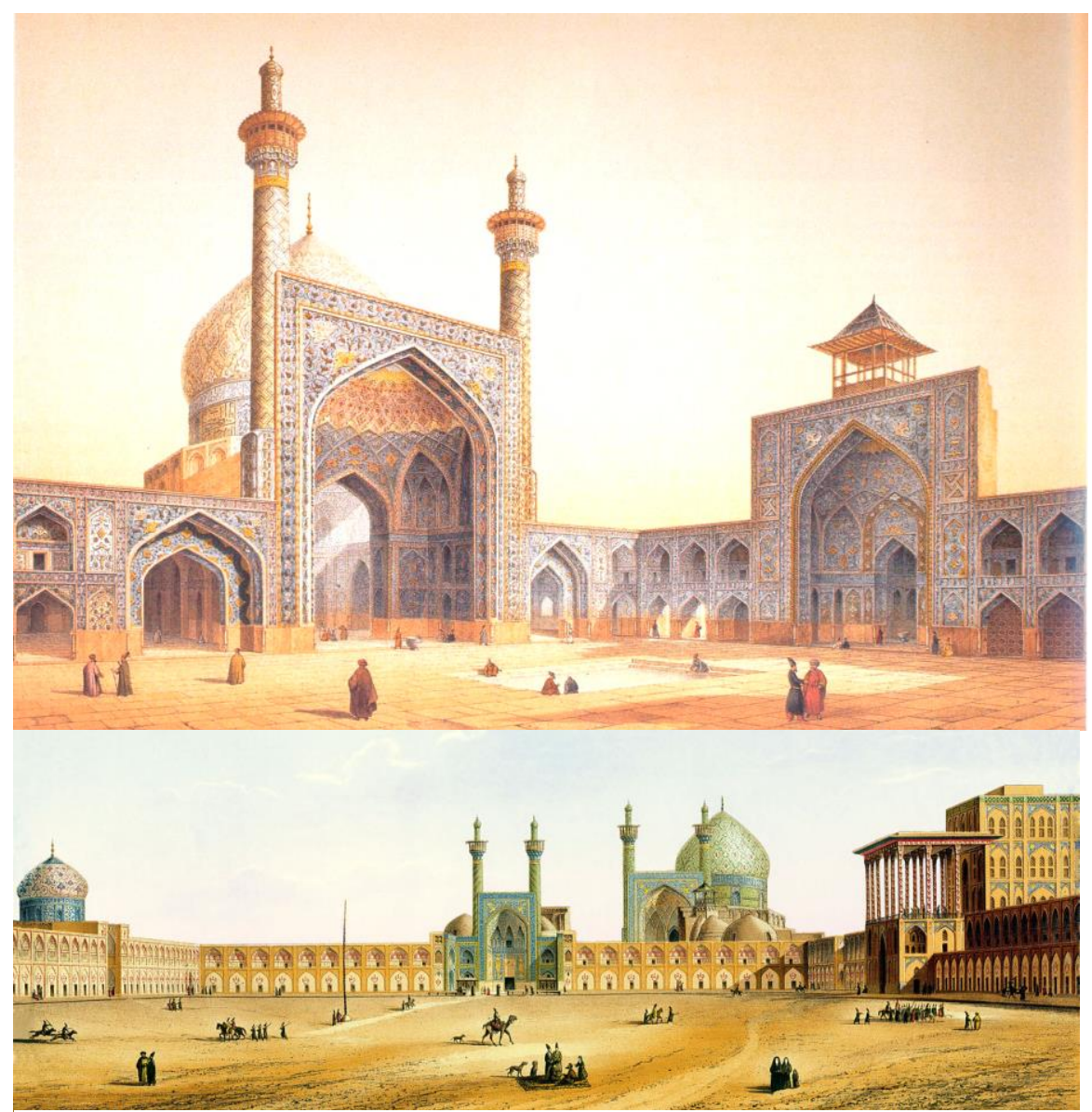

Figure 18. Pascal Coste (1787-1879). Representation of the Square of Naqsh-e Jahan, Isfahan. The Shah Mosque. The French Architect Visit Persia in 1841 (Below) The Landscape of Huge Square

Source: P. Coste, Monuments Modernes de la Perse (Paris: A. Morel, 1867).

\section{Color and Decorative Features in the Phoenician Culture: Use and Characters}

The Phoenician civilization is of fundamental importance in the history of ancient art, and for the topic at hand, for function that plays (ca. 2750 B.C.-550 B.C); in fact, this people of tradesmen and experienced navigators spreads Egyptian and Asian art throughout the Mediterranean basin, as from their coastal centers as Ugarit, and from the two large trading emporiums of Tiro and Sidone it exerts a strong and wide action for exchange and linkage between the various cultures of the people of Asian and African hinterland. Their artistic production was very greatly influenced by art of the countries with which they traded. In particular, the Phoenician influence, as well as Cretan one, in the formation of Greek civilization is also evidenced by the adoption by the Greeks of the Phoenician alphabet since the $9^{\text {th }}$ Century B.C.

In fact, Egyptian, Assyrian, Hittite and Cretan influences are frequent in their works: mainly they are manufactured articles, mainly sculptures and reliefs, but also gold jewelry and metallic artifacts, of which there are notable examples. Important are the numerous gold death masks, used in the Mycenaean civilization, 
which refer to the civilization of the Aegean world. A vast trade of bronze and gold existed (which are supposed to exist in real industries) with the exporting of products to all countries of the Mediterranean and the Middle East.

A network of techniques, styles, decorative features, materials, which is transmitted for knowledge and for actual spreading of the artifacts but sicuramente also for the mobility of artists and craftsmen in a sea so frequented by all these people. Instead there are not traces and findings of painted apparatus and colors, except for some small sculptures with traces of polychrome. Their art, even if not characterized by elements of particular originality, has, however, for the diffusion in this epoch, notable influence on the minor production of many close (Syria, Palestine) and very distant countries. ${ }^{8}$

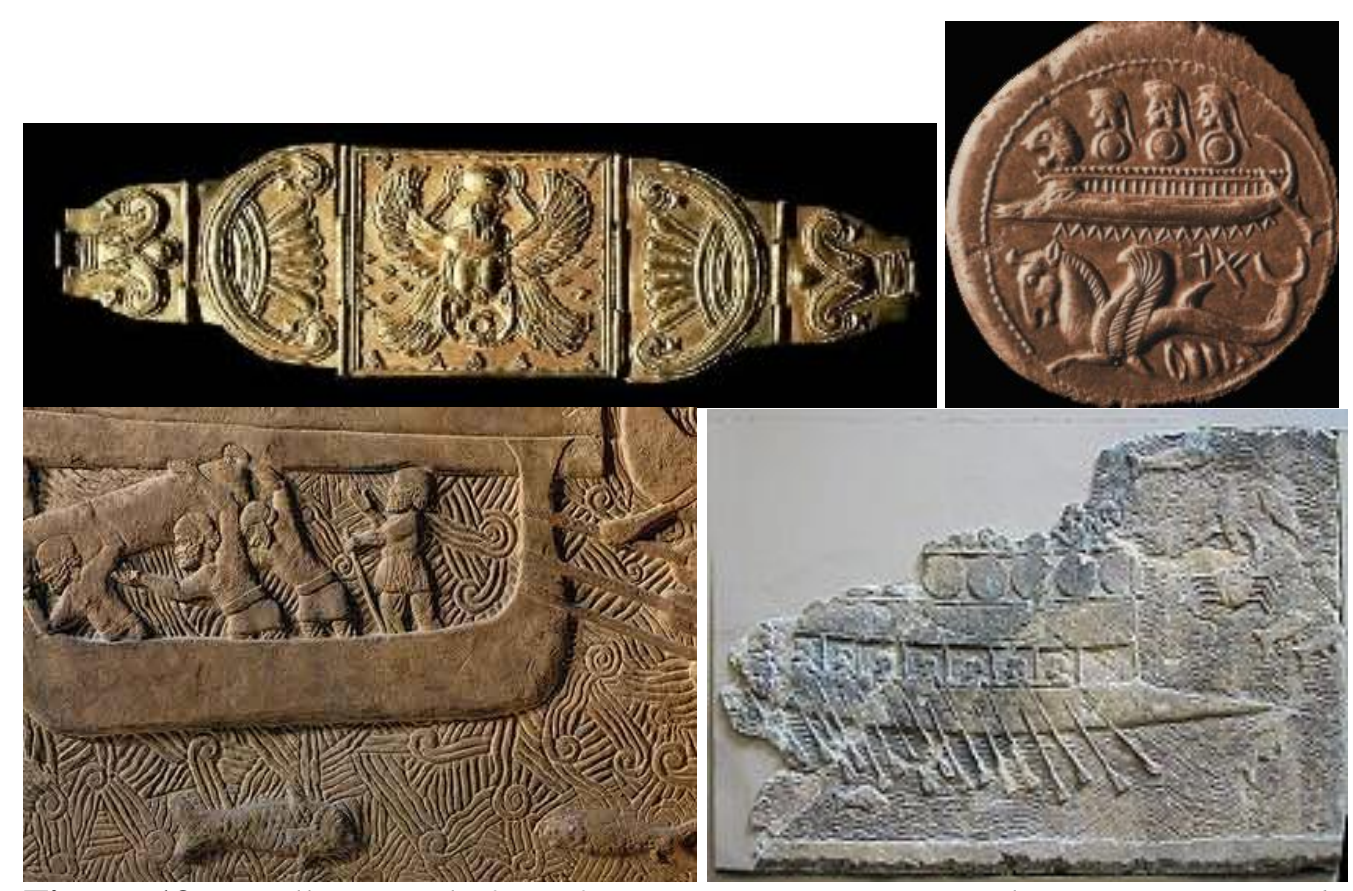

Figure 19. Small Bas-Relief Artifacts, in Precious Materials or in Stone on the Theme of Navigation; Last one, the Bas-relief with an Assyrian Ship, of Phoenician Production

Colors and Decorative in Cretan Civilization-Mycenaean: Use and Characters

The Aegean civilization flourishes in the early $3^{\text {rd }}$ Millennium B.C. in the Eastern Mediterranean area, and in particular on the island of Crete, in the Greek mainland and the Cyclades Islands, following the invasion of the city of Troy, (on the coast of Minor Aia - today's Turkey), politico-economic and cultural centre of gravity between East and West, with trades and exchanges with the internal regions of Anatolya. The effects of this migratory event occur mainly in the introduction of both the megaron as unit in the central-northern part of Greece (Boeotia and Thessaly), and the use of metals (gold, silver, copper), giving rise

8. Negri Arnoldi, Storia dell'Arte, 1968, 50-51. 
to the formation of metal civilization; in the first half of the $3^{\text {rd }}$ millennium even by the interweaving of business relationships with Middle Eastern populations, which broadens artistic repertoire. ${ }^{9}$

The invention of bronze (2400 B.C.), and the subsequent occupation of Indo-European peoples of Anatolia and Greece (2200-2100 B.C.) marked the takeoff of the Cretan civilization oligarchic and allow the King of the main cities of the island to promote an intense building activity (first palaces of Mallia, of Knossos and Phaestos) and acquire a significant power in the Aegean (2100-1700 period). Historical events immediately following the earthquake occurred probably in 1700 B.C., after about four centuries of invasion of Troy, the recovery and development of material culture and Mycenaean and Cycladic style, as is attested by the splendid palaces of Mycenae, Tiryns and Orchomenus, and the magnificent display of the frescoes in the residences of Thera (modern Santorini) that are the most elegant frescoes of the Aegean world.

These frescoes are characterised by sinuous lines, continuous but resolved that make alive, as at the time of the representation, figures, animals, plants, from strong decorative taste and color. Interesting then are the wide representations of landscapes and seaside city, which develops high sequential narratives compositional and decorative taste, accompanied by a playful symbolism. This valuable heritage of frescos emerged mainly from the excavations of Akrotiri, 1968, reporting a few examples relating to the Western House and the House of the Ladies (Figure 20).

The importance assumed by the Mycenaean and Cycladic centres, shortly after 1700 B.C., fails, however, to stop the growth of Cretan hegemony in the Mediterranean port: the latter, becomes permanently, since the mid of the $17^{\text {th }}$ century. B.C. until the first decades of the $15^{\text {th }}$ Century unchallenged power in the Mediterranean, as B.C. testified from the presence of luxurious palaces rebuilt in neopalatial period or second palazzos, with joints and icnografici schemas that correspond to the needs of comfort and refined decoration fresco wall or plaster that adorn the rooms and large halls (Megara). At this stage the Cretan merchants taking and intensify their trade relations both with Egypt, both with Syria, and construction activity resumes characterized by a grandiose monumentality, perhaps due to oriental touches, therefore the reconstructed buildings and the many 'villas' built in the territories of their administrative relevance are distinguished by the refinement of composition. ${ }^{10}$

9. Ciotta, Architetture Egee. Momenti di Culture Variegate e Premesse alla Civiltà Greca, 2013.

10. Ciotta, Architetture Egee. Momenti di Culture Variegate e Premesse alla Civiltà Greca, 2013. 
Vol. 5, No. 3
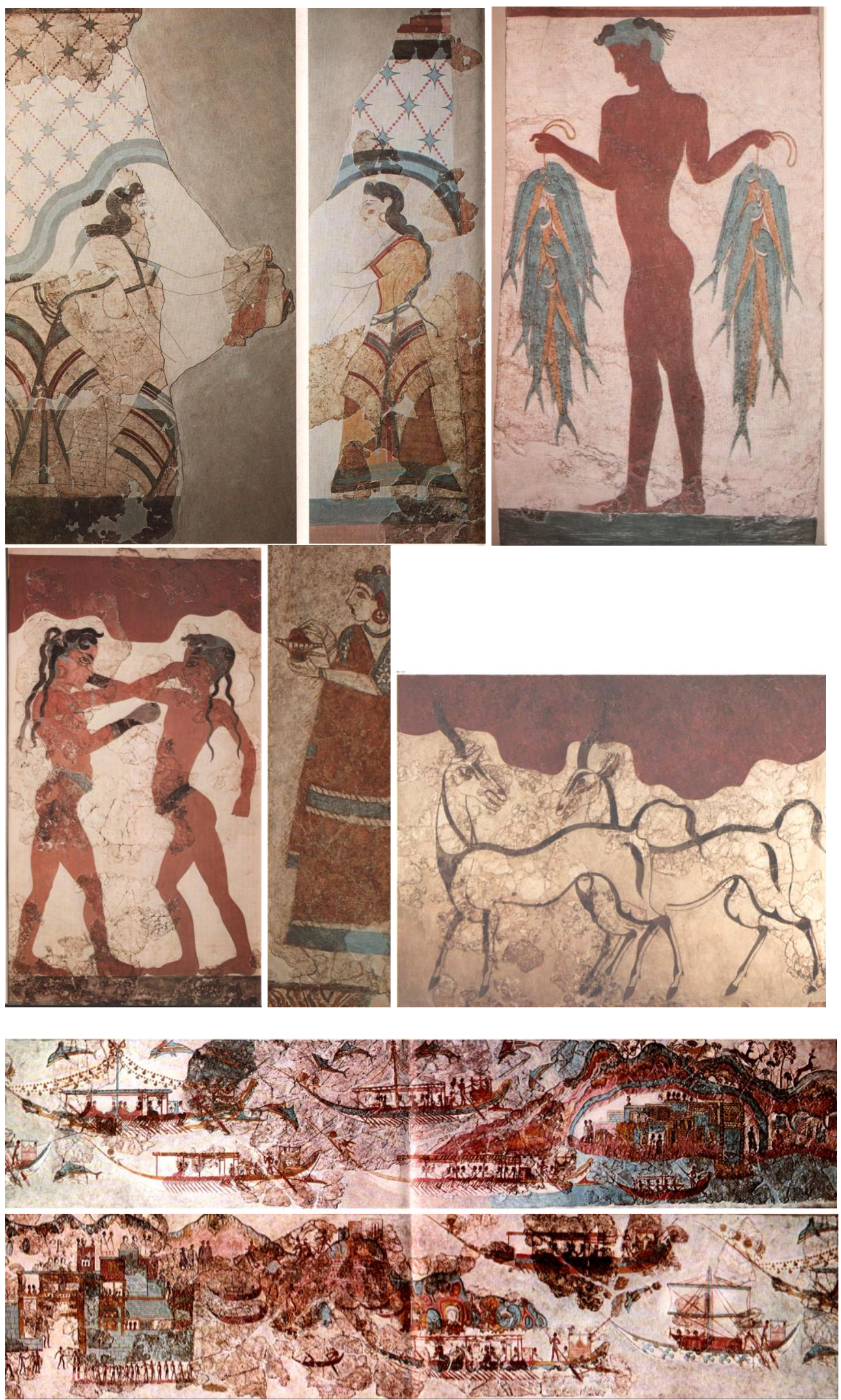


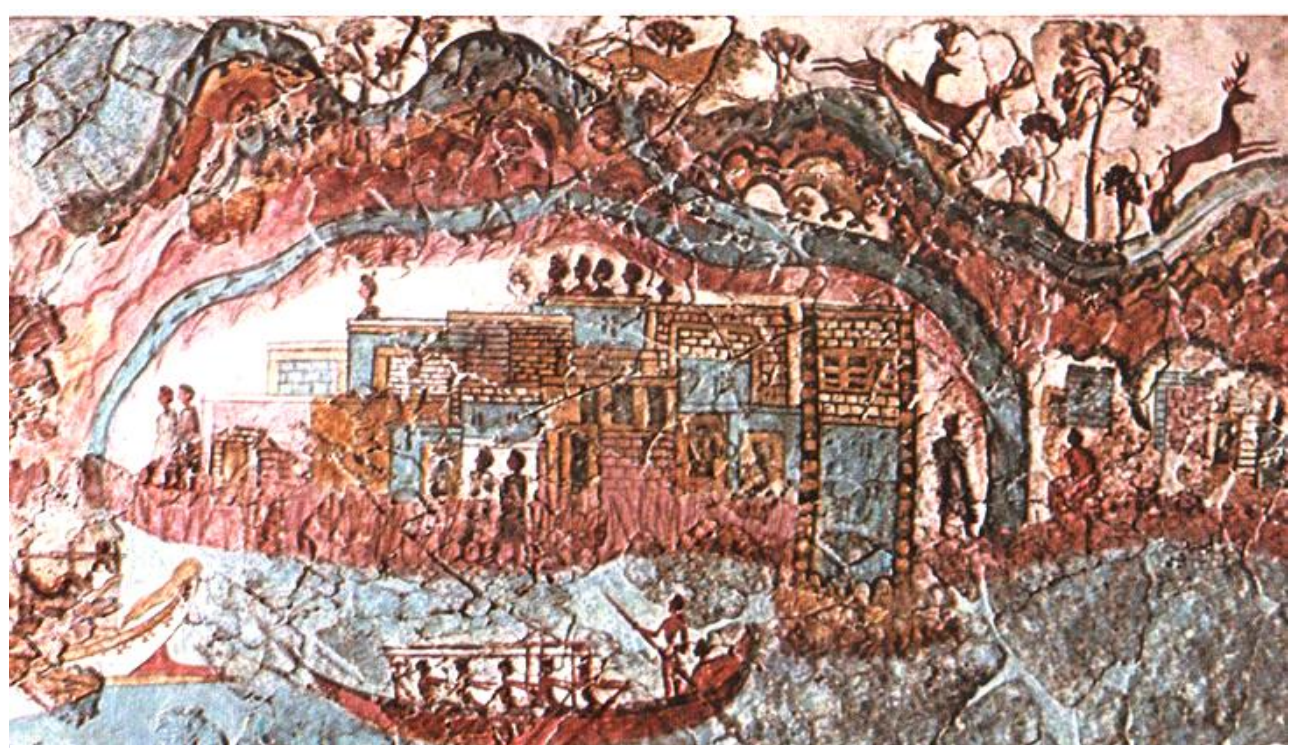

Figure 20. (Starting from top left) The House of the Ladies, Ladies Room, Two Female Figures (next) Naked Young Fisherman, by Combing Libyan Source (under) Young Boxers, with the Same Hairstyle. Next, a Young Priestess, African Features, and Two Gazelles, the Typology that Frequently Appears throughout the Egyptian Art. Underneath is the Long Frieze Known as the Libyan or Miniature Naval Expedition, which is precisely to Imagine a Story that Unfolds between the Sea, the Coasts and the Seaside city. This Fresco Fragments Saved from Three Walls was appointed by Subject (below, first) the Second City and Warships, Including the Flagship (second) The Rest of the Fleet and the Third Largest City. Under still a detail, most Valuable, the Representation of the City and the Natural Environment, both in Map and in Vertical Projection with its Elements, Architectural Forms and Construction Materials, including the Animals, that Inhabit the Land and the Sea Source: Papaioannou and Skouroyannis, Santorini, 1977.

With the political rise of Knossos, Minoan culture expands into mainland Greece, the Cyclades, the Dodecanese, the Anatolian coasts, and even into Egypt and Galilee. In fact, refined Minoan objects are found in tombs in Mycenae, in the necropolis of Argolis and Messenia, attesting the Minoan presence in the Peloponnese. Stone vessels of Egyptian origin circulated in Knossos, while the scenes of the Keftùs in the tombs of the early XVIII Dynasty and the Minoanizing paintings that decorated the palace of Tell elDab'a-Avaris confirm the close relations between the Minoan and Egyptian worlds. The pictorial fragments and a frescoed floor of the Palace of Tell Gabri in the Western Galilee are other evidence of direct relations between the Cretans and the Hyksos. ${ }^{11}$

11. Ibid, 74 . 


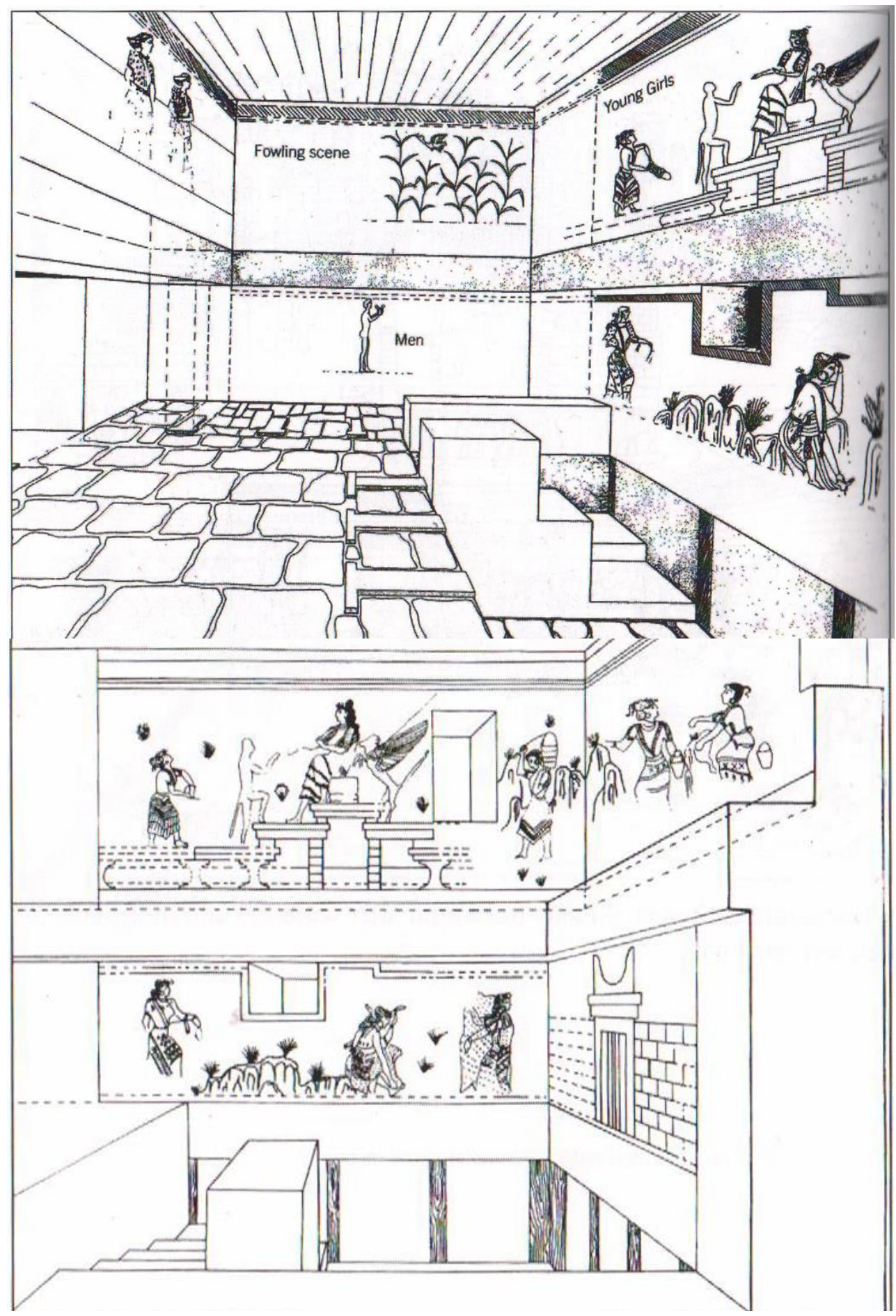

Figure 21. In these Two Reconstructions, the Composition, the Figures, and the Narration Clearly Show the Sacredness of the Egyptian and Eastern World in General

Source: Ciotta, Architetture Egee. Momenti di Culture Variegate e Premesse alla Civiltà Greca, 2013. 


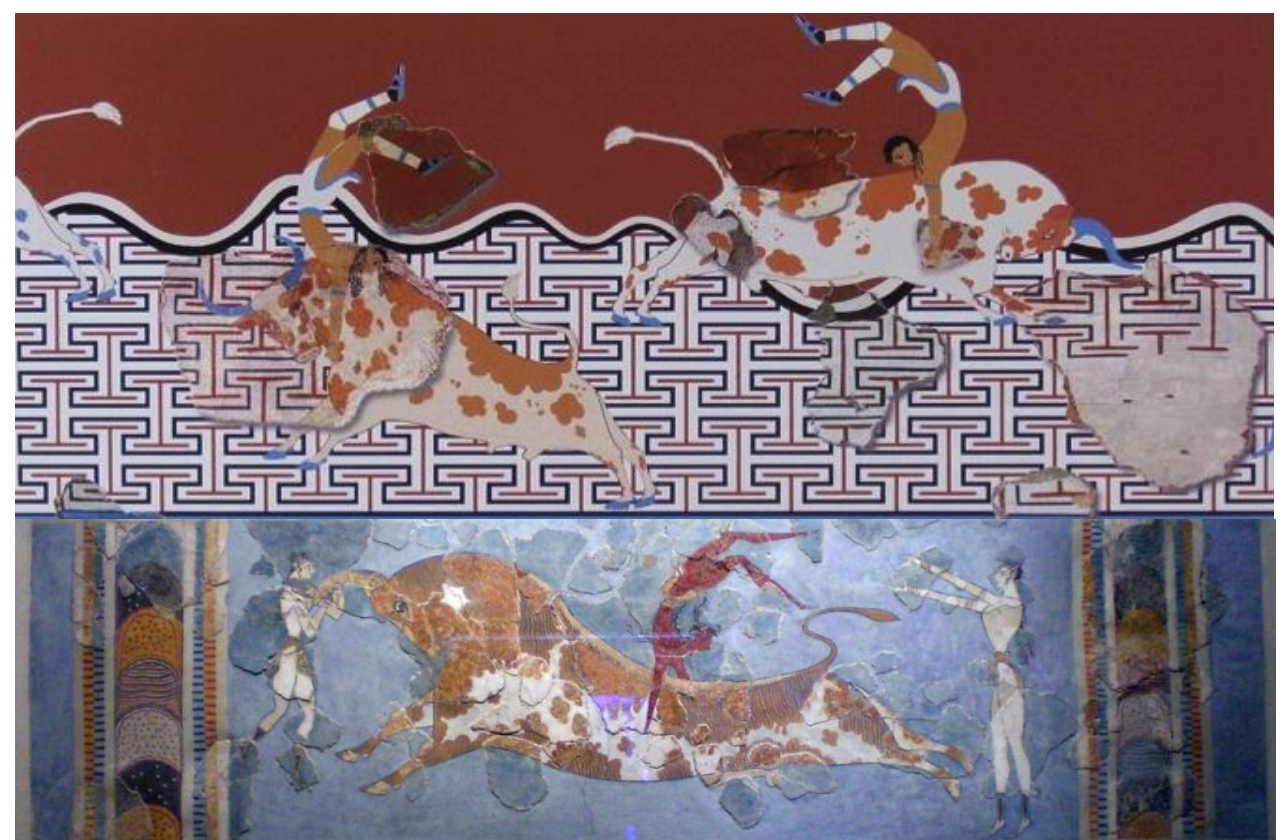

Figure 22. (Top) Palace of Tell el-Dab'a-Avaris, Capital of the $15^{\text {th }}$ Hyksos Sovereigns Dynasty. Games with the Bulls (Below) Palace of Knossos, Fresco with Scene of Tauromachia

Mycenaean occupation of Cretan's Cycladic territories, that took place around 1425 B.C., created rapid changes in political Mediterranean geopolitics, because now is the city of Mycenae holding the political supremacy in the Mediterranean, keeping it unchallenged over the next two centuries. The arrival (1200 B.C.) of different ethnicities, coming perhaps from the East, put an end to the political power of the Mycenaean civilization, but the gradual stabilization of the new invaders does not have the force to cancel the established tradition of the Aegean civilization renumbered by now constant reference in the process of formation of Greek civilization, giving a strong contribution to the development of an absolutely original art.

In the context of the Cycladic culture, the Cretan art show characters absolutely new and original. Symbolic and religious content abandoned tighter, using color and decorative features, extended everywhere in both the exterior and the Interior of the Royal palaces in their various phases of construction, as evidenced by those still preserved. Here the themes related to nature and festive life wildlife (flora and fauna) are shown with a short but lively colors, in immediate contact with those of nature.

The first Royal palaces of Knossos and Festos are erected at the beginning of the $2^{\text {nd }}$ Millennium B.C. on the island of Crete; they went then in ruins around the $17^{\text {th }}$ Century B.C., during the period of the first palaces or Minoan medium (ca. 2000-1700 B.C.) they are reconstructed as great royal palaces and, after being completely destroyed around 1700 A.C., they are rebuilt again.

From the point of view of landscape it is essential the placement in the environment, on a hill, served by steep stairs and narrow passages; corridors 
and paved courtyards served numerous environments, distributed according to function, with a rich internal decoration, marble floors and painted walls.

But it is in the period of reconstruction of the Minoan palaces, the recent seconds (1700-1650 B.C.), original development of this civilization with great centers at Knossos, Phaistos, Hagia Triada, Mallia. The new palaces, that reuse for much of the facilities of the first palaces, have a plant even more complex, and are much larger than before; real architectural complexes, which stand in a relationship of continuity between architecture and territory, between man and nature. Planimetric systems of the neighborhoods surrounding the central courtyard have a greater compactness of the parties. Central courts, the hubs of the building continue to be held for bullfighting and surrounded by colonnades, stairs and corridors.

The importance on the environmental level of color component is demonstrated especially by what remains at Knossos: a lively polychrome, now mostly lost, only partly restored, enriched by frequent opening to the outside and the nature of the loggias and porticos with elegant wooden pillars in smooth trunk should taper down, circular, often painted red (sometimes fluted vertically or spiral), supporting with the widest part, the upper one, capitals pulvinus, or cube. The walls were painted, with various techniques; one consisted of the fresco technique itself; the other technique was to apply the colors on the plaster dry. Finally a particular technique is the inlay, which is to cut out, from the dry plaster, parts to decorate, which were then filled with fresh and colorful plaster.

It must be emphasized that in the frescoes figures of men and women, bulls and griffins, shaped in bas-relief, are often represented in real scale, as was the case in Egypt; technique that is probably stated between 1550 and 1470. Just the colors used, very lively and strong, both in the exterior and the Interior, and easy to fact: red, ochre, black and blue, reinforced by the contrast with the green of the surrounding landscape and equally bold colors of sky blue, in immediate contact with the building, and with the rocky soil crisp clear sound component.

The subjects of Cretan wall painting, especially at Knossos, are often scenes of life: scenes of athletic games, ritual dances, religious ceremonies or personages, willing to profile, elegant and dignified, where there is the presence of sharp boundary lines marked by evident influence by Egyptian art, whose typical patterns seem to be inspired by the setting of the figure, with a three-quarter bust or opposite, the most representative view, legs in profile, to indicate a space in the proceeding solemnly in profile, but with an eye in front, that which gives maximum expression.

Another feature of these figures is chromatic differentiation, with dark skin color for men, and clear for women; a practice that also seems often used to distinguish the ethnic (Asian or African) origin of the figures, such as in the ritual scenes of the painted sarcophagus found at Haghia Triada, and in the palace of Knossos; a practice often used also in Egypt. 


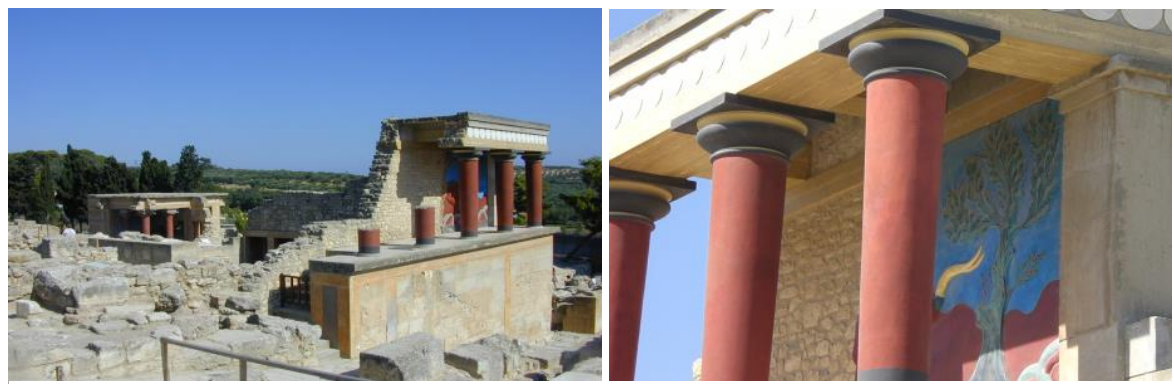

Figure 23. The Lively Polychromy in the Interior and Exterior, although Consisting of a few Colors, it Creates a Highly Harmonious with the Colors of the Natural Environment, which are also Strong and Shiny. The «Bastion Porch» at the Northern Entrance of the Great Palace, and the Detail of the Fresco with the Bull

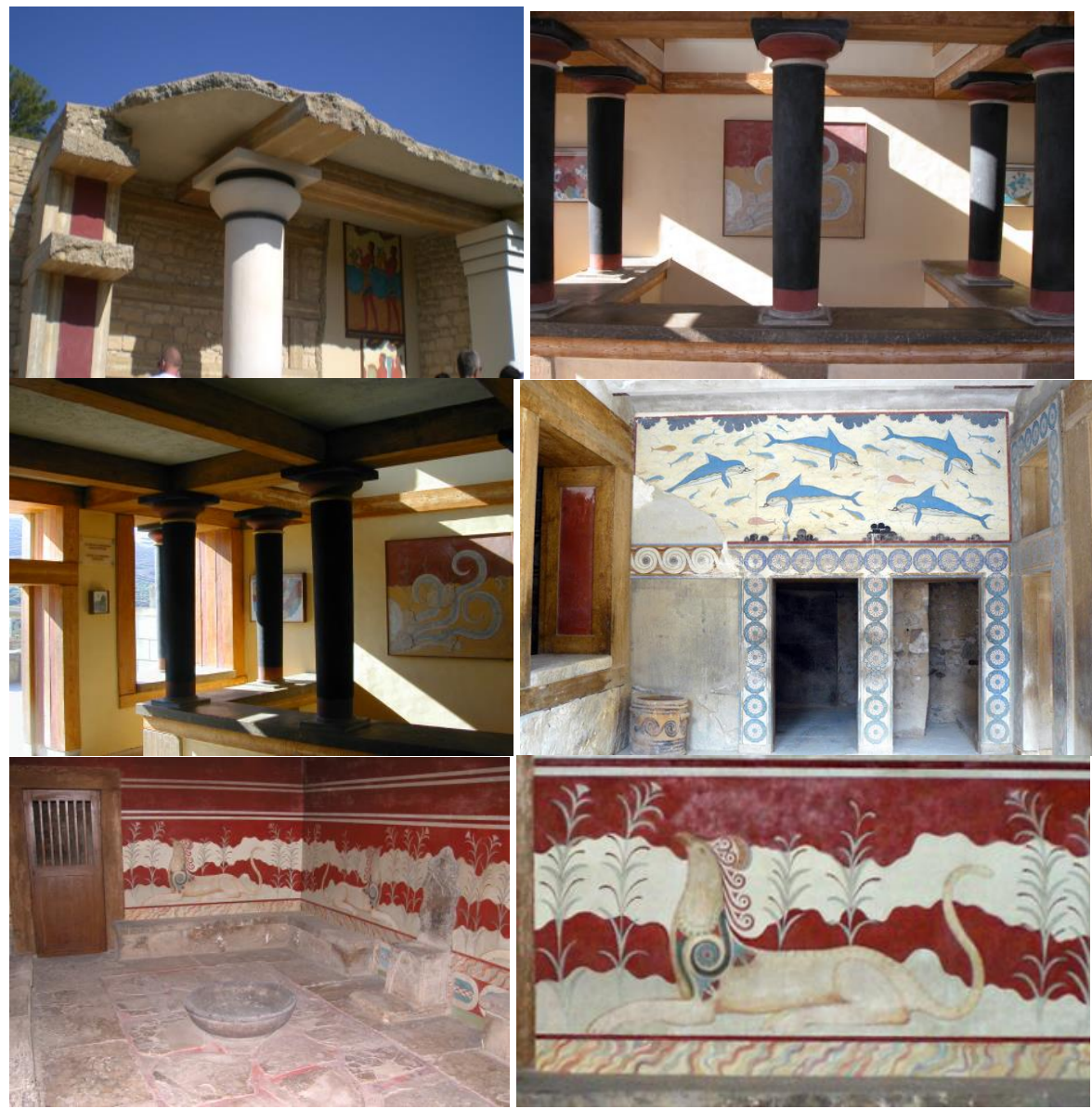

Figure 24. The Interiors. West Wing; View of the Remains of the Monumental Propylaeum. Beside and under are the Colonnades of the Peristyle which Leads to the King's Megaron and at Queen's Hall, Painted with Geometric Motifs and Naturalistic (Dolphins). Under is the Throne Room. The Frescoes Depict Pairs of Heraldic Griffins, Facing the Throne, Yellow on Red Background in front of a Palm Tree, according to the Mycenaeans' Taste. Assembly and Detail

Another reference to the Egyptian culture still originates from the palace of Knossos where, in the hall of the six columns in the upper floor of the western part was the fresco representing a moment of court life, with young ladies sitting on 
folding stools, dressed in refined clothes (fresco of the Blue Dames), among which the female figure called the «Parisian» stands out. This fresco has been compared to similar Egyptian depictions of the New Empire, in an outdoor banquet scene.

The rich also interior decoration: halls with colored marble-floors, friezes above doors, walls lined with alabaster and colorful paintings clogs (red, yellow and blue: the primary colors or pure), together with black and white. The ornaments are both geometric patterns, such as spirals, cables, waves, circles, both architectural backgrounds in colonnade, or figurative, with, in addition to the figures, animals, flowers, plants, often inspired to the flora and fauna of the island: lotus flowers, lilies, crocuses, palmettes, or bulls, monkeys, partridge, but also marine subjects: fish, mollusks and shells on the island.

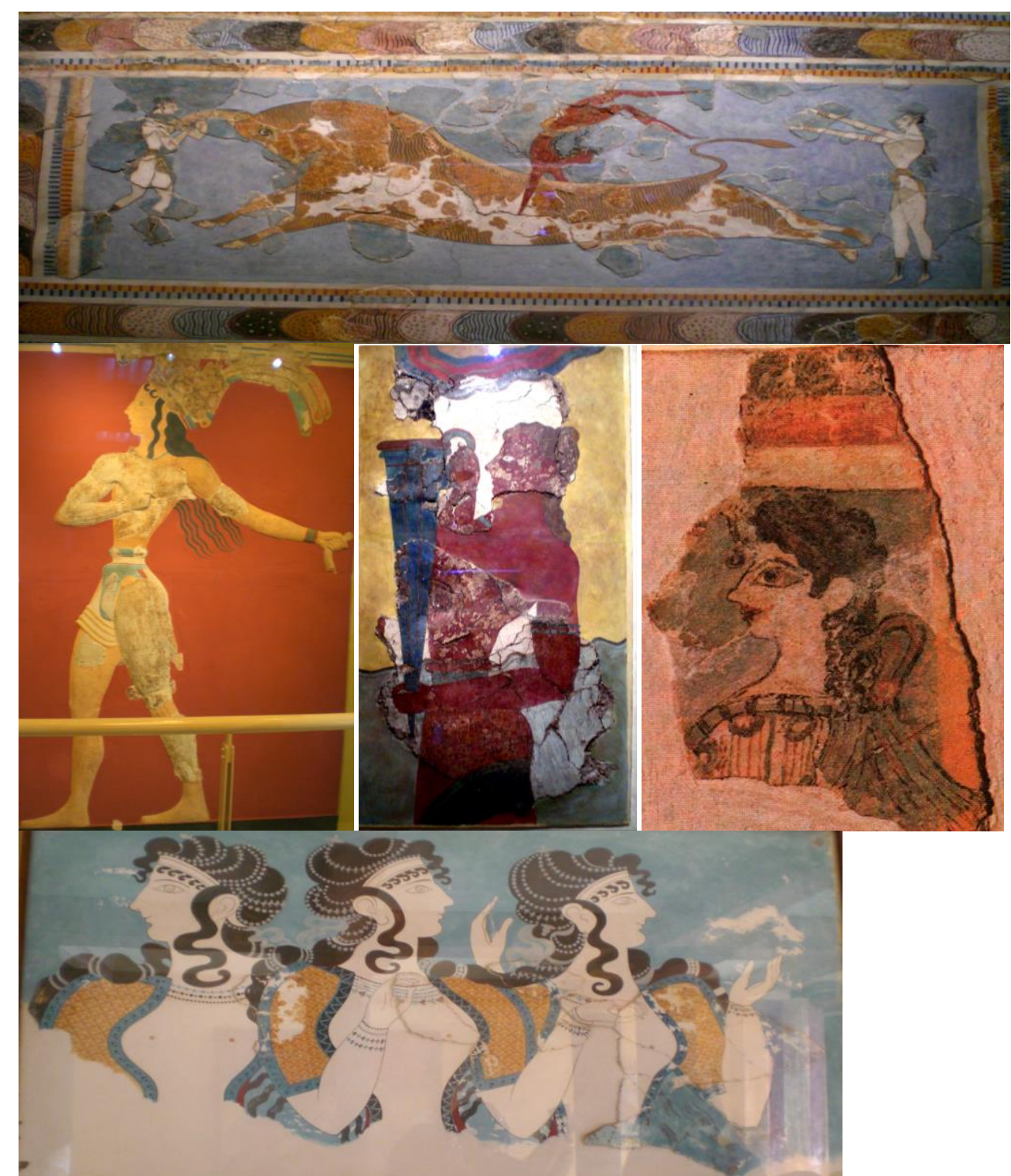

Figure 25. Museum of Iraklion. Bullfighting Scene Fresco, and Fresco of the Prince of the Lilies; Palace of Knossos. Fresco by Cupbarer with Rython. Female Figure known as «La Parisienne». Fresco of Blu Dames 

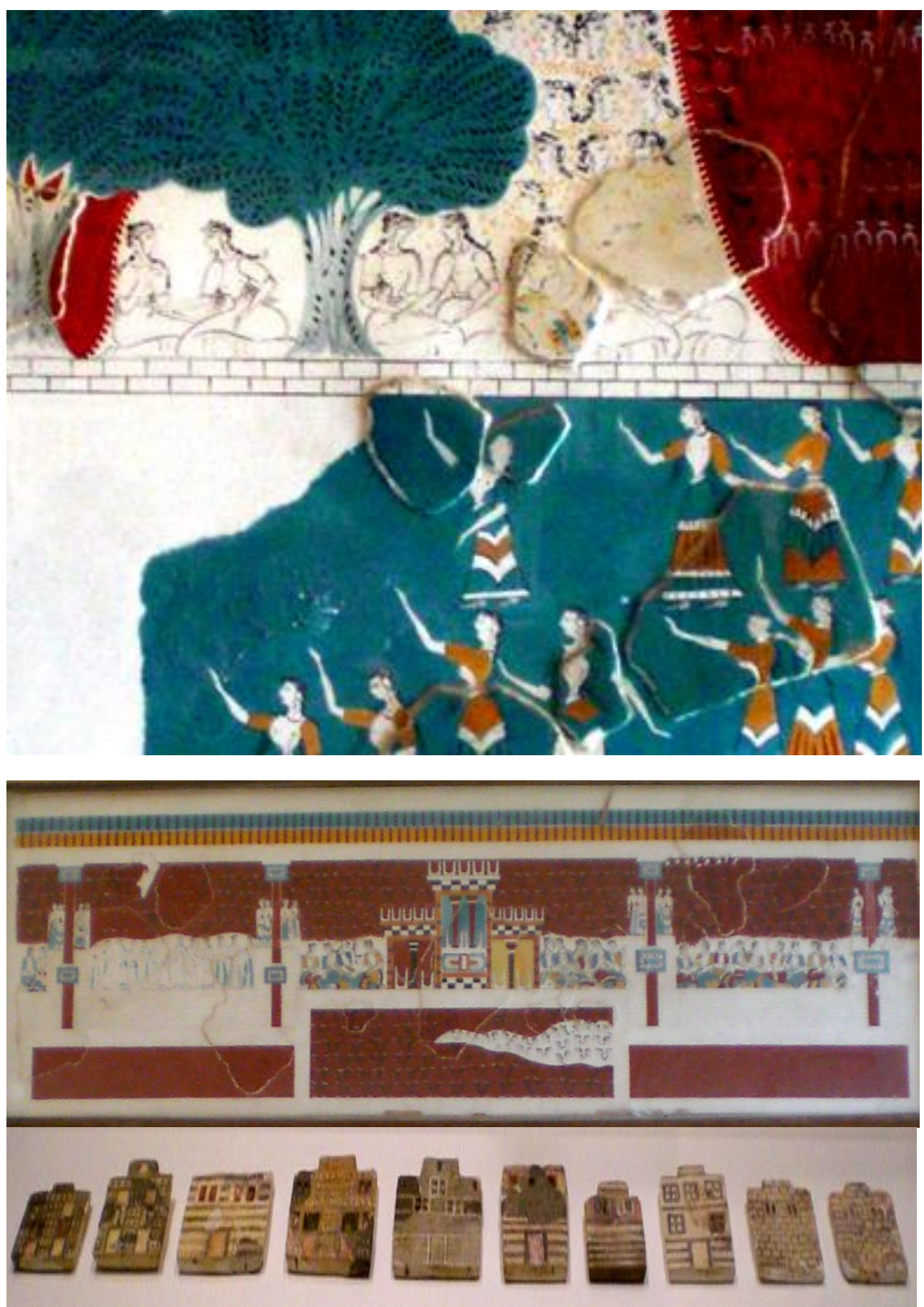

Figure 26. Museum of Iraklion. Fresco of the Sacred Wood Arts, showing a Suggestive and Bucolic Representation of the Natural Environment. Representation of the City, very Abstract and Symbolic Way, but the Representation of Architecture and Life in the City is very Precise (Under) Ceramic Tablets from the «House of Mosaics». Knossos. Period as the New Palaces (1600-1500 B.C.). Tablets depicting Mesominoiche Age Houses are very Realistic, with Doors, Windows, Floors and Decorative Building Elements, and Colors 
The scholars, for the post-palatial period, with the Mycenean Conquery and the destruction of the Knosso Palace, testified that the other sites (Kommos, Haghia Triada), deep the exchanges with Cypro and the Syro-Palestinian territories.

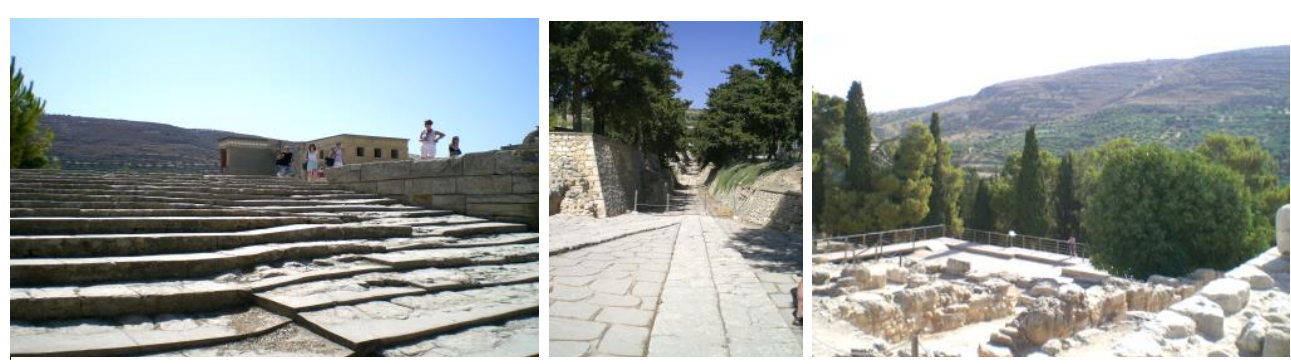

Figure 27. The Colours of the Natural Environment and Local Stones Dot the Landscape where it is Placed, Harmonically, on Top of a Hill, but not Far from the Sea, the Building, in an Area along the Landscape of the Area. Theater's Area. From this Point is developing the Regal Lastricated Road

Around the Grand Palace are other mansions and aristocratic residences, including the «House of the frescoes», located near the porch steps to the South of the Palace of Knossos, unassuming, but where there are multiple layers of valuable fragments of frescoes, where monkeys and blue birds are also represented. In another room were found fragments of vases rituals with double axe drawings.

In Mycenae, the spread of Cretan art on the Greek mainland is already around the $17^{\text {th }}$ Century B.C., perhaps as a result of the close trade relations between the two peoples, documented by numerous items of Cretan production found in Mycenaean area. In the tombs of the ancient Mycenaean period many items of Cretan production were also found, which perhaps served as models for their nascent craftsmanship.

On the other hand also by the discovery of Egyptian artifacts at Mycenae and the Mycenaean pottery in Egypt testifies to relations with the latter country during the New Kingdom.

And if the repertoire of Mycenaean decorative motifs reveals the clear Cretan derivation, many iconographies and figurations show the inspiration to more distant models, typical of Middle Eastern artistic cultures.

While the scant remains of wall paintings, from topics such as treasure hunts, wars, religious ceremonies, the most basic and Cretan painting styles show schematic. In the late Mycenaean period (1400-1100 B.C.), the new palaces, which definitely fortified, enriched by extensive interior richly decorated with reliefs with «Megara», polychrome marble and murals, they appear again pleas Cretans as octopuses, dolphins, bullfighting hunts and ceremonies, but most often reduced to pure compositions schematic stylizations.

Unlike the other palaces (Mycenae, Thebes, Orcomeno), from the great palace of Nestor in Pilo ruins (Messenia), splendid frescoes and painted stuccos have emerged from the excavations, which, although only by fragments, testifies the original luxurious mural and floor decoration, so much so that, some scholars 
put forward the hypothesis on the Minoan character of some solutions of the first palace of Pilo.

Especially in the representation of the gigantic bull in a procession of bearers of gifts represented in the frescoes of the room in front to the hall and in the scene of the bull offering present in the megaron hall; in the representation of the griffins associated with two lions at the bottom, that are facing by heraldic. They reminiscent of those in the Knossos Room of the Throne; in the representation of winged griffins similar to those that adorn the eastern hall of the Palace of Knossos.

Moreover, scenes depicting sacrifices of bulls and banquets were customary in the Cretan and Near East frescos. A bull sacrifice is represented in the sarcophagus of Haghia Triada; processions of bearers of gifts accompanying a bull to the sacrifice, are painted in the frescoes of the Palace of Zimri-Lim in Mari, in the Egyptian palace of the New Kingdom in Malkara, and in the Palace of Knossos. ${ }^{12}$ In the early $12^{\text {th }}$ Century you experience the collapse of Mycenaean civilization.

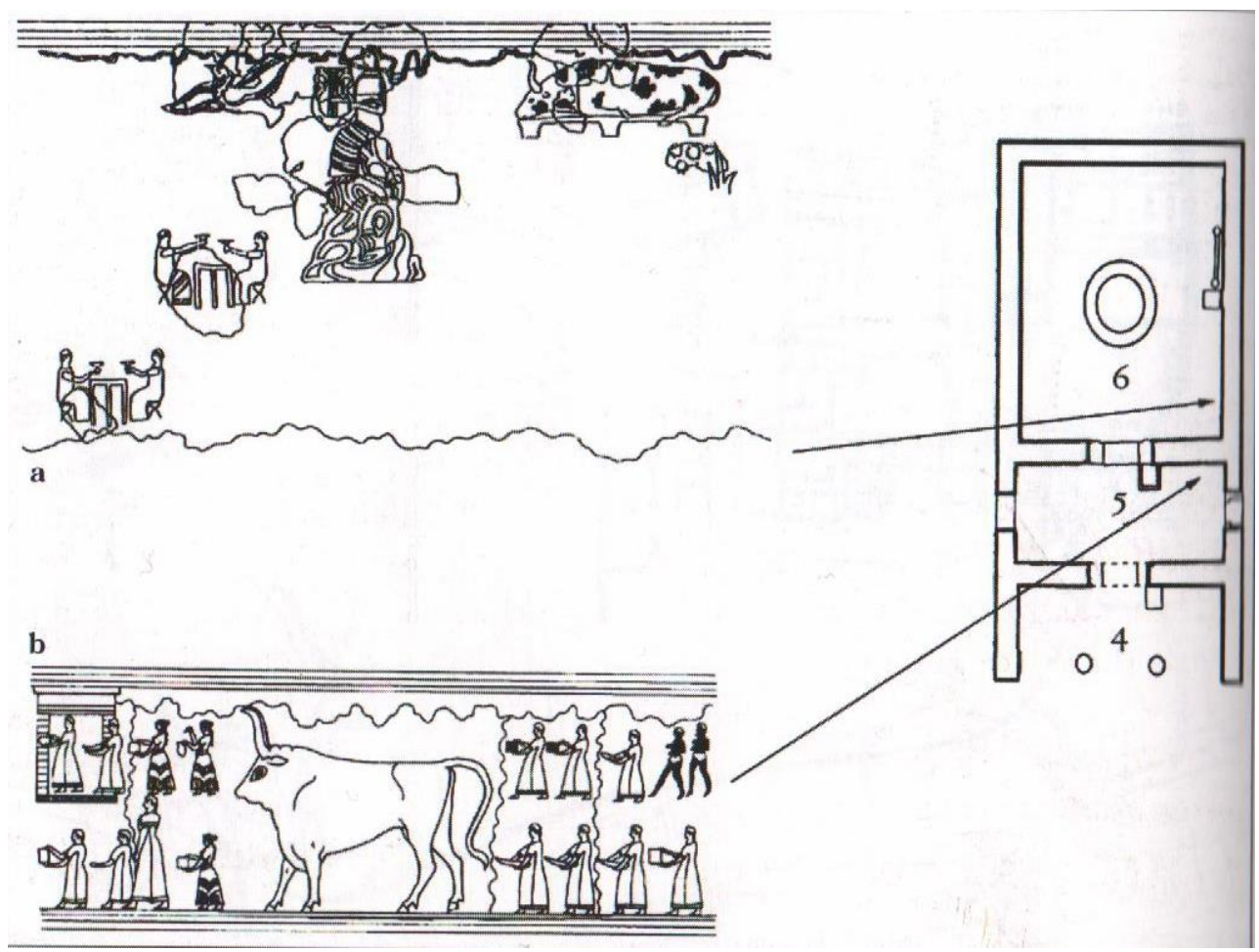

Figure 28. Reconstruction of Frescoes in the Palace of Nestor in Pilo Source: Ciotta, 2013, fig. 223.

12. Ciotta, Architetture Egee. Momenti di Culture Variegate e Premesse alla Civiltà Greca, 2013. 


\section{Colors and Decorative Features in Greek Civilization: Use and Characters}

The Temple

In the Greek world the polychromy is used both in protective and decorative function, as on top of temples to protect wooden structures from the ravages of time and weather, continuing even with the use of stone building materials (sec. VIII-VII BC) and marble (from the $5^{\text {th }}$ Century B.C.). From the $5^{\text {th }}$ Century, the few colors till then in use-black, brown, yellow, blue and reddicromie are added as red and light blue, or green and red, contrast between complementary colors, to mark the various parts of the building and decorative elements.

The Greek world expresses the most taste for color in the temple; the color highlights the constituent parts: the column (stem and capital), the entablature and pediment; and decorative ones, the moldings. But while the columns often have bright colors, both of stone materials constituting and from the colors applied, are above all the decors of the entablature and pediment of constituting significant element, both in terms of color, as figurative that are sculptural cycles, painted with figures of gods, scenes and narratives of Greek mythology. Also the walls, mainly external, are often painted with figures of gods, often to gigantic size, heroic scenes or scenes of Olympus. So the colour is an important part of the architecture, which points out in its parts, and it operates an articulation for contrasts, often with few colours - blue, green and red and ochre.

Few but definite traces remain of this practice, on which has developed a very broad debate in the $19^{\text {th }}$ Century; practice documented by surveys of the many Pensionnaires of the Academy of France in Rome, representing the Greek temples throughout the nineteenth century, until the early $20^{\text {th }}$ Century, with a chroma key sometimes perhaps too pronounced in the excessive zeal of the discovery of the color. These testimonials, are rich and numerous, are confirmed by the numerous tracks on objects that can be seen in Museums, which show even today the fundamental function of color for the purpose of 'architecture', in the temple, but also in all other artistic expressions: sculpture, and painting, and in building materials, buildings and urban spaces. That is, color is fundamental in the Mediterranean world, and in particular in Greece where all the artefacts receive completion and meaning through the use of color. Just visit the Museum of Athens to realize it. On almost every artifact there are traces of the colors that completely covered every surface. 


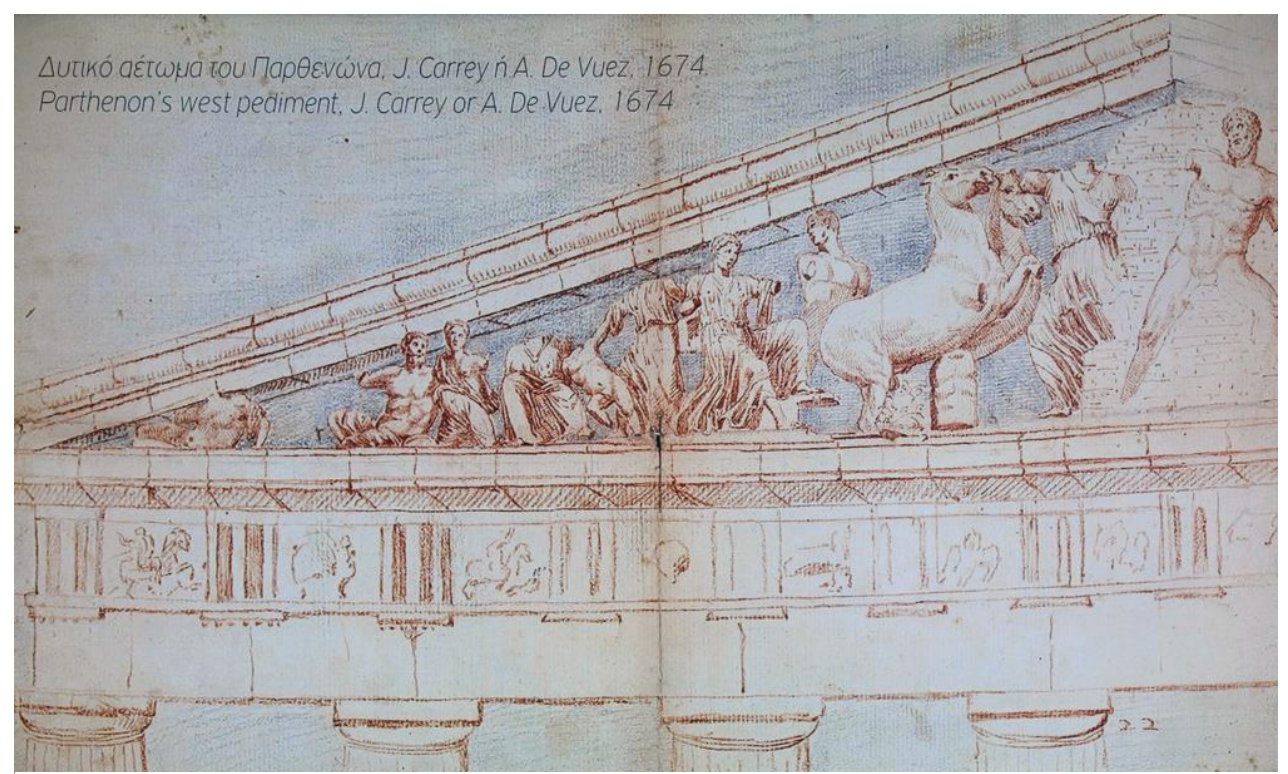

Figure 29. J. Carrey or A. De Vuez. 1674. West Pediment of the Parthenon. Drawing. The Blue Background is Evident, from which the Sculptures Stand Out Source: Author (2017), from a Video in the Acropolis Museum, Athens.

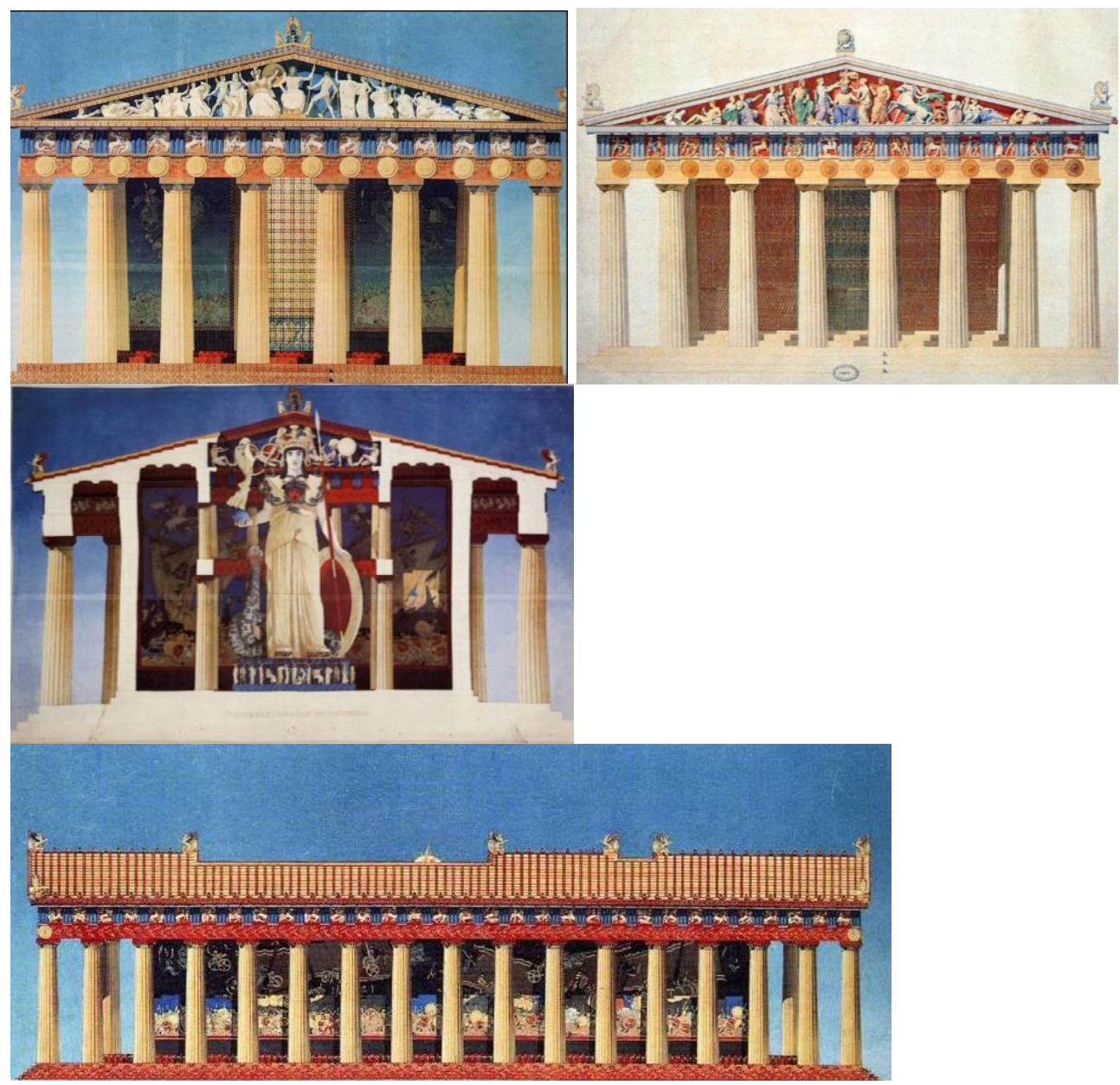




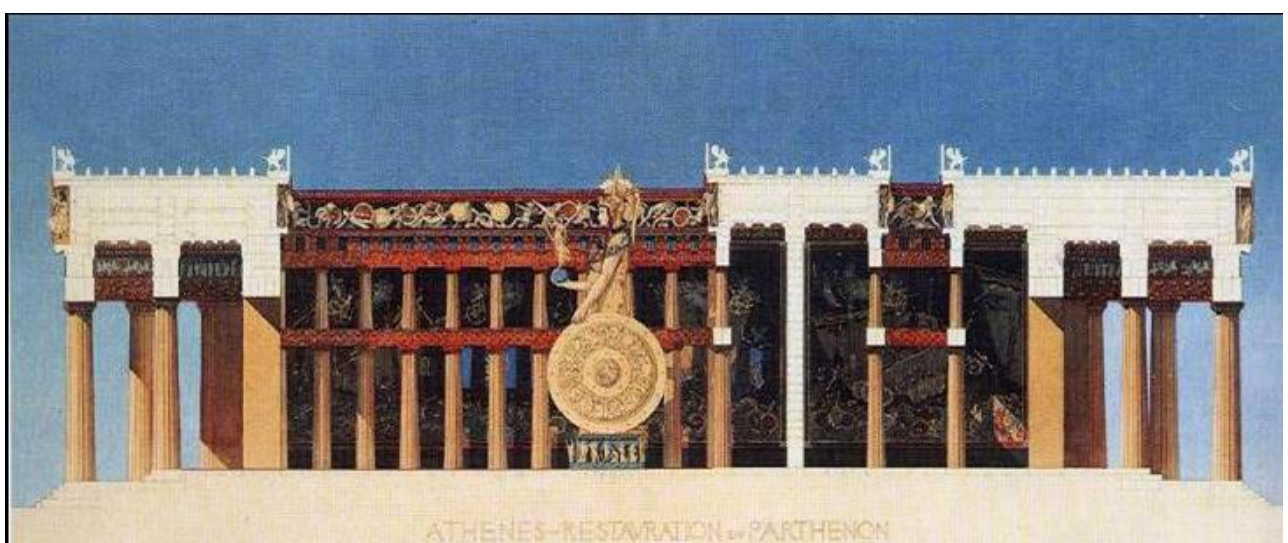

Figure 30. (From the top) Loviot, B. Reconstruction of the Main Facade of the Parthenon, 1879-1880 (Paris, Ecole National Supérieure des Baux-Arts). Kluger, F. Reconstruction of the Entablature of the Parthenon, 1835 (Athens, Gennadios Library). Paccard, A. Reconstruction of the Eastern Façade of the Parthenon, 1845-1846, (Paris, Ecole National Supérieure des Baux-Arts). Loviot, B. Parthenon. Cross Section, 1879-1881. B. Loviot. Reconstruction of the North and Prospectus of the Longitudinal Sections of the Parthenon, 1879-1880 (Paris, Ecole National Supérieure des Baux-Arts)

Source: A. Ciotta, 2008.
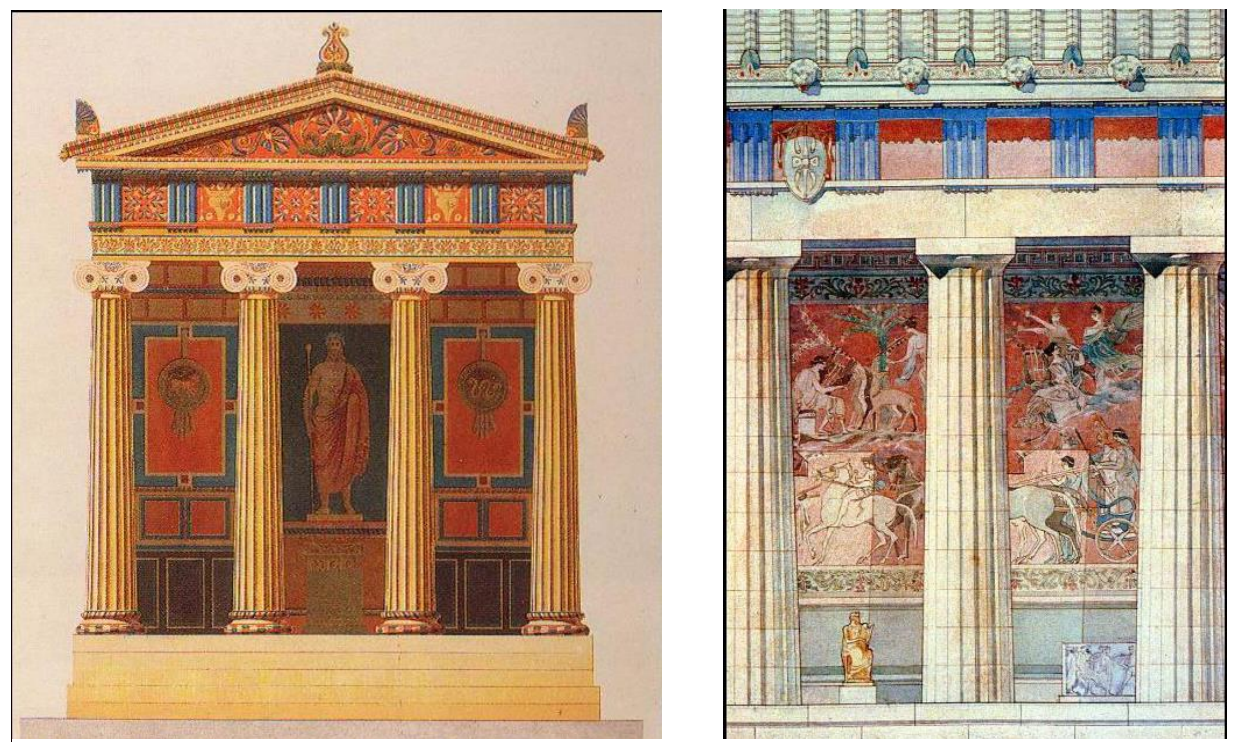

Figure 31. J. I. Hittorff. Reconstruction of the Façade of the 'Temple of Empedocles' in Selinunte, 1851. A. Touraine, Detail of the Temple of Apollo at Delphi, 1894

Source: A. Ciotta, 2008. 

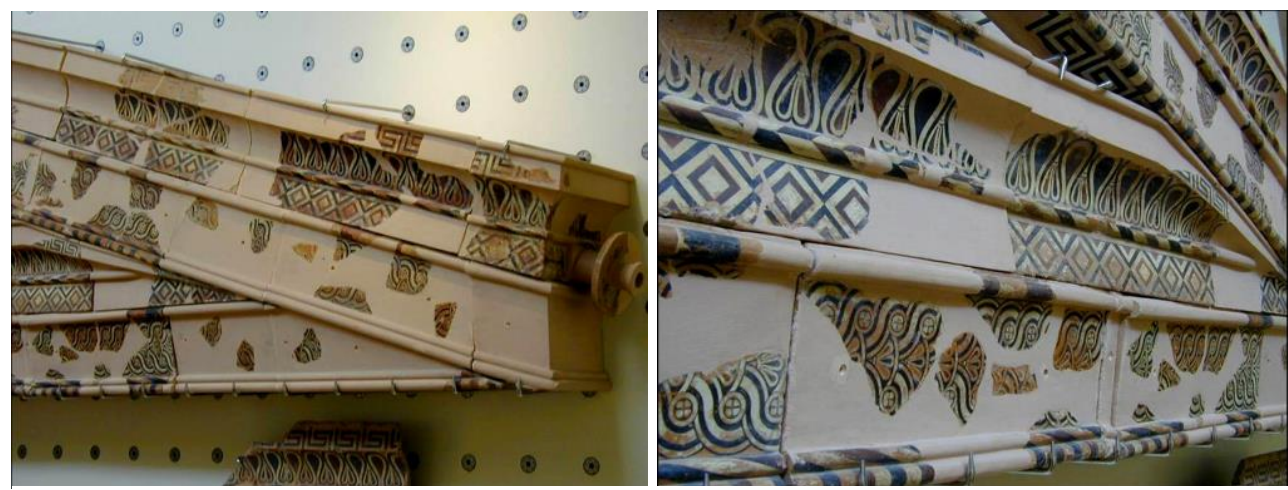

Figure 32. Olimpia. Pediment of the Treasure of Gela (Archaeological Museum at Olympia). Details of the Decorations Paintings of the Mouldings Source: Photographs by G. Ciotta, 2008.

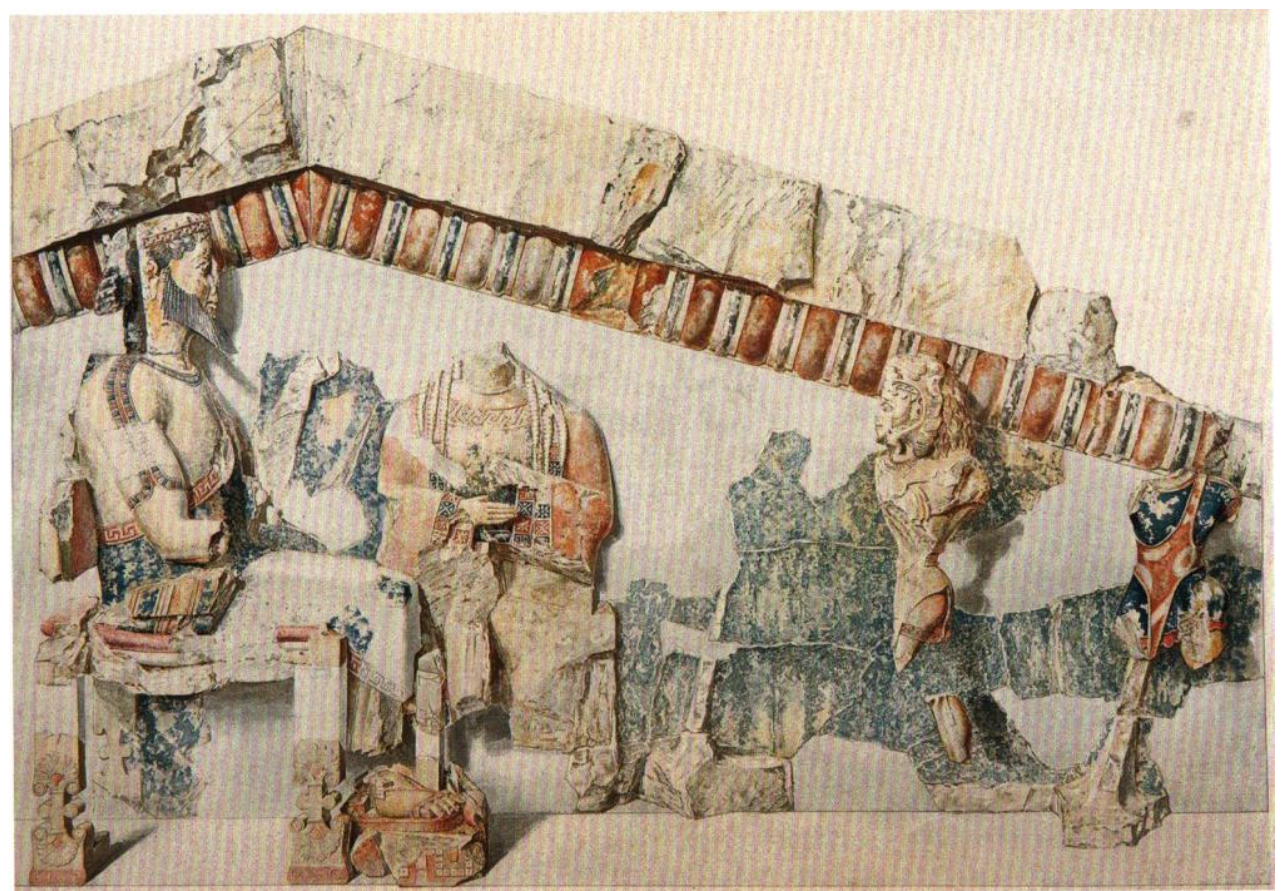

Figure 33. Archaic Pediment Sculptures. One of the 'Small' Pediments, Recomposed from Fragments found in the Acropolis Excavation, with Evident Traces of Color. Represented is the Apotheosis of Erakles, whit Hermes behind him

Source: Acropolis Museum Guide. Acropolis Museum Editions. Athens 2016. Graphic Rendering, Color. P. Valavanis, 2014, 39. 


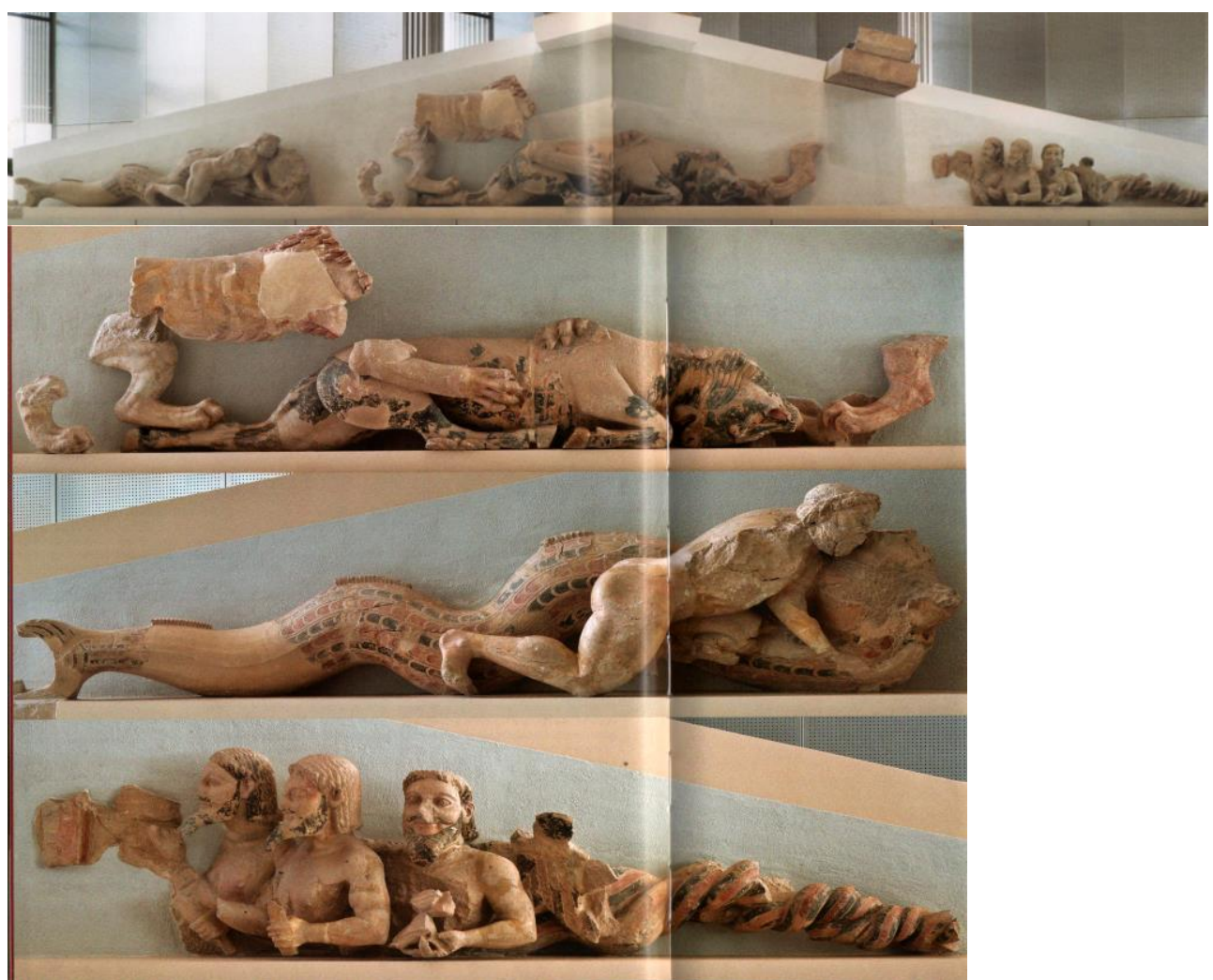

Figure 34. Athens. The East Pediment of the Great Doric Temple of Athena Poliàs. (Parthenon Archaic). About 570 B.C. Acropolis Museum.The Poros Limestone Pediment Consists of Tree Ensemble. In the Middle are Two Opposed Lions Attacking a Bull, at the Left Edge Herakles Wrestles with a Sea Creature, Nereus, and at the Right Most Probably Zeus, whose Figure is Lost, Struggles with Typhon or the Three-bodied Daemon, a Creature whit Three Winged Torsos and Serpentine Tail. A few Colors but Lively Show the Total Lively Polychromy of Sculptures

Source: Acropolis Museum Guide. Acropolis Museum Editions. Athens 2016.

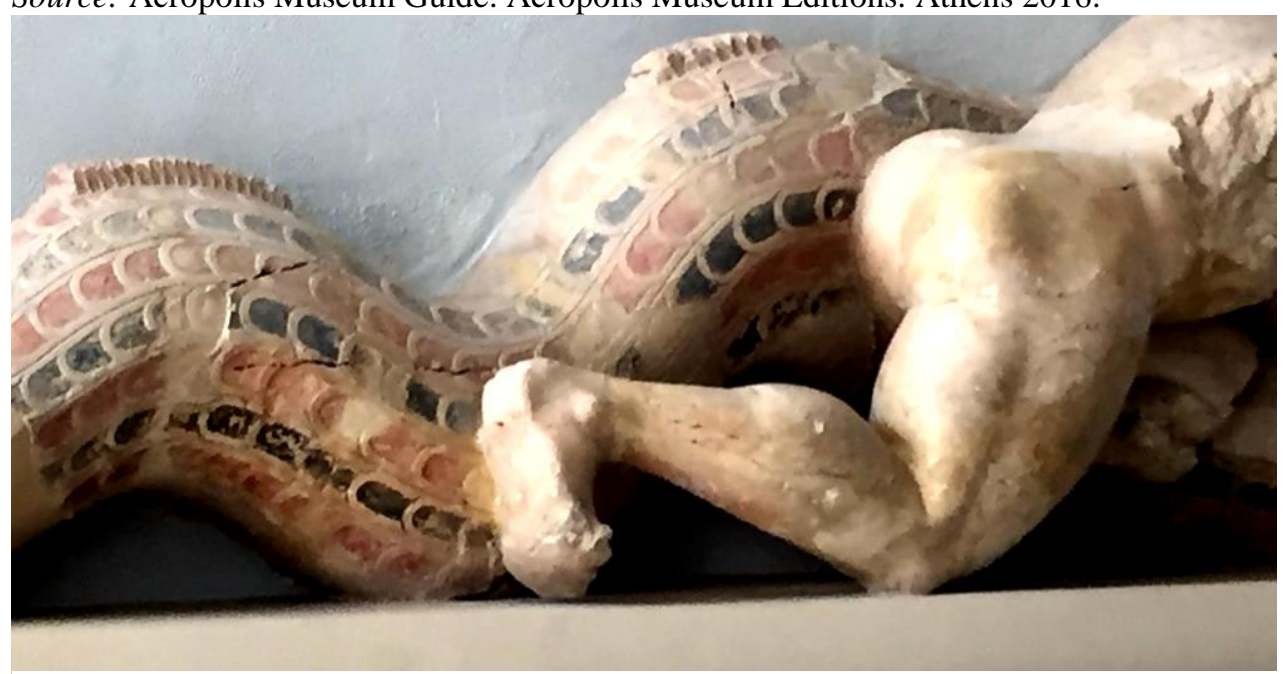

Figure 35. Detail of the Treatment in Polychromy of the Scales of the Newt Source: Photograph by Author. 


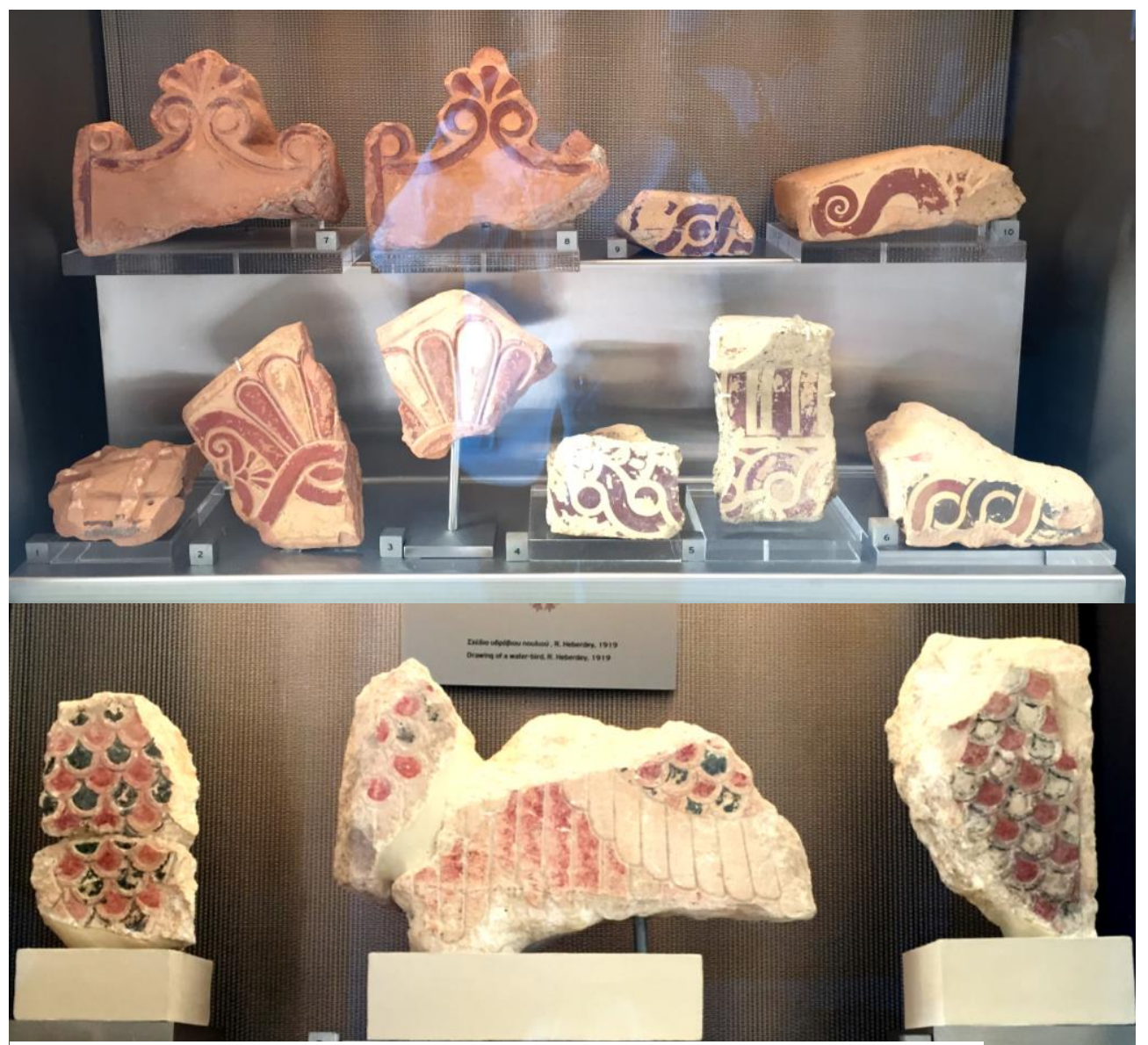

Figure 36. Acropolis Museum. Decorative Parts of Temples, Preserved in Classic Greek Decorative Shapes, Painted, very Elegant, in a few Simple Colors. Scale Motifs, Wave-bound Discs, Spirals, Petals Source: Photographs by Author.

Colors and Coloring Matters
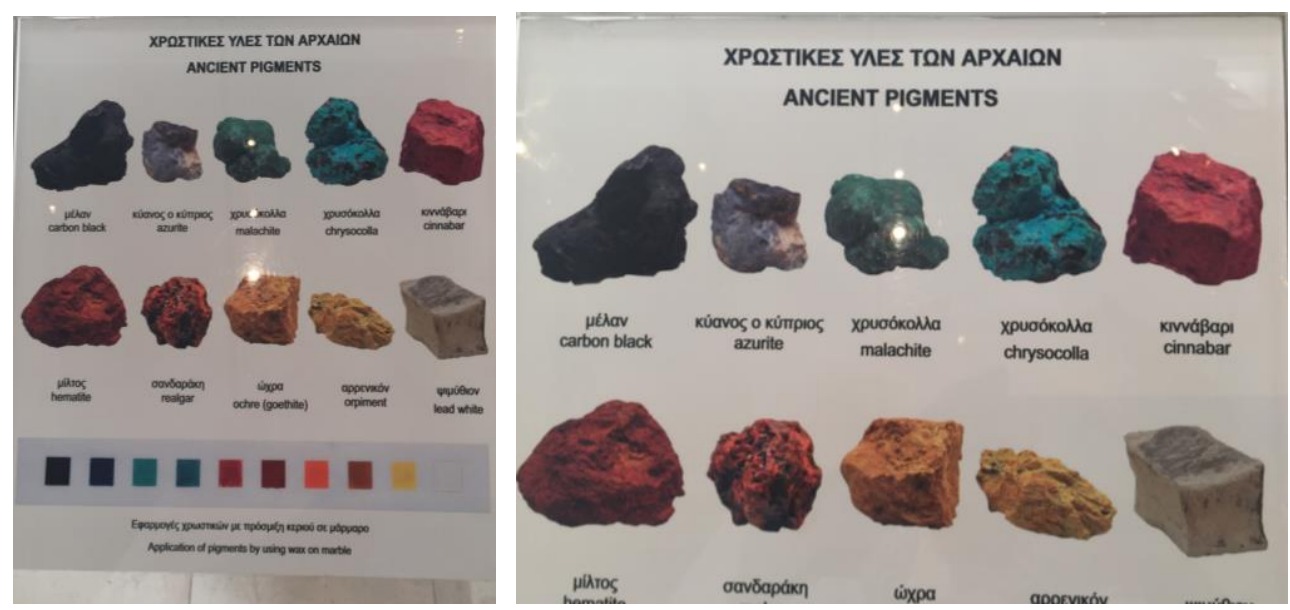


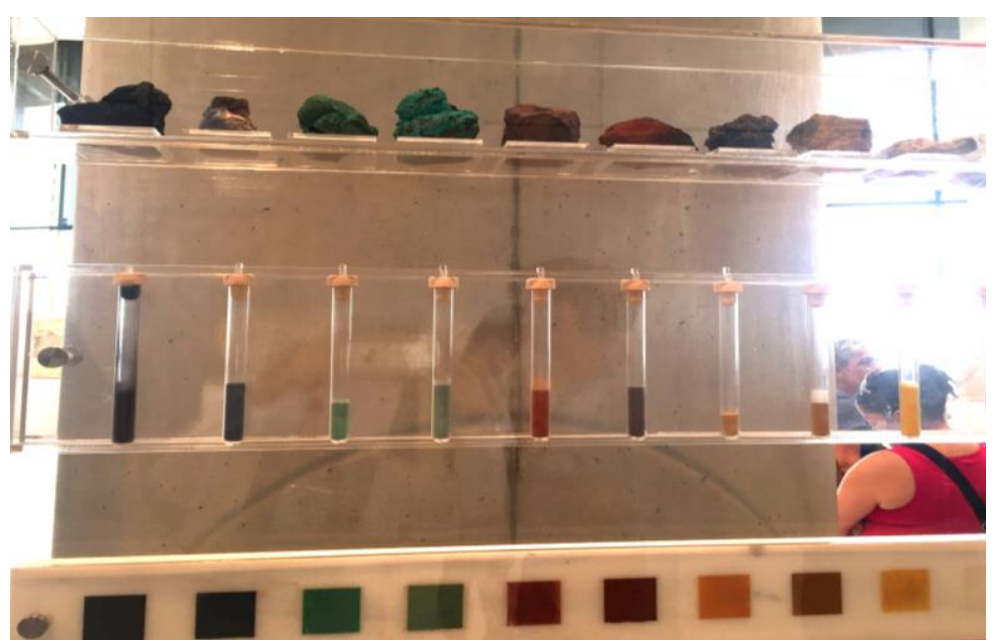

Figure 37. Acropolis Museum. Panel with the Ancient Pigments and Colors Source: Photograph by Author.
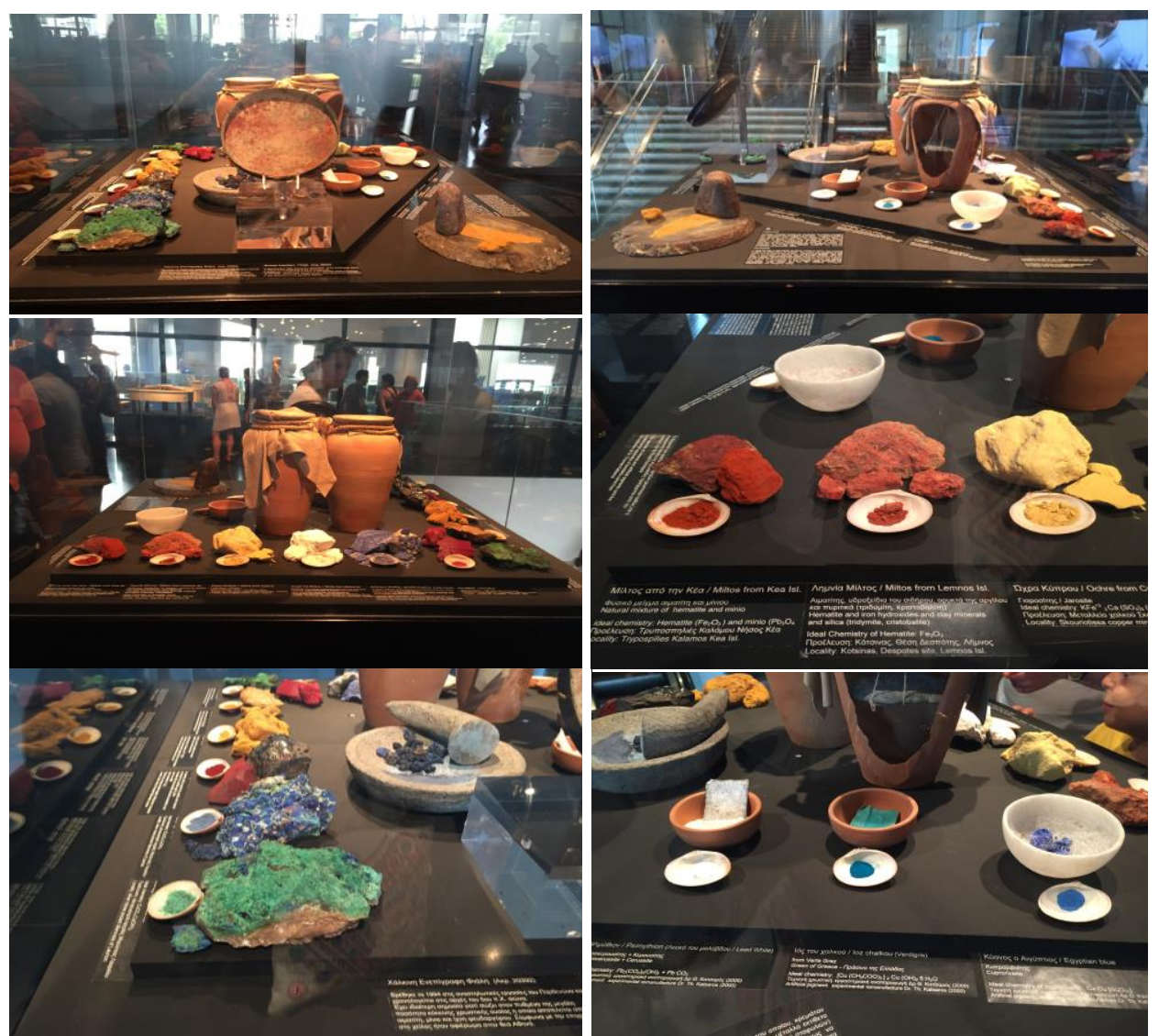

Figure 38. Acropolis Museum. Exposure Samples of Colors: Ranging from Minerals to Pigments made with the Old Tools

In the civil architecture, documenting this practice throughout Greece, rather than exhaustively in his strong chroma key, which often refers to the nobles, with the design and color, is the architectural type color treatment, imitating colored marbles, testified in the portion of the wall, reconstructed, preserved at the 
Museum of Pella (Macedonia), referring to the $4^{\text {th }}$ Century B.C., and the reign of Philip II (359-366). An extremely important document, which testifies to the connection between architecture and color, which has already reached a high level of culture and achievement. The same Macedonian tombs testify to the use of wall paintings and figurative scenes, already in the second half of the $4^{\text {th }}$ Century B.C., the golden era of Greek painting, when the color enters forcefully into the definition of surfaces of temples, the construction of important buildings but also minor.

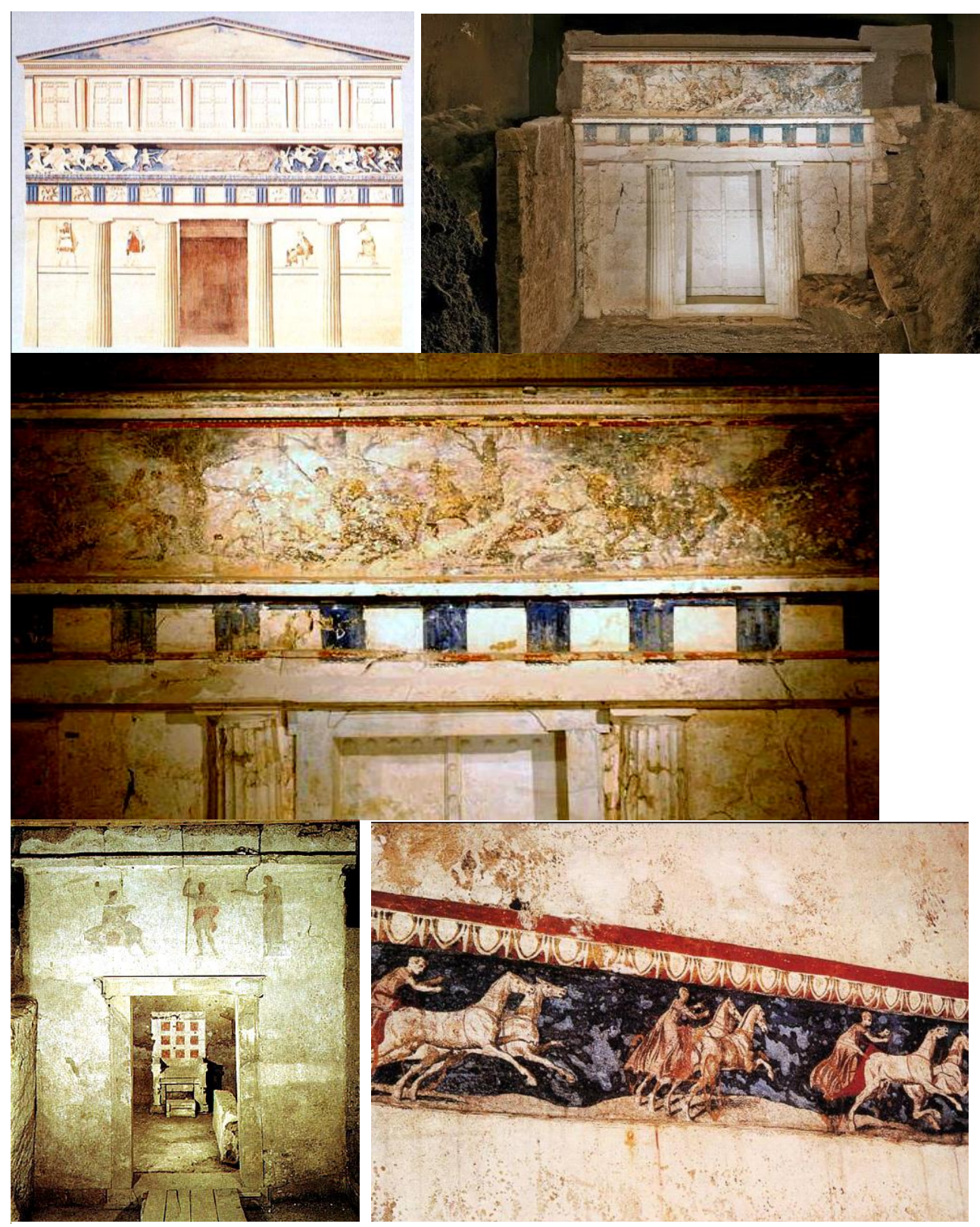

Figure 39. Vergina. Macedonia. Tombs of the Macedonian Kings. LefkadiaMiéza. Reconstruction of the Façade of the Great Tomb (Last Quarter of the $4^{\text {th }}$ century BC). Vergina-Aigai. Tomb of Philip II. Assembly and Detail of the Frieze Source: https://tinyurl.com/yc4pscmo Vergina-Aigai. Tomb of Prince. Painted Frieze of the Vestibule. 


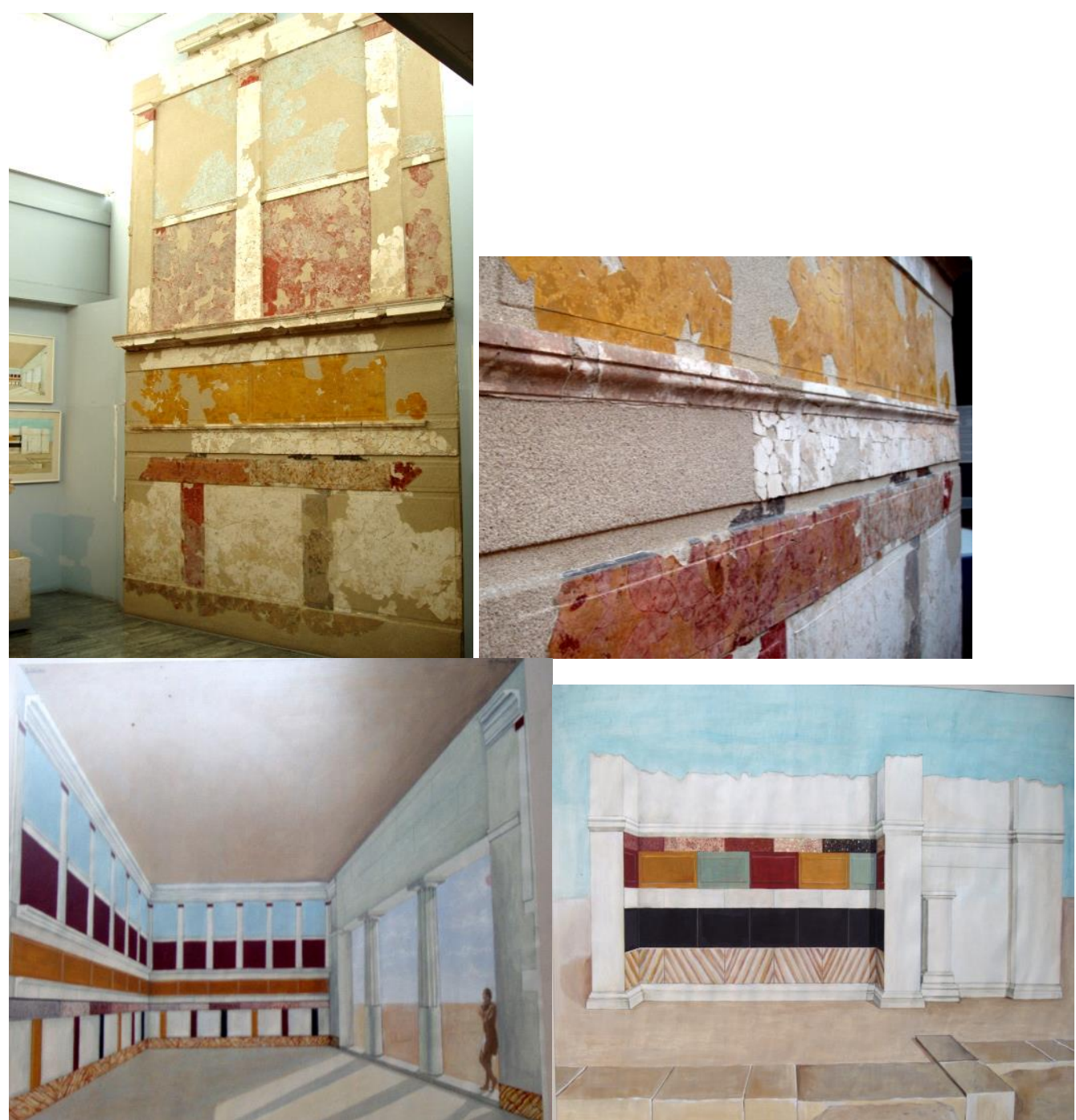

Figure 40. Pella. Macedonia. Museum of the Archaeological Site of Pella. (top) Recomposition of Portion of the Wall of the Dining Room of the House Called «House of Plasters», with Decorative Apparatus with Simple Architectural Stucco Frames, Horizontal and Vertical, Containing Panels with False Marble in Ochre, Dark Red, Light Blu and Clear Marble (below) Graphic Reconstruction of the House, Exhibited at the Museum

The Landscape and the Environment, Concerning the Chromatic Interaction of the Built with Spaces of Immediate Context, with Large Urban Areas, and Especially with the Shape and the Characters of the Surrounding Area; in addition, the Impact of the Built Environment

For the theme to the landscape and environment, the survey, different levels of reading, examines this relationship in the Greek world, the cases documented by pictures sent from France, the $19^{\text {th }}$ Century's copious Pensionnaires until the early twentieth century. This report is well highlighted and expressed in representations of great landscape and environmental value of «Envois», mails 
and packages. In fact, at all scales, as already the binomial environment and built both acknowledged as inseparable, particularly as sites of worship draw their expressiveness not only by geographical and environmental values of the land, to which they relate form and insert mode, but also by mutual colors. The view of the Acropolis of Athens indeed captures the relationship between the shape of the territory and settlement, which is emphasized by colors: first cold ones, that is, blue sky and blue sea, against which rises the town, situated in the plain towards the sea, at the foot of the ridge on which you have raised, as on a stage, the Acropolis, whose colors are burned by the light: an extremely charming, unicum as still appears from the top of Lycabettus Hill.

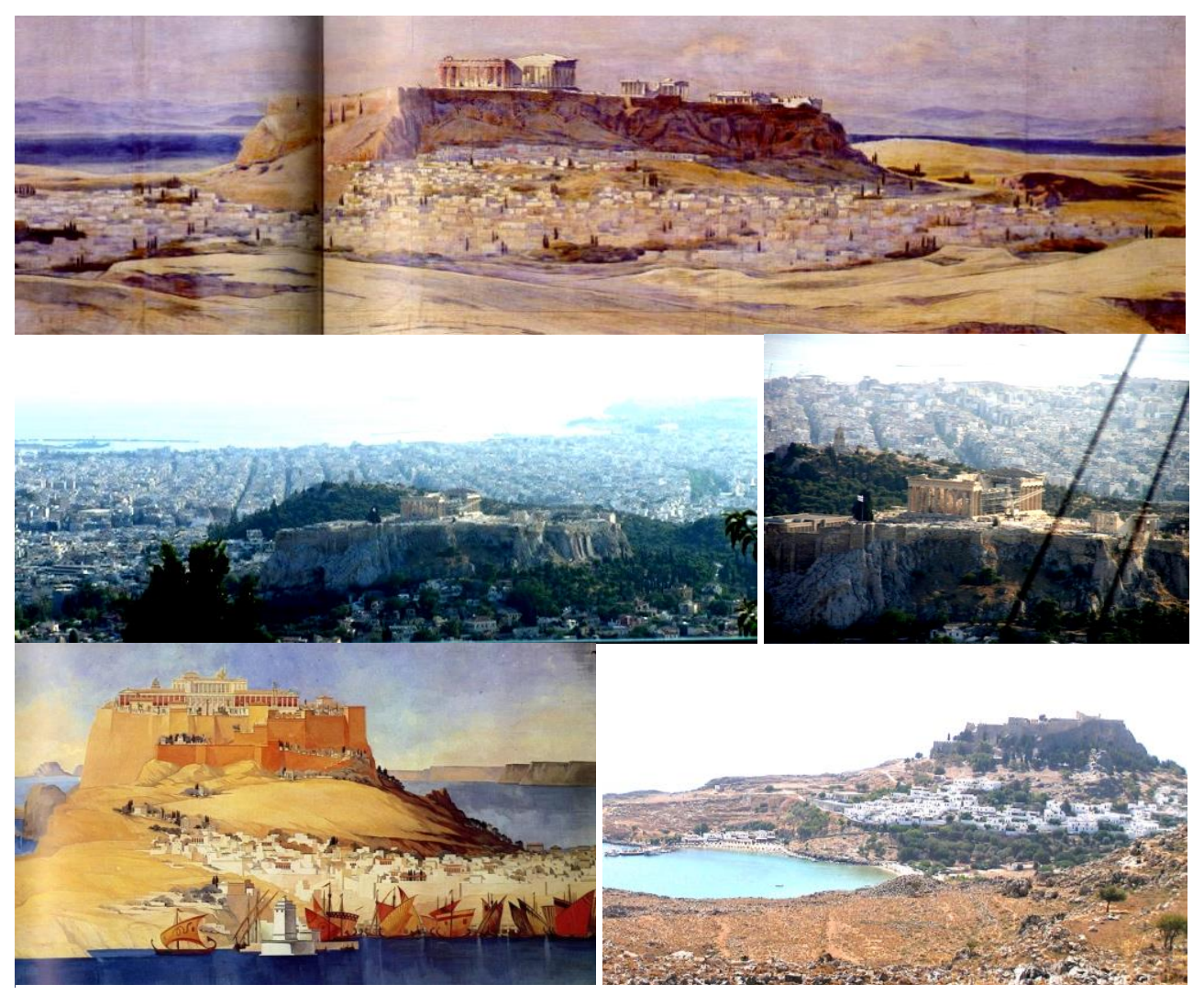

Figure 41. Athens. Acropolis. View from the North (Envoi of Nicod, C. 1912) Paris-Rome-Athénes 1982, p. 341 (Under) Acropolis. Current State. (Under) Lindos, Rhodes. Acropolis. Watercolour (Envoi of Domenc, P. 1936-1937) The Current Situation, Unchanged

In Lindos, Rhodes, the upward movement of the main whitewashed cubic houses, climbing from the port towards the top, stands still, among the few patches of green, still preserved in the landscape, marked by the Acropolis, whose profile ends and stands still significantly from the Hill, although its facilities are only partially preserved. The watercolor painting allows you to compare the situation at the beginning of the twentieth century with the current one, $20^{\text {th }}$ Century with the current one, pretty much remained intact, where in 
the built landscape and nature are coordinated in a harmonious relationship and respectful.

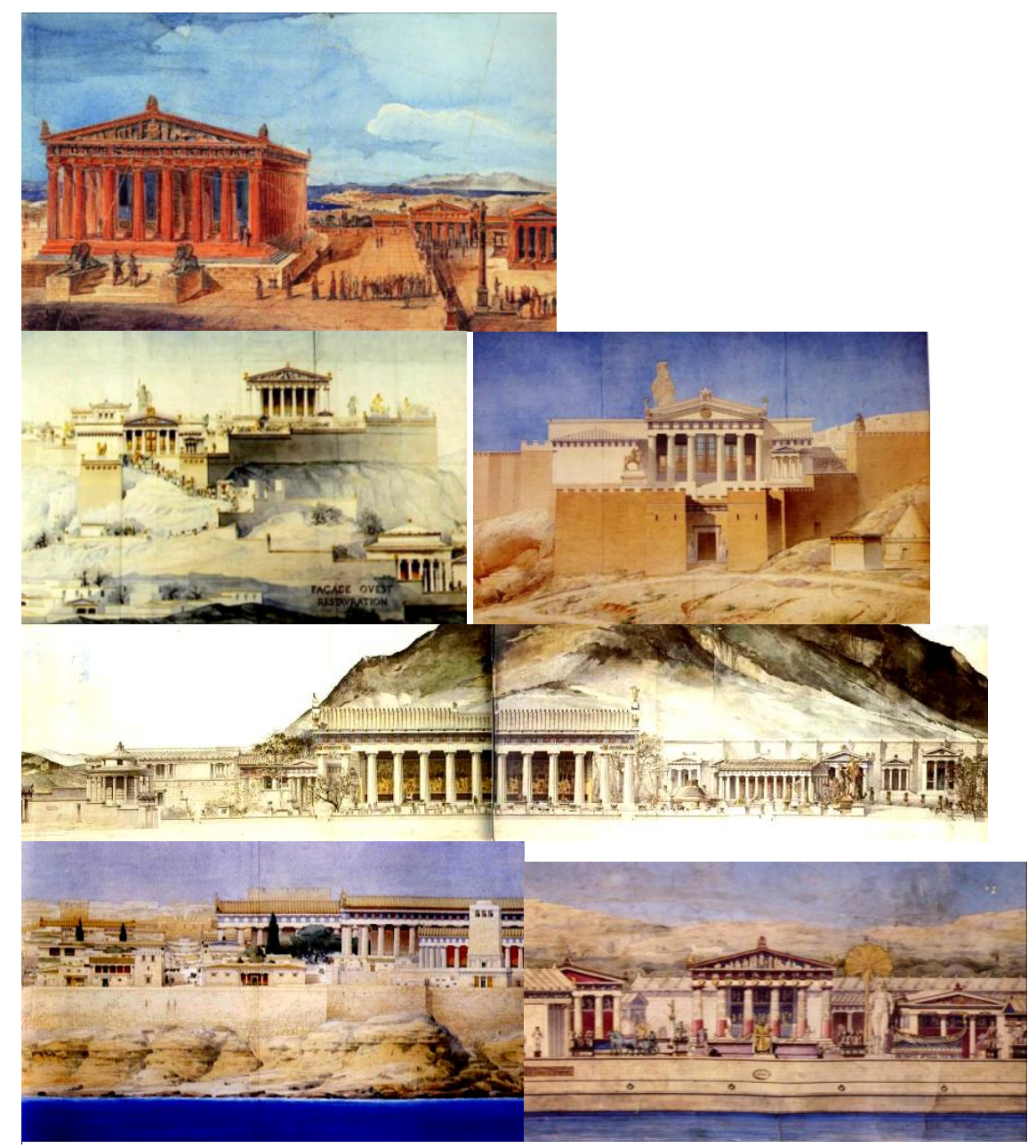

Figure 42. Athens. Acropolis (from the top) Athens. Semper. G. Reconstruction of the Parthenon, ca. 1834, Watercolor, (Zurich, Semperarchiv) (next) Western Façade (Envoi of Lambert, M. 1877, 7) Paris-Rome-Athénes 1982 p. 257 (under) Acropolis. East-West Sections of the Current Status and Restoration (Envoi of Lambert, M. 187) Paris-Rome-Athénes 1982 p. 255 (next) Propylaea. Western Façade (Envoi of Boitte, L. F. 1864) Olympia. View of the Sanctuary from the South (Envoi of Laloux, V. 1833) Epidaurus. The Temples. General View (Envoi of Defrasse, A. 1891-1893) (under) Selinunte. Acropolis. Restoration of the Southern Façade (Envoi of Hulot. J. 1904-1906) Delo. Sanctuary of Apollo. Prospectus (Envoi of Nénot, H. P. 1882)

For the closer distance other pictures documents the very important relation between built, territory, landscape, color, that did not escape to the scholars of the time. The high angle view, reconstruction of the Parthenon and its Esplanade; the prospectus in orthogonal projection of the complex seen from the sea; the overall East-West section, which relates the built the land slope, as the West façade of the Propylaea. Many representations show the inseparable connection between nature, 
geography and topography of the area, especially in the buildings of a religious nature. The striking landscape linked to the presence of water (sea, rivers, etc.) also serves as a symbolic element, in addition to contrast, the colors of the built, along with the sky always brilliant light blue.

\section{Colors and Decorative Features in the Etruscan Civilization. Use and Characters}

The Etruscan civilization, which dates back to the $11^{\text {th }}$ Century B.C. has a long period of development, with Apex around the $6^{\text {th }}$ Century B.C. The complex and rich paintings of Etruscan tombs of Cerveteri and Tarquinia testify this practice already from the $11^{\text {th }}$ Century B.C., and the development of Cerveteri culminates around the sixth century B.C. in relation to contacts with Greek culture and trade with the Phoenicians and Carthaginians.

This civilization begins its decline from the $5^{\text {th }}$ Century, until in the $3^{\text {rd }}$ and $2^{\text {nd }}$ Century B.C. gradually to it overlaps Roman. Also the history of the Etruscan town of Tarquinia begins in the late Bronze Age and early iron age (IX-X Century B.C.).

As for the paintings of the graves in the Egyptian civilization, even the numerous Etruscan tombs still retain, though they too much depleted, a remarkable and valuable heritage of wall murals, painted in polychrome, with architectural and decorative motifs and almost constant presence of figures and symbolic animals. Basically these are the two richest heritage wall painting preserved from antiquity.

The oldest documents of Etruscan painting are some clay slabs painted, perhaps intended to cover religious buildings or graves, with strong influences of ionic and Corinthian painting according to the five Slabs Boccanegra, dated to 550 B.C., found in Cerveteri.

Two of the plates relating to the Etruscan mythology, with two monstrous creatures of culture, highly decorative, the Chimera and the Mermaid, as well as the Centaur and the Gorgon, of Greek origin, but also the three plates of processional character, enriched at the base by coloured vertical bands and over disc pattern linked to wave, are of interest because they resemble the geometry of the Aegean world.

The important Etruscan centers of Cerveteri and Veii retain the oldest production of tombal painting cycles, like the Lion Tomb paintings in Cerveteri and the Tomb Campana in Veio, dating from the $6^{\text {th }}$ century BC, where there are influences of vase painting of Rhodes, in the grounds at palms and fantastic animals, along with those of the Corinthian and Ionic painting, constitute the main components of the archaic Etruscan painting (see below the Tomba dei Tori in Tarquinia).

The largest and most interesting documentation, starting from the middle of the $6^{\text {th }}$ century BC, is located in Tarquinia, where the graves of the $6^{\text {th }}$ and $5^{\text {th }}$ century BC show a qualitative and stylistic diversity, some related to the simultaneous presence of local artists and of Greek origin, then outdated. 


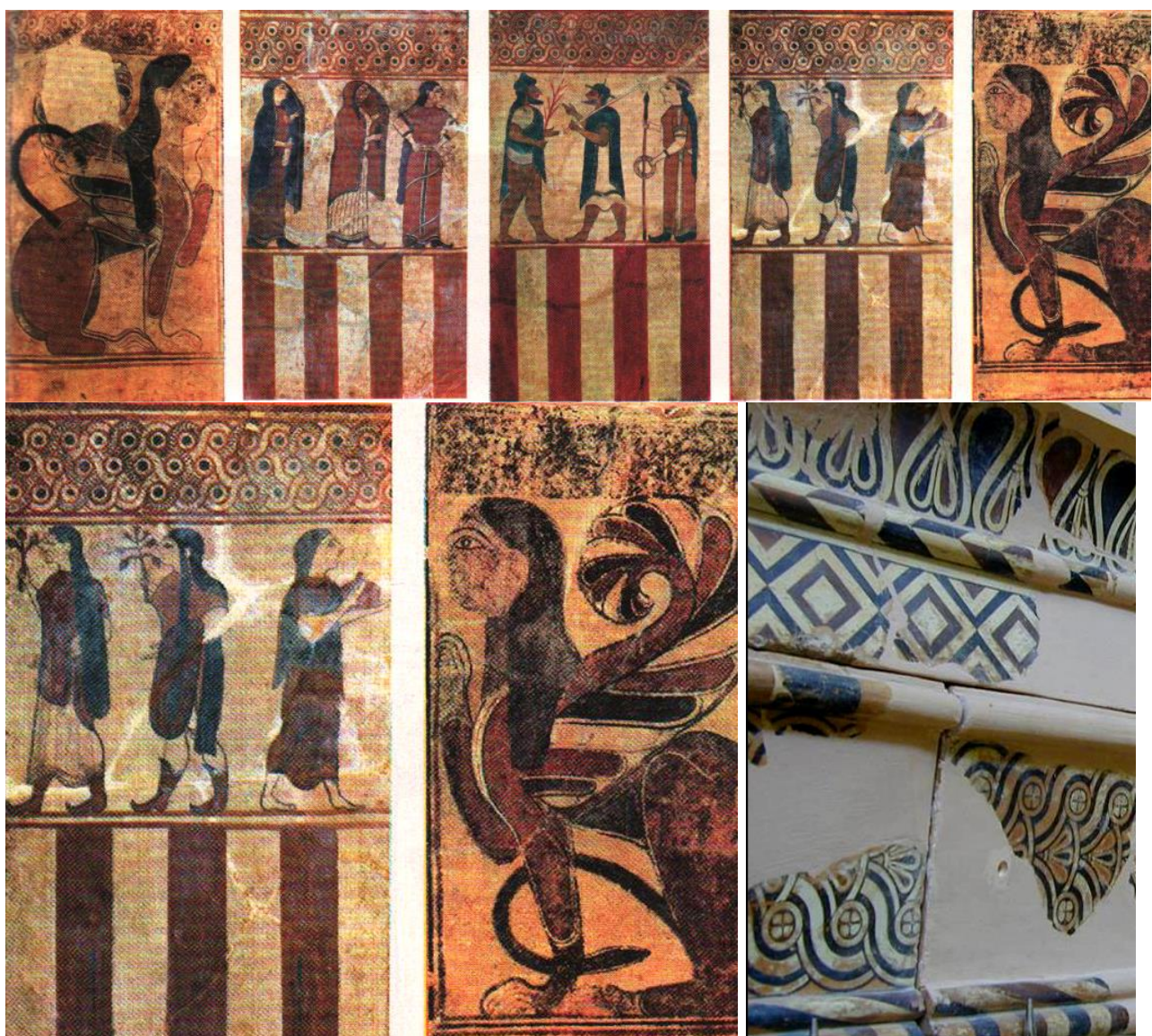

Figure 43. Slabs Boccanegra. London, British Museum.General and Details. The Comparison with the Minute Decorations Derived from the Greek World from the Pediment of the Treasure of Gela (Archaeological Museum at Olympia). Details of the Decorations Paintings of the Mouldings

Source: Negri Arnoldi, F. 1968. Storia dell'Arte [History of Art], Vol. I, Milano, Fabbri. Editori. Photograph by G. Ciotta, 2008.

Prevalent topics of murals are scenes with great figures, often with animals and joyful moments of real life: banquets, dances, games, treasure hunts, fighting. Here are used, as in the Aegean and Cretan world in particular, fewer colours but lively and at odds with each other, often complementary, primary colours, and also that they create a pleasant effect over that brisk: red, yellow, blue (the latter in short fields because rare), and green, in addition to white and black. Warm tones prevail, from red to yellow, and even dark contour lines, black, are very clear. The figures, according to oriental use, the feminine ones are clear, and the dark ones are masculine, almost always represented with a three-quarter bust, and face in profile, but with an eye in front, as in the Egyptian and Aegean world.

In the oldest paints the colour is applied directly on the walls of Tuff; later on a layer of plaster, which sometimes ran a brief sketch, but it definitely wasn't a real "fresco" as described by Vitruvius in Book VII of his De Architectura. Among the most ancient murals of Tarquinia are those of the tomb of the Bulls (mid- $6^{\text {th }}$ Century B.C.), where the subject of Achilles approaches the ambush to the son of 
Priam, Troilo, who proceeds to horse, shows that the reference of the archaic Etruscan repertoire is still that derived from Greek mythological themes painted on vases, such as schematic style, influenced by the Ionian vase painting.

In addition, there is the purely architectural motif in polychrome marble slabs feints or alternating red and green tiles and light box, which can also be the only kind of treatment of the walls, as in the case of the first example of a very archaic, and it still appears in many other tombs as a type of decoration of the vault.

In the interior of the graves there are typical motifs of Egyptian tombs and smoother and imaginative motifs of Cycladic and Cretan art. Here too, as in the Egyptian world, you find a composition that adapts to architecture, and scans regularly surfaces and time, creating a unified, highly chromatic, decorations representing scenes and figures in a real space of symbolism unreal. In particular it should be noted that the ' eardrum ' that you create in the wall, because of the rise in time, almost always a barrel vault very low, often ferocious animals almost always addressed hosts, in pairs, like panthers, lions and leopards, which sometimes bite prey. The painting of the Tomb of Greetings, circa 530-520 B.C., is still guided by the ion, but with taste issues and iconography following Etruscan life and costume by now.

The painting of the Tomb of the lionesses, so named for the presence of two Panthers faced in the tympanum of the back wall, dating back perhaps to the 530 B.C., presents figures a banquet laid on beds, and dancers, and an interesting lower frieze in which small dolphins diving in the water are interspersed with ducks in flight, natural taste. In addition to the Tomb of hunting and fishing (520-510 B.C.), also with painted strong naturalistic, include the Tomb of Baron, always in Tarquinia, and the Tomb of chariots, rear, showing similarities to the attic red-figure vase painting.

The tomb of Leopardi, dated between 455 and 475 B.C., very well preserved, very bright colours both in thick figures in light and dark, which fund Banquet, and in walls and the vault, is very interesting because iconographically show the end for the taste for Ionic's dresses, and on top of that the graffito preparatory drawing. The two big leopards faced stand out decoratively as the time all treated in coloured boxes from geometry that follows the slope of the roof. And with regard to the represented wild beasts, it must be remembered that the leopard is the animal that always accompanies Dionysus, the Greek God, who represents fertility and nature.

The Etruscan tomb painting of the second half of the $4^{\text {th }}$ Century B.C., still shows the subjects in the Greek myth which often accompany images of demonic Etruscan deities, which progressively change the character from festive to dark and disturbing. The influence of Greek art is usually weak and late, except the famous sarcophagus of the Amazons found at Tarquinia, considered one of the highest and singular episodes of Etruscan painting. In the Hellenistic period the Etruscan painting is again sensitive to the Greek influences, as they show many tombs of Tarquinia, including the two Tombs of Orcus (between the $3^{\text {rd }}$ and $2^{\text {nd }}$ Century B.C.), the painting of the famous Tomb 
of the Shields (mid- $3^{\text {rd }}$ Century B.C.), with Banquet Scene, leaning against a Cretan-wave range.

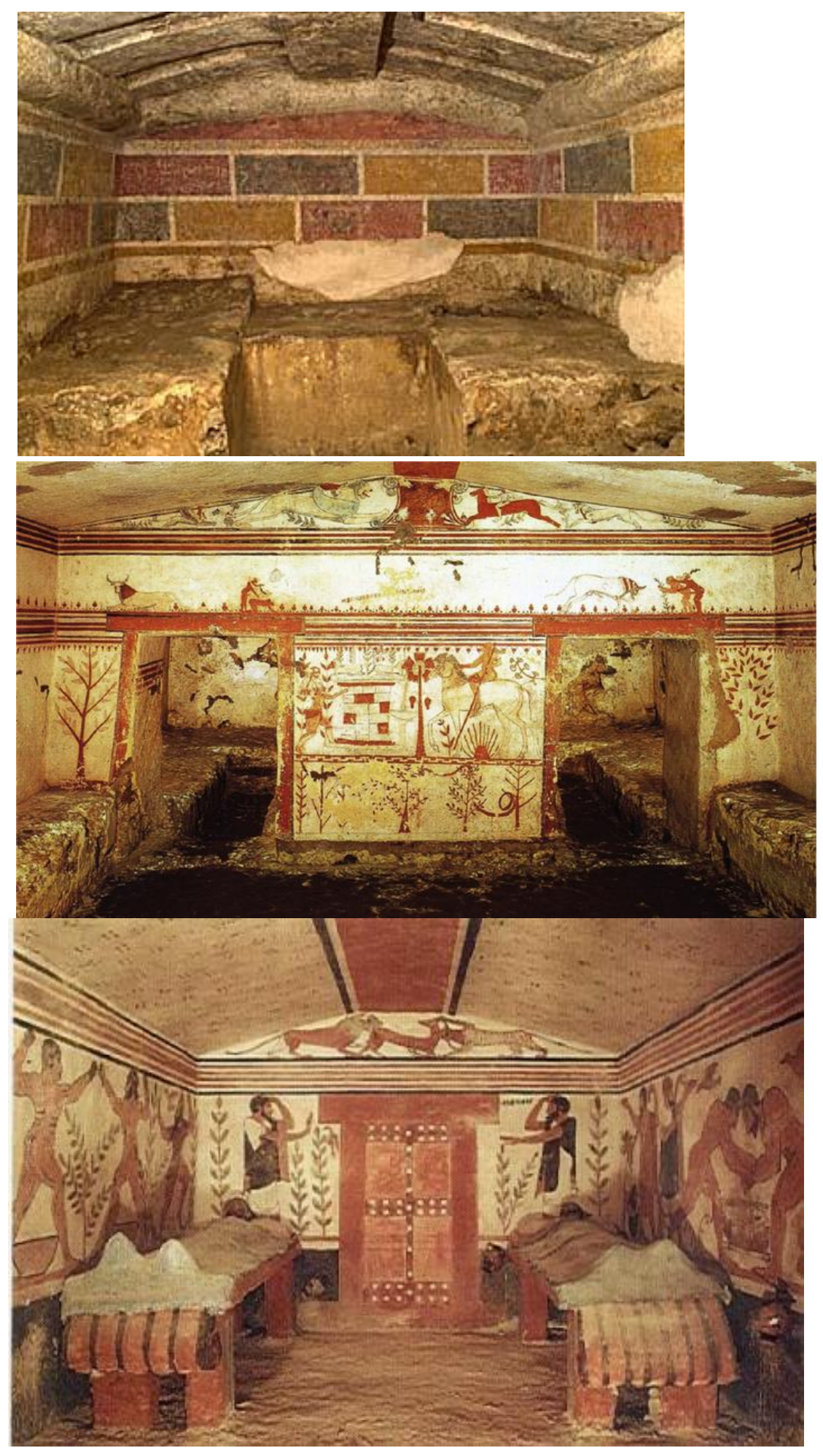




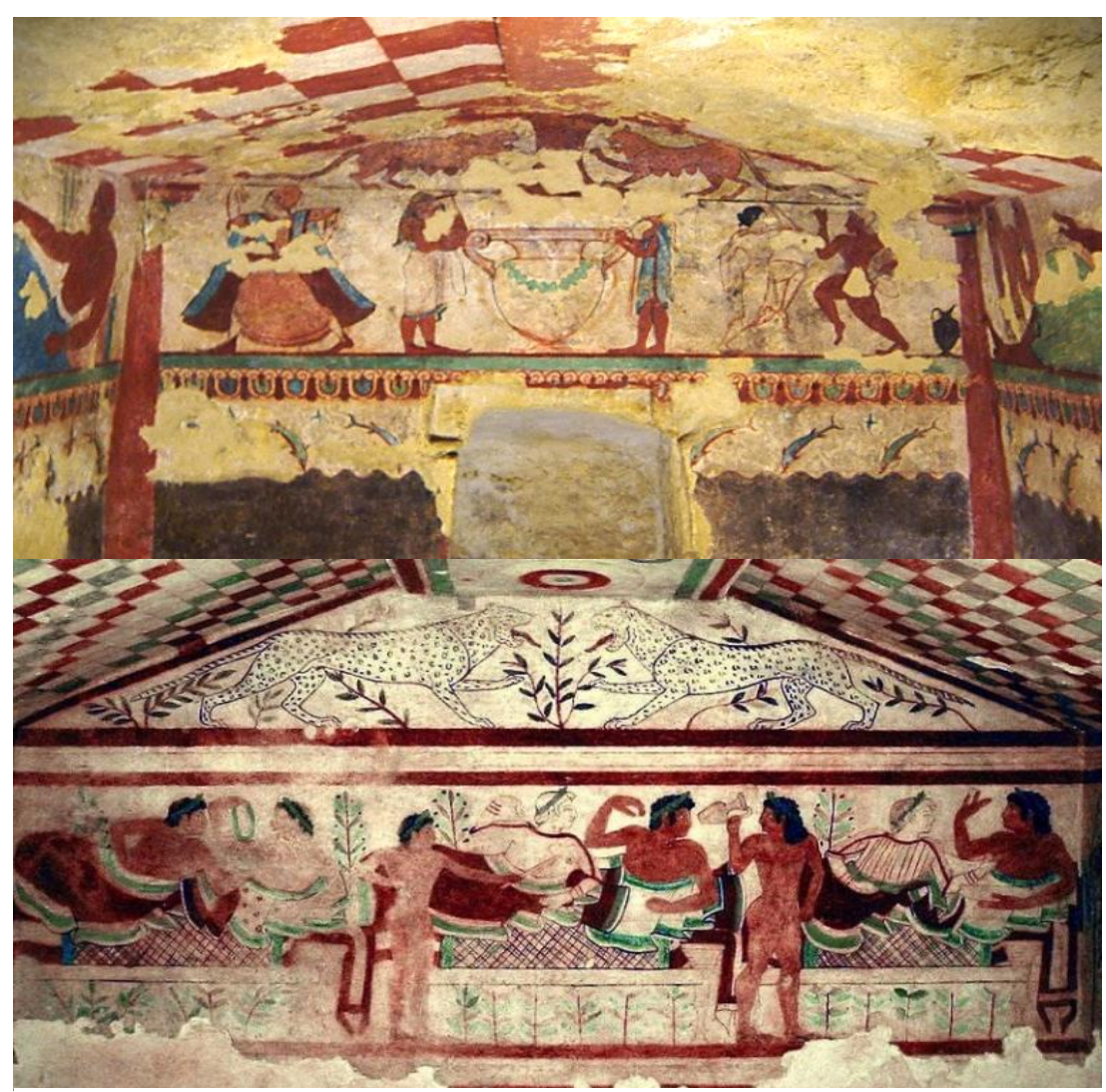

Figure 44. Top, Faux Marble Slabs Tomb, Extended to All the Walls (below, in sequence) Tomb of the Bulls. Tomb of Greetings: The "Wrestlers". Tomb of the Lionesses. Tomb of Leopardi

Source: (Photographs) Negri Arnoldi, History of Art, Vol. I, Milan, Fabbri Editors, 1968. https://tinyurl.com/yc2vg2yv.

Colors and Decorative Features in the Roman Civilization: Use and Characters

From the Eastern world and Greek, whose painters also work among the Romans, this practice spreads across the Mediterranean and arrived in Rome, which has already been affected and in continuity with the nearby Etruscan culture, as evident from wall treatments, especially of the graves. In Rome earn great fortune and spread, even to the characteristic to be a not unimportant element of social distinction, and often political, of the client. And from Rome to the wider world as that of summer homes of Pompeii Herculaneum and Campania in General.

The Roman world also uses a lively polychrome, and decorative features increasingly complex following a remarkable evolution, and different relationships with the architecture (from simple sheet music to draw on the walls, painted fake and complex architectures at fictions plants of gardens with flowers fruits and animals such as the House of Livia on the Palatine, or paintings incorporated into the wall. These decorative types are well described by Vitruvius in his De Architectura Libri Decem, in chapter V "of reason of painting in gli edificj", that there is even to describe painting techniques and colors used. 


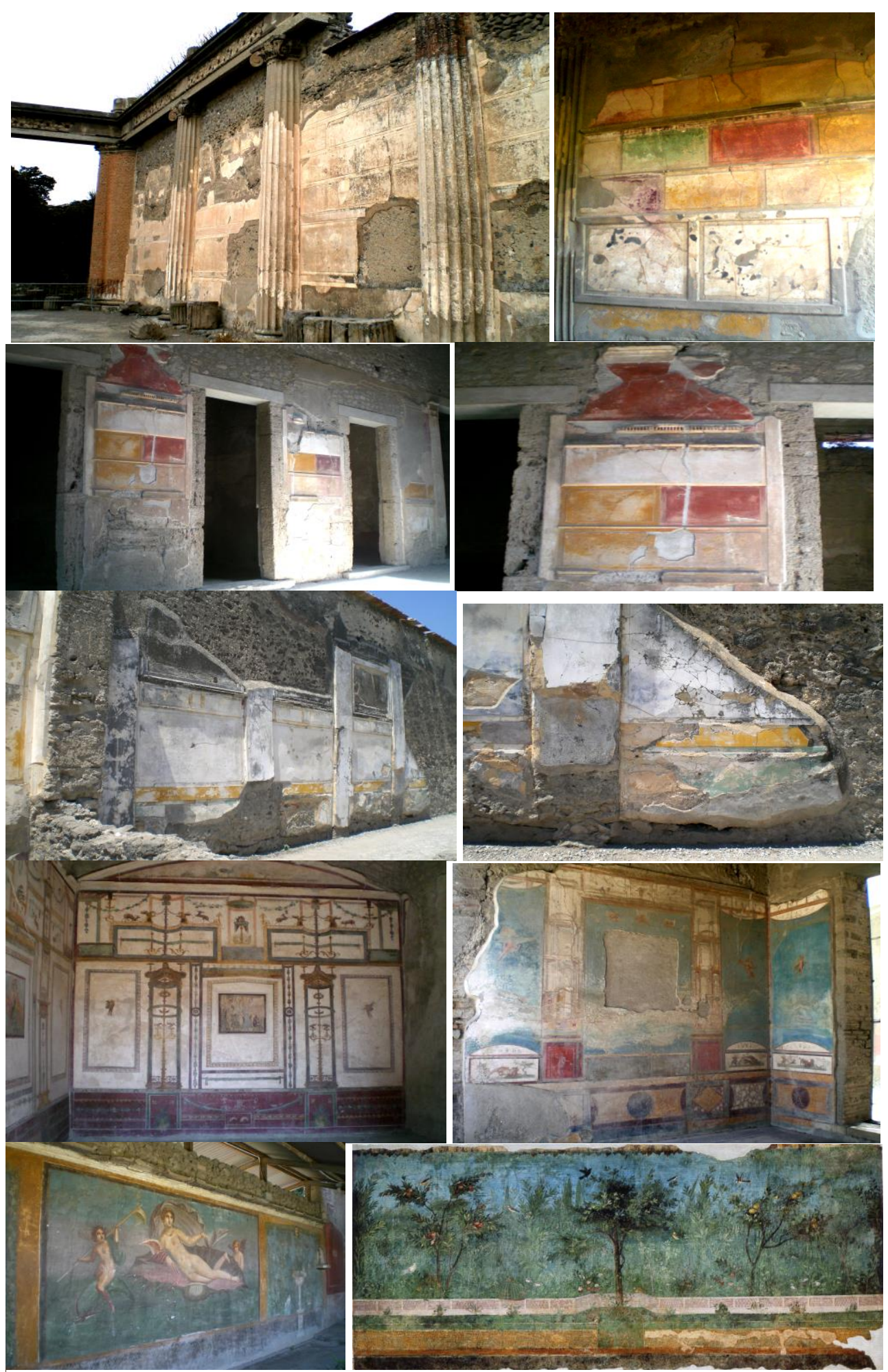

Figure 45. Pompei (Top) Basilica. Current State (to the Right and Below) House of Sallust. Details of the Atrium and an Oecus (Under) Casa del Fauno and Other Types of Decorative II - III - IV Style, including the House of Venus in the Shell, and the House of Livia on the Palatine Hill in Rome Source: Photographs by Author. 
A valuable reference for both understanding and typological and iconographic interpretation than preserved this archaeological heritage and the painted facades that over the centuries have perpetuated these decorative patterns, particularly since the Renaissance, in the treatment of the exterior architecture, which still remain to mark the historic building heritage.

The XIX Century Iconographic Documentation: The Surveys

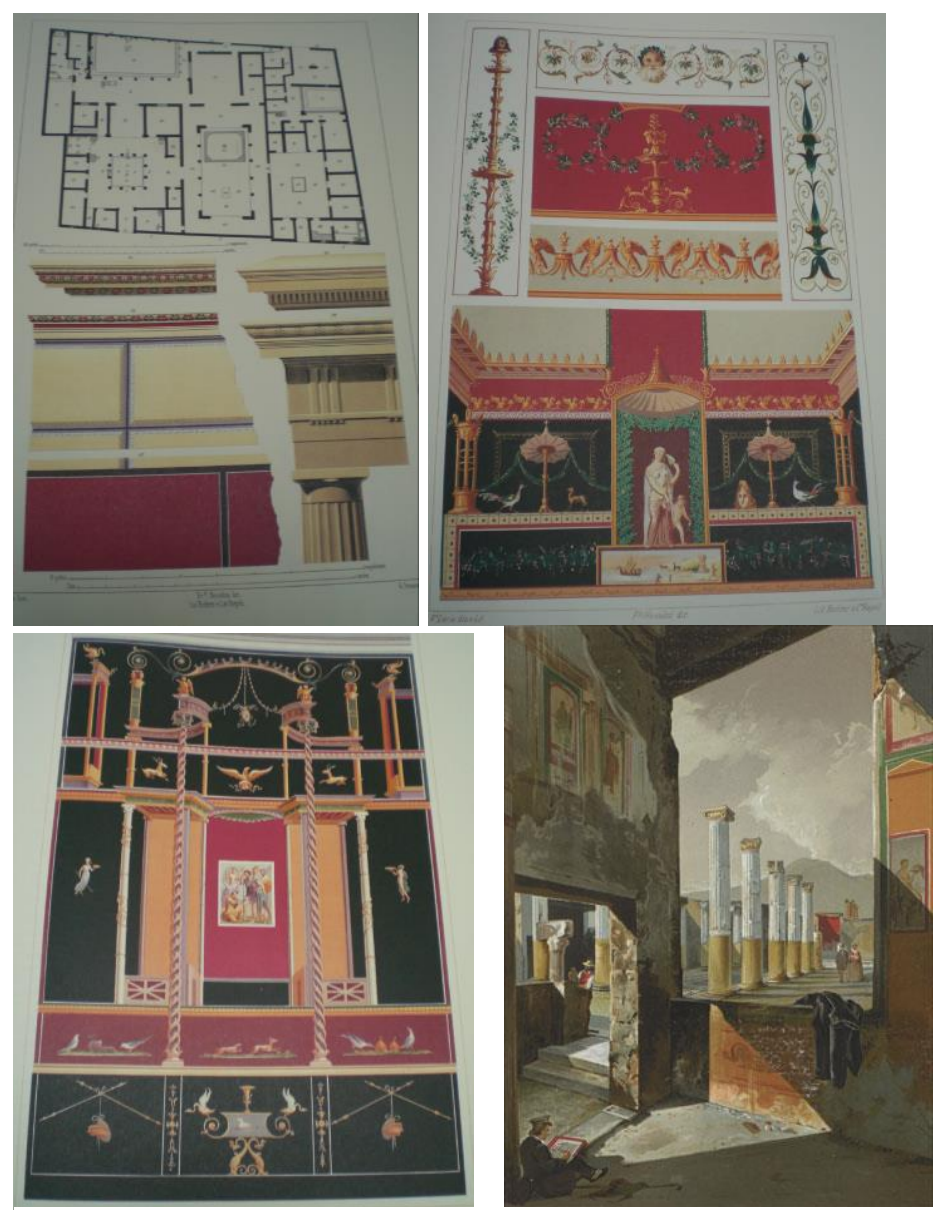

Figure 46. A Valuable Iconographic Documentation, both for the Number of Houses Measured, both in the Relief of Colors, but also Attentive to the Landscape Aspect, is that Produced by the Niccolini Brothers, Published in: Niccolini, F., Niccolini, F., Le case ed i monumenti di Pompei. Disegnati e descritti [Homes and Monuments of Pompeii. Designed and Described] (Reissued anast. 1854-1896) Sorrento (NA), Franco Di Mauro

Source: Photographs by Author. 


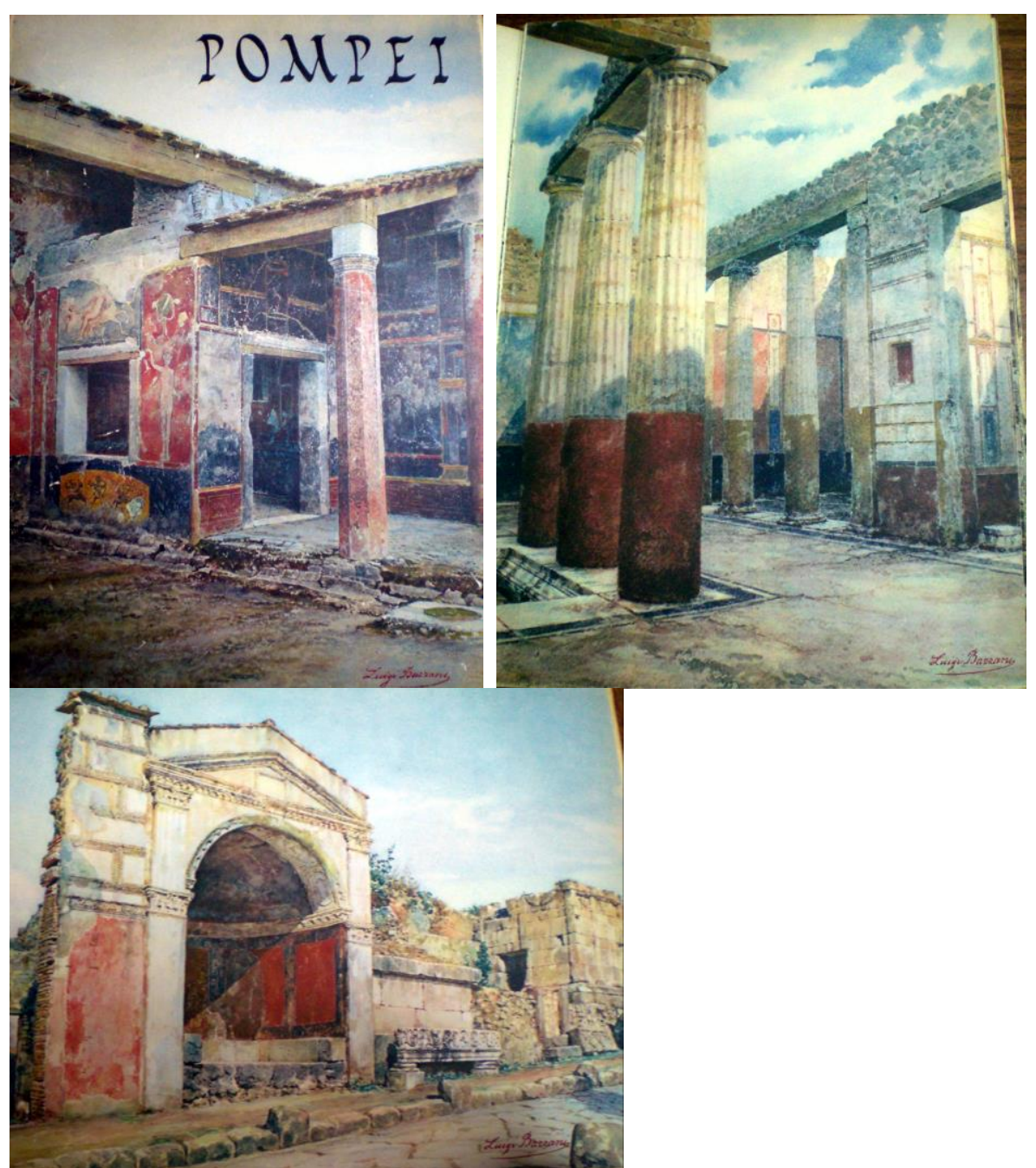

Figure 47. The Watercolors by Luigi Bazzani (In: Maiuri, Pompeii, 1928); those also Constitute a Very Important Representation for the Documentation of Environmental Character

\section{Colors and Coloring Matters}

The original colors were found in sites in their vials, along with the frescoes preserved, as well as at the time of the eruption, and analyzed by Selim Augusti and edited in: Pompeiani colors, De Luca Editor, Rome, $1967 .^{13}$

13. S. Augusti, I Colori Pompeiani (De Luca Editore, Roma, 1967). 

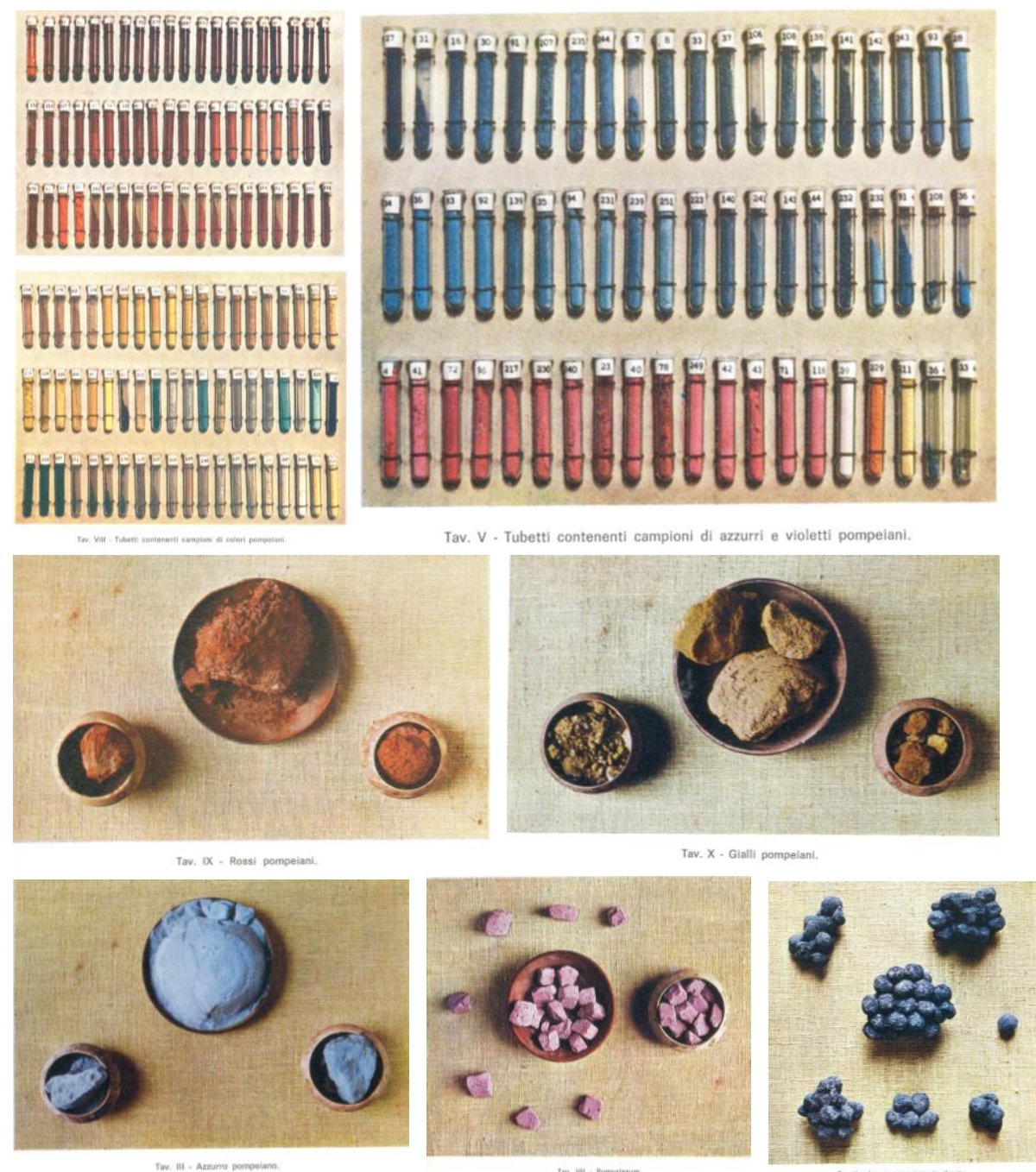

Figure 48. Pictures of Vials and Color Samples of Pompeii taken from: Augusti, S. Pompeian Colors, 1967 (From the Top) Tav. VIII - Tubes Containing Samples of Pompeian Colors. TAV. V-Tubes Containing Samples of Blues and Violets Pompeians. TAV. IX - Pompeian Red. TAV. X-Yellow Pompeians. TAV. VIIPurpurissum-Tav. II-Light Blue Pompeian in Beads. TAV. III - Light Blue Pompeian

\section{Conclusions}

As extensively explained for the different cultures of the Mediterranean world, the common themes and the relative modes of representation are now compared with respect to:

- The Egyptian Word and Cycladic civilization and Cretan.

- The comparison between the architectural decoration from Mesopotamia and Egypt, or from Babylon and Crete

- The artistic relation between Persian Empire and Greek word 
- The Oriental word and the islands (Sicily, Sardinia) and southern Italy

- The Phoenician Culture and Egyptian, Assyrian, Hittite and Cretan cultures

- The relations between Crete, Egypt, and Syria

- The frescoes from Knossos and the low relief from Egypt

- The spread of Cretan art or Egyptian artifacts in Mycenaean area

- The Etruscan civilization with Greek, Phoenician cultures or Egyptian culture

First Criticism Synthesis: the Stucco Decoration Type, then Painting, Polychrome Marble Slabs; or just Feigning Painted

A Treatment Modality of the Exteriors Recurring over Time in Mediterranean Countries

Analysis of wall treatments so far made leads us to record the occurrence of many decorative features, and especially the colors, almost always a few simple but lively, often the primary colors and complementary colors. One of the most interesting attitudes, readable since the ancient times, significant attitude, in painting, 'mimesis' real architecture, which is fundamental and recurrent, always is that of a type of apparatus that appears across the centuries and cultures of the Mediterranean, seen from the preserved widely.

This is the architectural motif, polychrome marble slabs-decorative faux stucco, then painted, used to mimic high quality materials, to cover both inside and outside of buildings; common theme that we find from the Aegean world, from Greece and Macedonia (Pella), tombs, the Roman world and, in particular, how preserved or documented at Pompeii and Herculaneum, which coincides basically with the first style of Roman painting described by Vitruvius. ${ }^{14}$

In particular, the interest in decoration type I style, developed by the $2^{\text {nd }}$ Century B.C. until the beginning of the A.C., from 150 B.C. until 80 B.C., called "faux marble incrustation", is motivated by the architectural objectives: that is, not only to feign masonry equipment materials, but to "do architecture". Joyful and colorful architecture, which creates on the walls stucco encrustations worked in relief, then painted as horizontal slabs of marble, rusticated mock architectural elements of horizontal and vertical partition walls as columns, columns, pilasters, cornices, capitals and indented, smooth in few recurring red, ochre, and vivid colours: blue, green and purple, and then black and white. This is found in many examples, from the famous ones of Pompei of the Basilica, the House of Sallust, the House of the Faun, and many other buildings. ${ }^{15}$

Another variant with more decorative purpose is the creation in painted color boxes, which somehow pertain to polychrome stone materials. Also, that even more decorative, is variegated marble painting representation, especially

14. M. P. Vitruvio, "I Dieci Libri Dell'architettura," (trans. and comm.) Daniele Barbaro, with an Essay by M. Tafuri (Milano: Il Polifilo, 1987); P. Gros, Vitruvio, De Architectura (trans. and comm.) A. di Corso and E. Romano (Torino: Einaudi, 1997).

15. Ibid. 
in the base of the wall, as in Pella, but even more in Crete, in the throne room of the Palace of Knossos; a type that will meet great fortune over the centuries, to form sometimes very high plinths and bases, in painted walls.
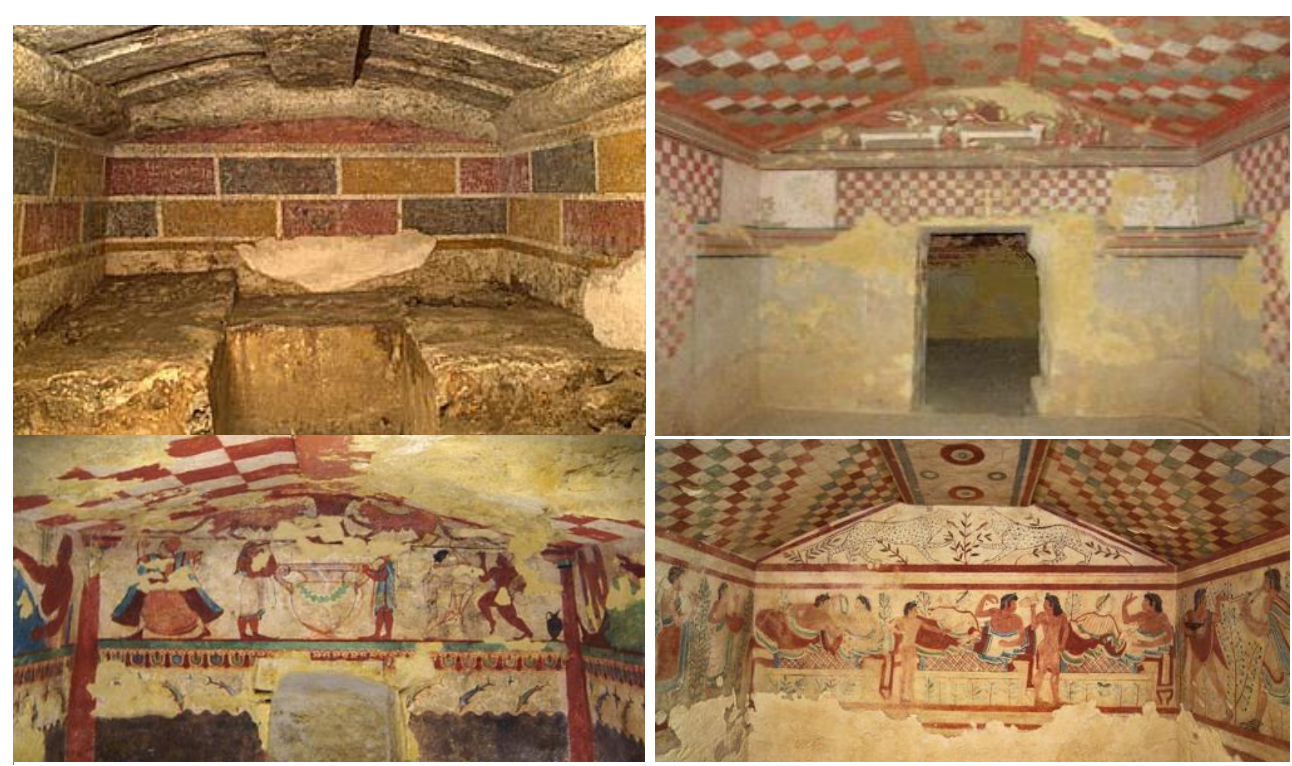

Figure 49. Italy. Etruscan Tombs. Polycrome Slabs Decorations Centuries Pretending Marbles or Decorative Boxes, also in the Vaults, or most definitely Painted. Red, Green, Ocher. Tombs with Artificial Painted Plates; Tomb Bartoccini, Tomb of the Lionesses and Tomb of the Leopards
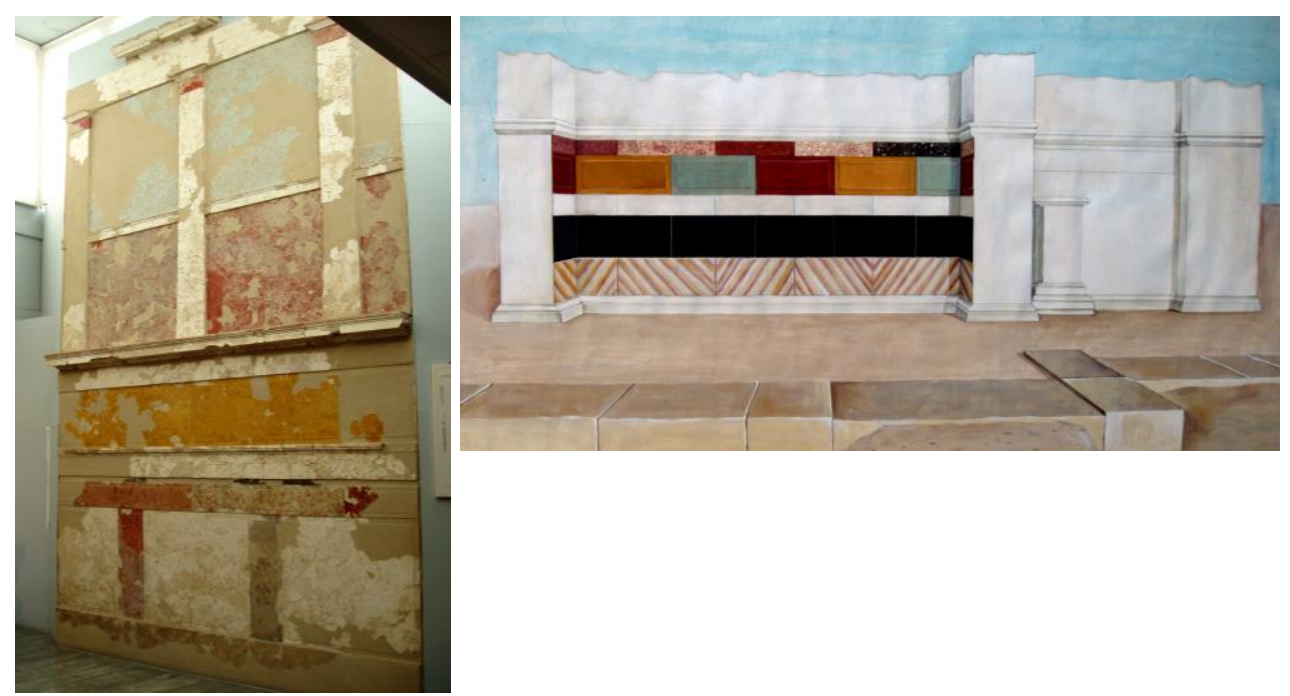

Figure 50. Macedonia, Museum of the Archaeological Site of Pella. Reconstruction of the Façade of a House in Pella in the Time of Philip II (382-336 BC) Simple Architectural Structures, Horizontal and Vertical, and Faux Marble Panels, in Ochre, Wine Red, Brown, Blue and Clear Color False Marble 


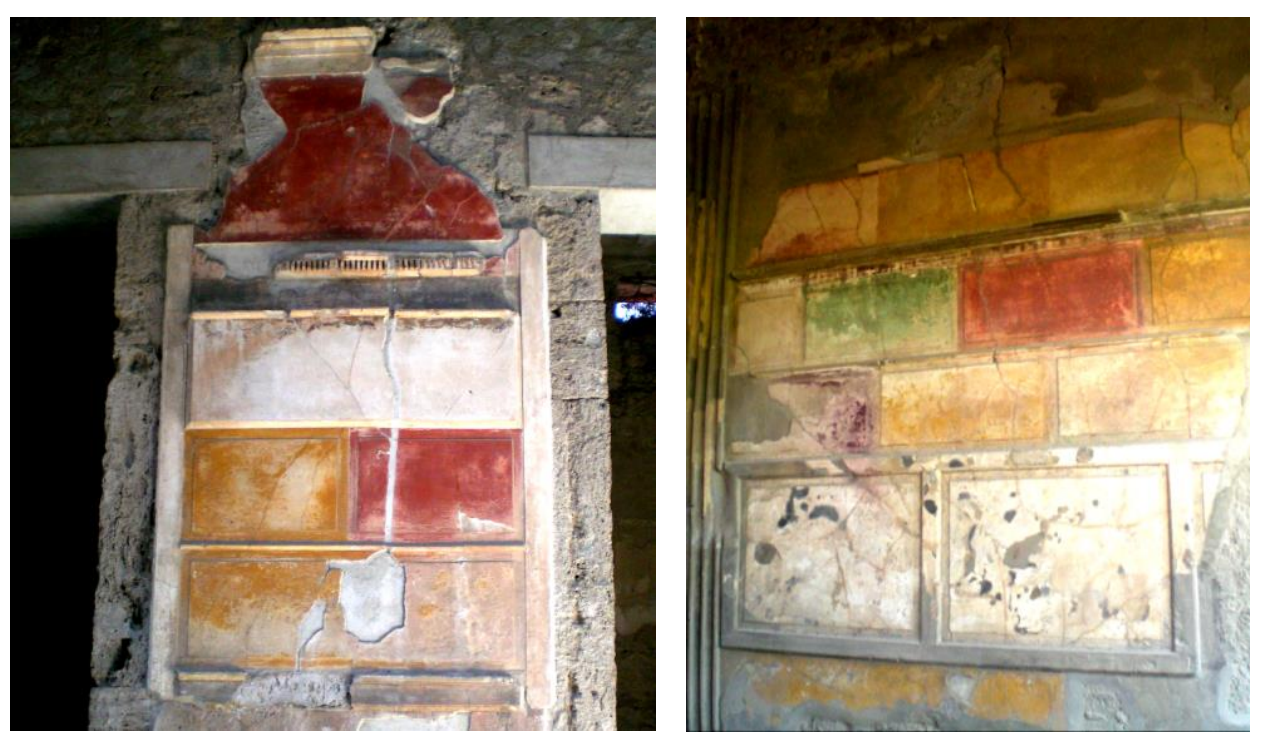

Figure 51. Pompei. Italia. House of Sallustio. For this Building was carried out by the Author of Color Survey, in Situ, with Direct Method, with Samples of Munsel Book of Color

\section{Main Surveyed Colors}

red $10 \mathrm{r} 3 / 10$ but more saturated, tend to $10 \mathrm{r} 3 / 8$ red 10 r 4/12 discoloured ochre 7.5 yr $6 / 8$ green 7.5 gy $5 / 2$ green 10 gy $4 / 2$ darker spots legibles wined dark red $10 \mathrm{rp} 2 / 4$ wined light red $10 \mathrm{rp} 3 / 4$

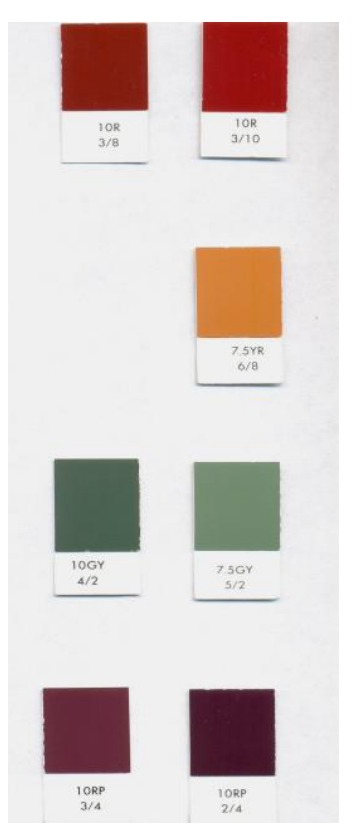




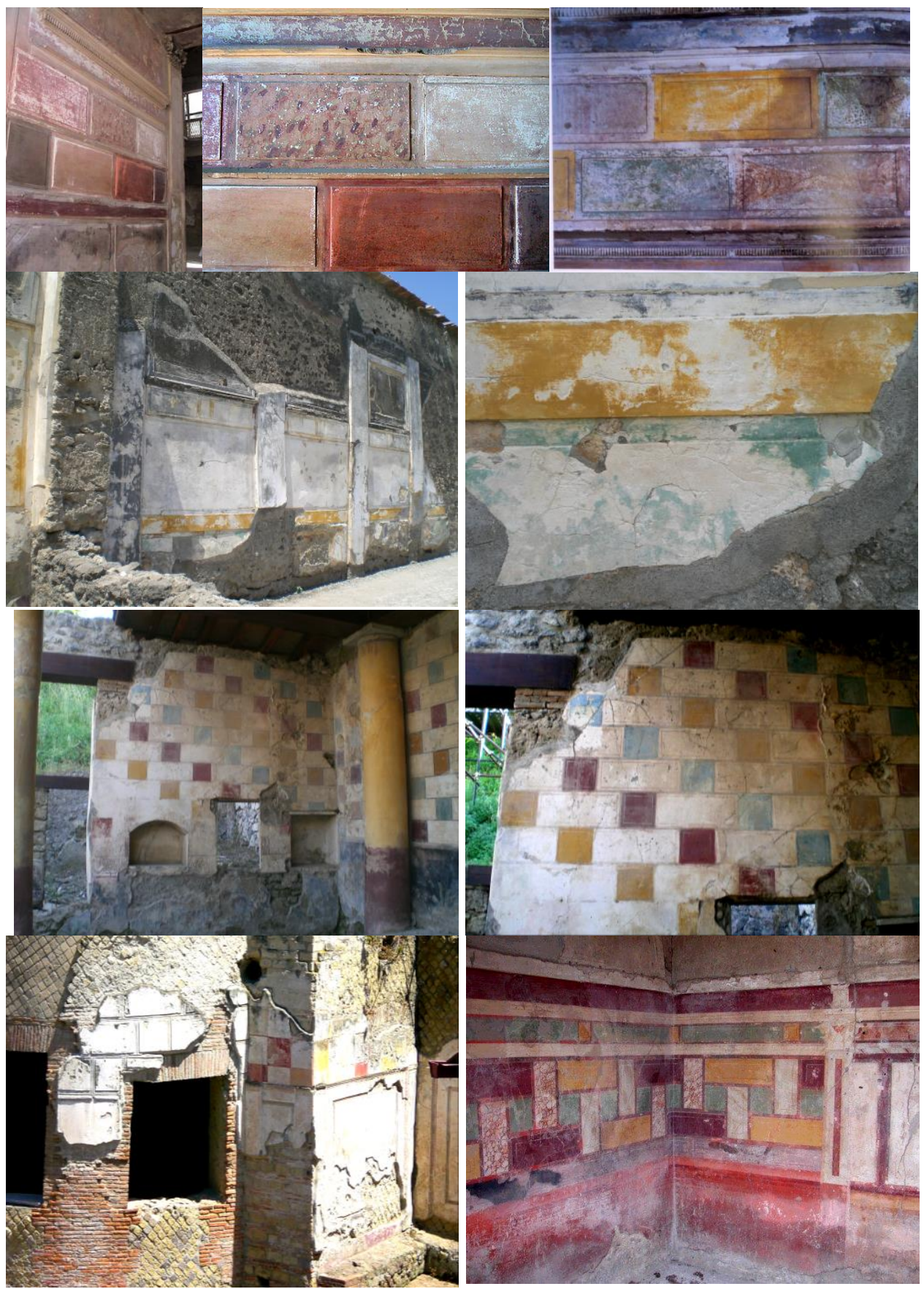

Figure 52. (On the top) House in Ercolano (below) Pompei: House of the Centauro, photos from: Pompei. Paintings and Mosaics, Italian Encyclopaedia, 819-824 (below) House of Fauno. House of Trebius Valens. Building at Porta Marina. House of Cerere 

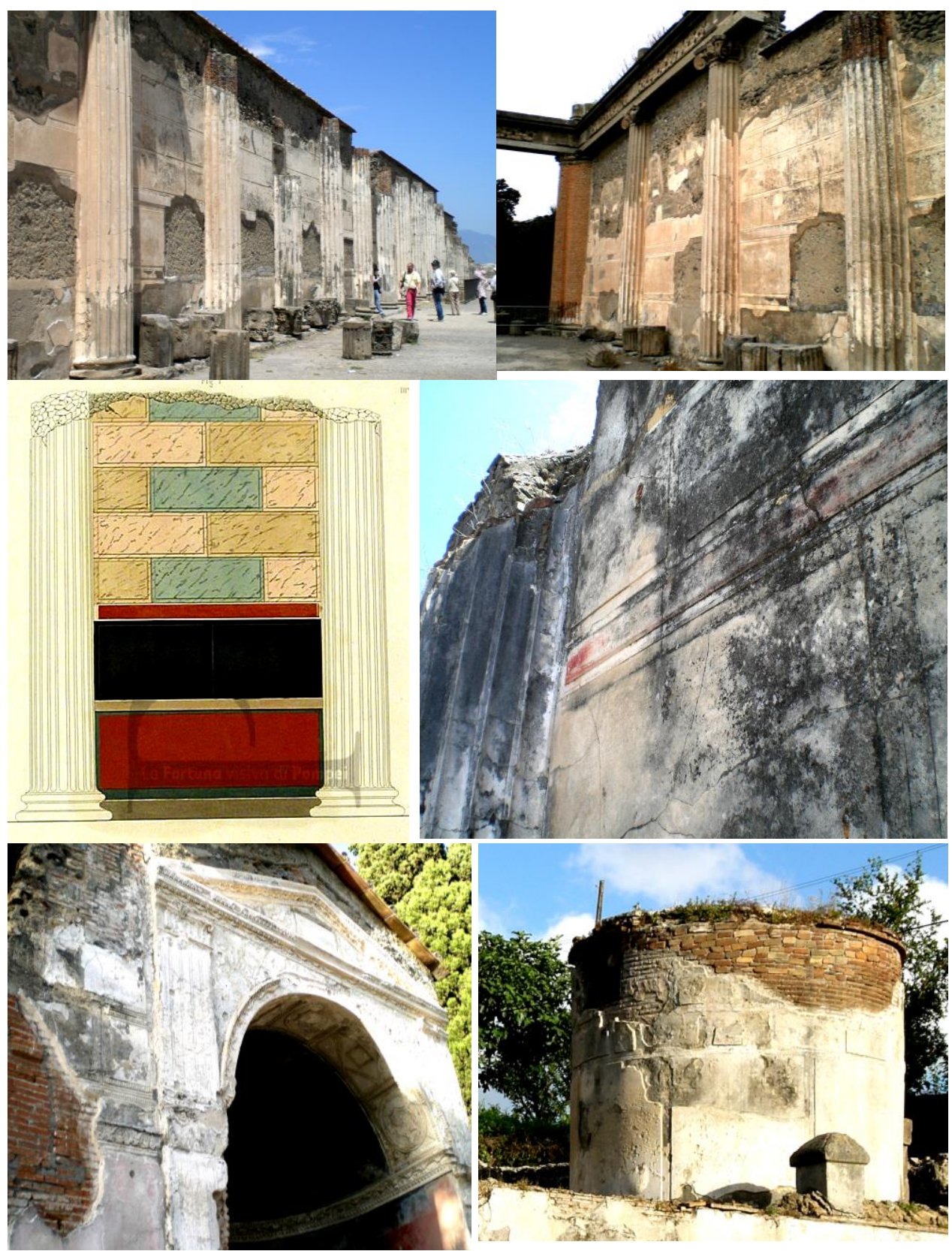

Figure 53. Pompeii. Italy. Basilica (below) Detail of the Relief off. Mazois, in: Les Ruines de Pompéi et mesurées, dessinées parf. Mazois, pendant les années MDCCCIX, MDCCCX, MDCCCXI ..., Paris, 1812-1838 (source: Pompeii sns.it, Pisa Pompeii Visual luck) (under) Esedra tomb and Mausoleum in via dei Sepolcri, stucco sheets coated in fiction of marble 


\section{B - Figures Decoration: Criteria and Representation Modes of the Characters and of the Spatial Insertion of Human Figure in the Various Cultures}

Here you want then waving, just a nod, another attitude, very important, spanning centuries and cultures, which concern the mode of representation of the human figure in ancient times.

Traveling from Egyptian world, and even before, which may appear naïve and lack of experience in the design, but in fact remains in different cultures as it responds to a precise purpose.

A way in which the bust is almost always three-quarters represented, and the face in profile, but with the eye in front, and legs still in profile.

In fact the three-quarter or front bust is fundamental for the identification of the represented person, and of its space, like the legs in profile, which indicate movement, and the face, though in profile, presents the eye in front, which makes the maximum characterization of the represented person.

This mode is widely found in the Egyptian culture, in the Babylonian, in the Cretan culture, and then in the Greek and Etruscan, all civilizations in close contact over the centuries.

Moreover, the figures, according to oriental use, are almost always clear, the feminine ones, and the masculine ones dark.
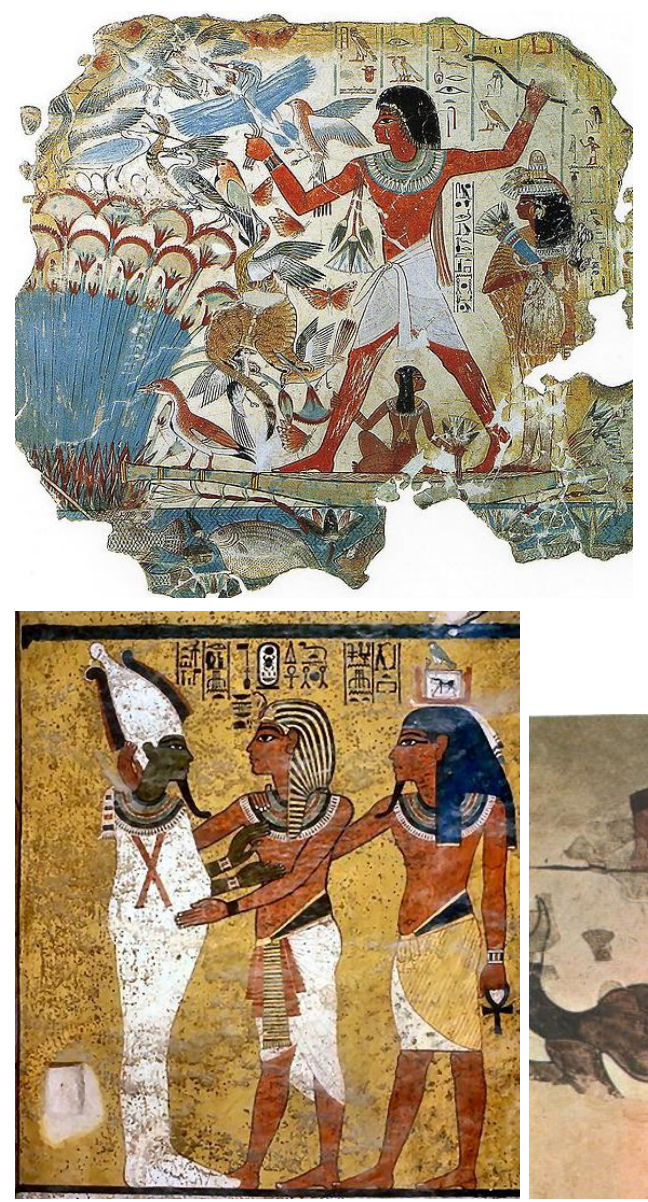
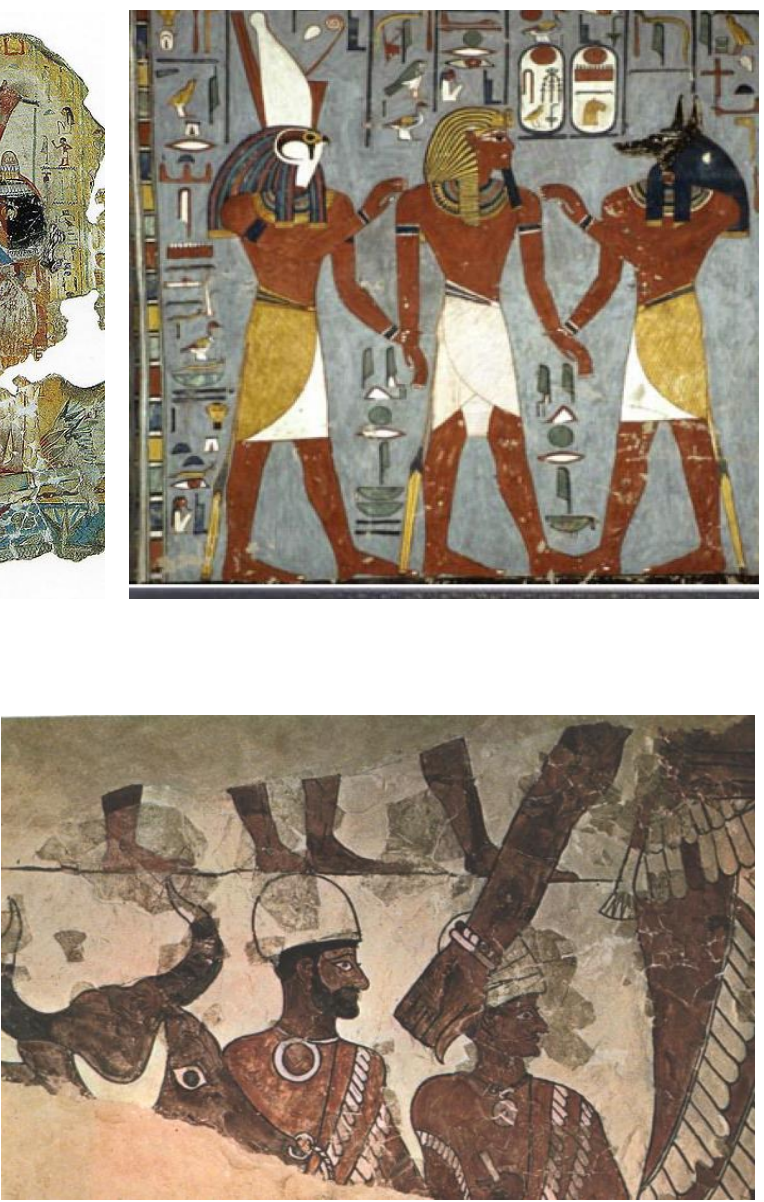


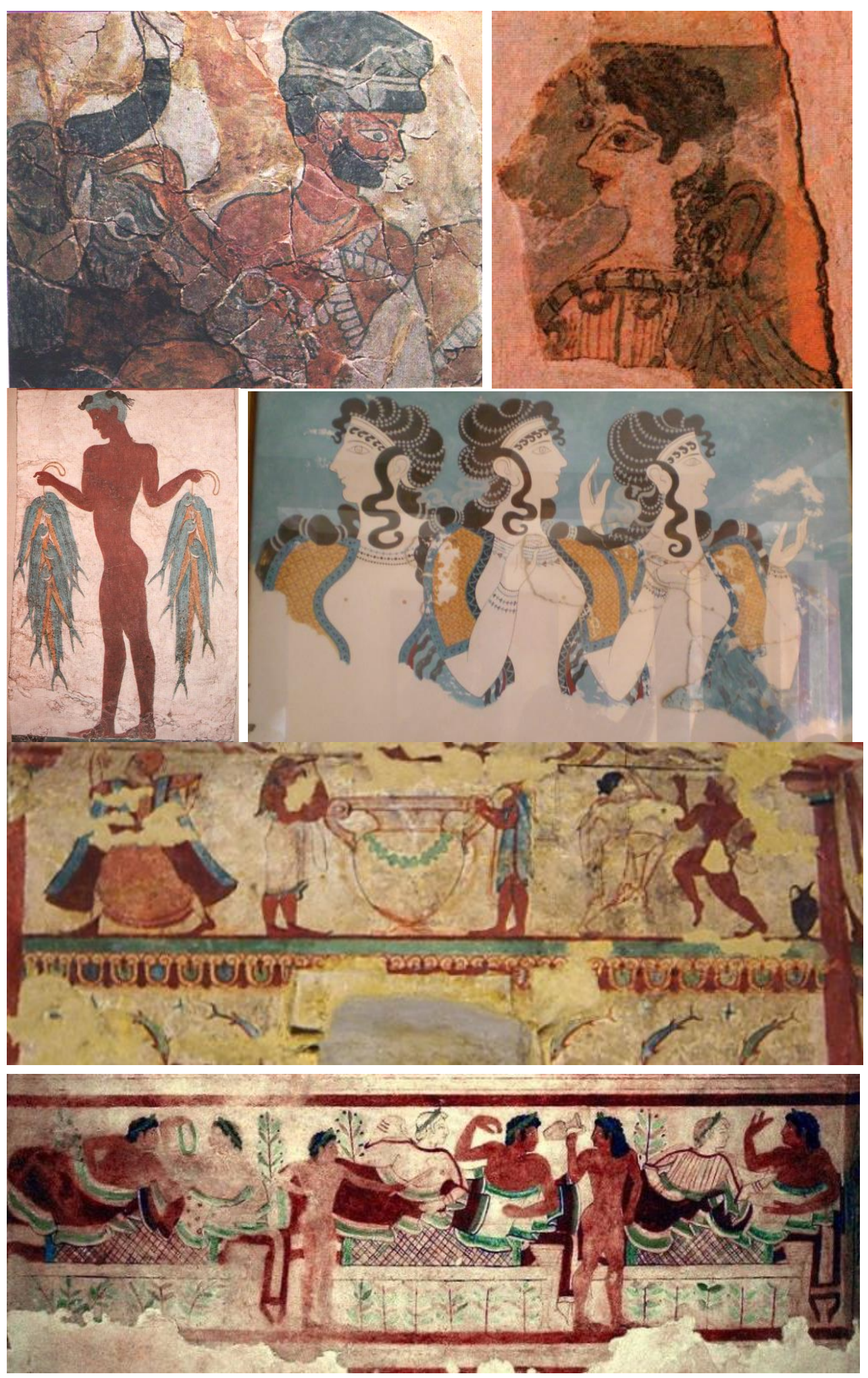

Figure 54. The Human Representation in Different Cultures of the Ancient World 


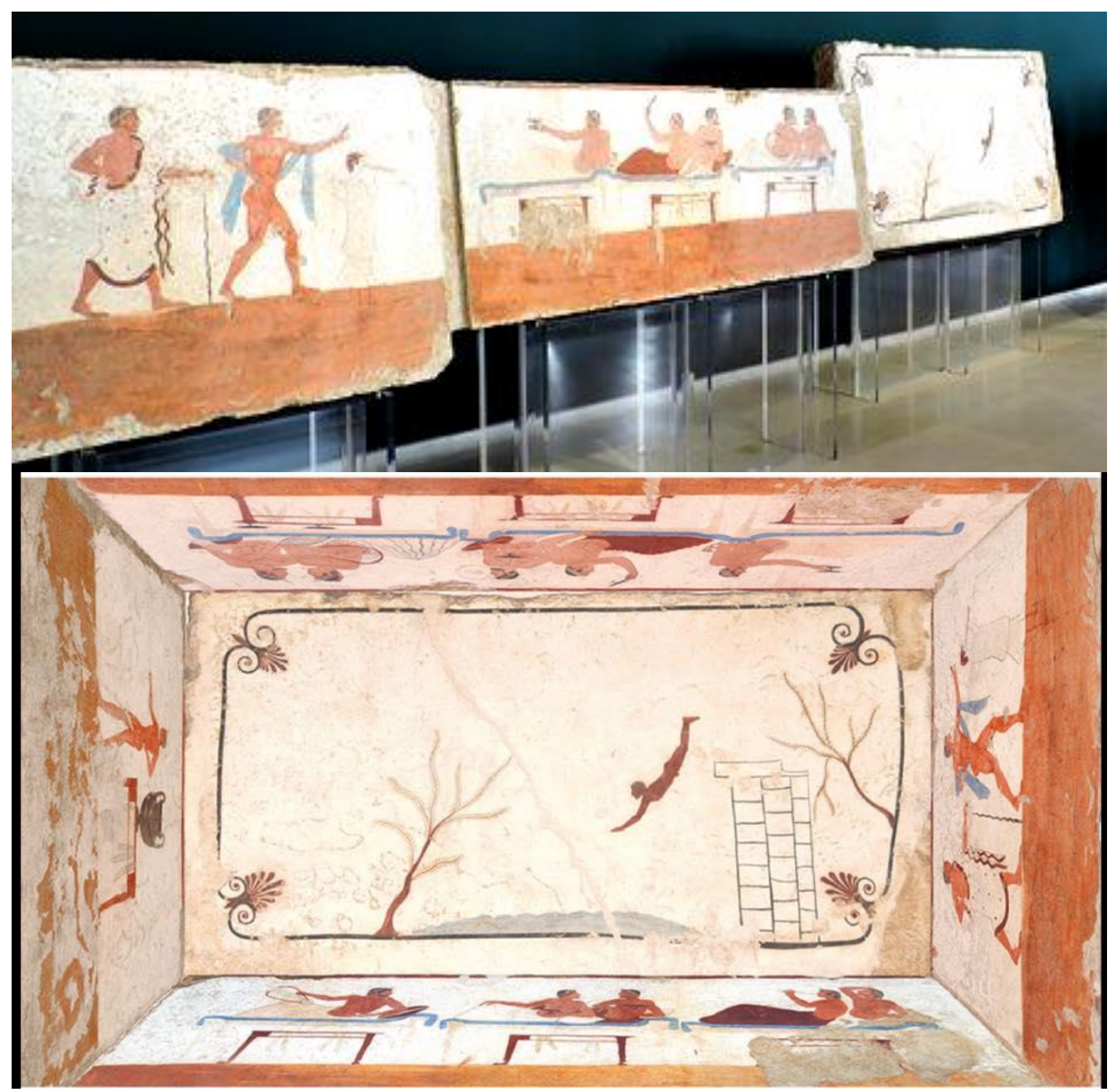

Figure 55. Paestum (Salerno), Magna Grecia. Tomb of the Diver, National Archeologic Museum of Paestum

\section{C - Representations of the Animal World}

Just a mention, instead, to the aspect, of the animals' representation, that at a first recognition is offered to different considerations: for the recurrences in the types of animals represented (those of the Mediterranean and Eastern world) and the relative representative modes, often addressed to a very joyful decorative component. Dolphins in Knossos, in the Queen's Hall; dolphins in Tarquinia, in the Tomb of the Lionesses, together with gazelles. And then symbolic animals like griffins, sacrificial bulls, and above all wild beasts such as leopards, panthers and lionesses. 


\section{D - The Themes}

Also the themes often repeat aspects of life, customs, religiosity, and environmental aspects of the different territories, even very far away. They are above all:

- Religious themes

- Sacrificial themes

- Political and self-congratulatory themes of the men in power

- Daily life themes

- War themes

- Themes on the nature and environment of various peoples

\section{Bibliography}

Augusti, S. I Colori Pompeiani. [Pompeian Colors.] Rome: De Luca Editore, 1967.

Billot, M. F. Recherches aux XVIIIe et XIXe Siècles sur la Polychromie de l'Architecture Grecque, in Paris - Rome - Athènes. Le Voyage en Grèce des Architectes Francais aux XIXe Siècle. [Research in the $18^{\text {th }}$ and $19^{\text {th }}$ Centuries on the Polychrome of Greek Architecture, in Paris - Rome - Athens. The Trip to Greece of French Architects in the $19^{\text {th }}$ Century.] Paris: Catalogo della Mostra, 1982.

Ciotta, A. "L'Interesse per la Policromia dell'Architettura Greca nell'Ottocento Europeo." [The Interest in Polychromy in Architecture in the $19^{\text {th }}$ Century European.] In Colore Architettura, Ambiente. Edited by P. Falzone. Rome: KAPPA, 2008, 158-164.

Ciotta, G. Architetture Egee. Momenti di Culture Variegate e Premesse alla Civiltà Greca. [Egee Architectures. Moments of Varied Cultures and Premises to the Greek Civilization.] Milano: Franco Angeli, 2013.

Coste, P. Monuments Modernes de la Perse. [Modern Monuments of Persia.] Paris: A. Morel, 1867.

Falzone, P. "Colore Architettura Ambiente. Temi e Problematiche." [Color Architecture Environment. Themes and Problems.] In Colore Architettura Ambiente. Edited by P. Falzone. Rome: KAPPA, 2008.

. "In Tema di Paramenti e Rivestimenti del Costruito. Il Motivo a Fasce Bicrome e Policrome. Influssi e Contaminazioni Attraverso il Bacino Mediterraneo.” [In Theme of Building Coatings and Hangings. The Two Colors and Bands. Influences and Contaminations across the Mediterranean Basin.] In Colore e Colorimetria: Contributi Multidisciplinari. Edited by M. Rossi and A. Siniscalco. Firenze: Maggioli Editore, 2013, 504-520.

Gros, P. (ed.) Vitruvio, De Architectura. [Vitruvius, On Architecture.] Translated and Commented by A. di Corso and E. Romano. Torino: Einaudi, 1997.

Hittorf, J. De l'Architecture Polychrome chez les Grecs, ou Restitution Complete du Temple d'Empedocle, dans l'Acropole de Selinunte. [Polychrome Architecture among the Greeks, or Complete Restitution of the Temple of Empedocle, in the Acropolis of Selinunte.] Paris: Firmin Didot, 1851.

Kugler, F. Uber die Polychromie der Griechischen Architektur und Sculptur, und ihre Grenzen. [On the Polychromy of Greek Architecture and Sculpture, and its Borders.] Berlin: G. Gropius, 1835. 
Maiuri, A. Pompei. (Con Acquarelli di Luigi Bazzani.) [Pompei. (With Watercolors by Luigi Bazzani.)] Novara: Istituto Geografico De Agostini, 1928.

Mora, L., P. Mora and G. Zander. "Coloriture e Intonaci nel Mondo Antico." [Colorings and Plasters in the Ancient World.] In Bollettino d'Arte, Supplemento al $N^{\circ} 35-36$. Rome: Istituto Poligrafico e Zecca dello Stato, 1986.

Negri Arnoldi, F. Storia dell'Arte. [History of Art.] Milan: Fabbri Editori, 1968.

Niccolini, F. and F. Niccolini. Le Case ed i Monumenti di Pompei. Disegnati e Descritti. [The Houses and Monuments of Pompeii. Designed and Described.] Napoli: s.n., 1862.

Papaioannou, Y. and Y. Skouroyannis. Santorini. Athens: Ed. Ben. Issaias \& Co, 1977.

Quatremere de Quincy, A. C. Le Jupiter Olympien ou de l'Art de la Sculpture Antique, Considéré sous un Nouveau Point de Vue; Ouvrage qui Comprend un Essai sur le Gout de la Sculpture Polychrome. [The Olympian Jupiter or the Art of Ancient Sculpture, Considered under a New Point of View; Book that Includes an Essay on the Taste of the Polychrome Sculpture.] Paris: Firmin Didot, 1815.

Semper, G. "The Origin of Polychromy in Architecture." In An Apology for the Coloring of the Greek Court. Edited by J. Owen. London: Crystal Palace Library and Bradbury \& Evans, 1854.

Valavanis, P. The Acropolis through its Museum. Athens: Kapon Edition, 2014.

Vitruvio. "I Dieci Libri Dell'architettura." [The Ten Books of Architecture.] Translated and commented by Daniele Barbaro, with an Essay by M. Tafuri. Milano: Il Polifilo, 1987.

Zander, G. "La Coloritura Degli Edifici e l'Ordine Architettonico." [The Coloring of Buildings and the Architectural Order.] In Intonaci, Colore e Coloriture nell'Edilizia Storica, Atti del Convegno di Studi, Supplemento al n. 35-36, Bollettino d'Arte. Rome: Istituto Poligrafico e Zecca dello Stato, 1986, 25-29. 
